\title{
Performing Anti-Catholicism in Christopher Marlowe's Doctor Faustus
}

\author{
by
}

Nirpjit Bassi

A thesis submitted to the Faculty of Graduate and Postdoctoral Affairs in partial fulfillment of the requirements for the degree of

Master of Arts

in

History

Carleton University

Ottawa, Ontario

(C) 2012, Nirpjit Bassi 
Library and Archives

Canada

Published Heritage

Branch

395 Wellington Street

Ottawa ON K1A ON4

Canada
Bibliothèque et

Archives Canada

Direction du

Patrimoine de l'édition

395 , rue Wellington

Ottawa ON K1A ON4

Canada
Your file Votre référence

ISBN: 978-0-494-93529-3

Our file Notre référence

ISBN: $978-0-494-93529-3$
NOTICE:

The author has granted a nonexclusive license allowing Library and Archives Canada to reproduce, publish, archive, preserve, conserve, communicate to the public by telecommunication or on the Internet, loan, distrbute and sell theses worldwide, for commercial or noncommercial purposes, in microform, paper, electronic and/or any other formats.

The author retains copyright ownership and moral rights in this thesis. Neither the thesis nor substantial extracts from it may be printed or otherwise reproduced without the author's permission.
AVIS:

L'auteur a accordé une licence non exclusive permettant à la Bibliothèque et Archives Canada de reproduire, publier, archiver, sauvegarder, conserver, transmettre au public par télécommunication ou par l'Internet, prêter, distribuer et vendre des thèses partout dans le monde, à des fins commerciales ou autres, sur support microforme, papier, électronique et/ou autres formats.

L'auteur conserve la propriété du droit d'auteur et des droits moraux qui protege cette thèse. $\mathrm{Ni}$ la thèse ni des extraits substantiels de celle-ci ne doivent être imprimés ou autrement reproduits sans son autorisation.
In compliance with the Canadian Privacy Act some supporting forms may have been removed from this thesis.

While these forms may be included in the document page count, their removal does not represent any loss of content from the thesis.
Conformément à la loi canadienne sur la protection de la vie privée, quelques formulaires secondaires ont été enlevés de cette thèse.

Bien que ces formulaires aient inclus dans la pagination, il n'y aura aucun contenu manquant. 
The Department of History recommends to the Faculty of Graduate and Postdoctoral Affairs acceptance of the thesis

\title{
Performing Anti-Catholicism in Christopher Marlowe's Doctor Faustus
}

\author{
submitted by \\ Nirpjit Bassi, B.A. Hons. \\ in partial fulfilment of the requirements \\ for the degree of Master of Arts
}

David M. Dean, Thesis Supervisor

Dominique Marshall, Chair

Department of History

Carleton University

24 May 2012 


\section{Abstract}

This thesis offers an analysis of Catholics and Catholicism in Christopher Marlowe's tragedy Doctor Faustus. It begins with an overview of the historiography of the English Catholic community and Marlowe's stage-play world. The thesis then examines the "A and B" textual versions of the play and offers an analysis of a performance of Doctor Faustus at the Globe Theatre in London in August, 2011. Through Doctor Faustus, Marlowe represents Catholicism as spiritually powerless yet politically dangerous: a theme which appears in other literature of the Elizabethan period. Analyzing the performative possibilities of the play shows that these negative representations of Catholics can be diminished or enhanced depending on dramaturgical choices. The Globe theatre's production of Doctor Faustus reflected the religious tensions found in the text; although Doctor Faustus contains anti-Catholic language and images, this remains only one part of Marlowe's larger representation of the religious ambiguities of the Elizabethan period. 


\section{Acknowledgements}

I would like to begin by thanking Joan White for all of her wonderful help these past two years. Thank you Joan for your support during my thesis defense and for all the incredible things that you do for this department. I would also like to thank my supervisor, David Dean, for his guidance, patience and support with my research, as well as all of his words of encouragement. Thank you for introducing me to Christopher Marlowe and for sending me to the Globe theatre in London, giving me the opportunity to explore the theatre and the archives firsthand. I'd like to thank my thesis panel, including Micheline White, Paul Nelles and Jennifer Evans, for their kind and thoughtful suggestions which have been a great help to me during this process. As well, I would like to thank Dominique Marshall for all of the support and advice she has provided during my studies here at Carleton. To my parents, thank you for your support during the course of my entire education. Last but not least, thank you to all of my amazing friends here in the history department at Carleton. The meaningful friendships I have made during my two years here have kept me motivated and sane throughout this entire process for which I am forever grateful. 


\section{Table of Contents}

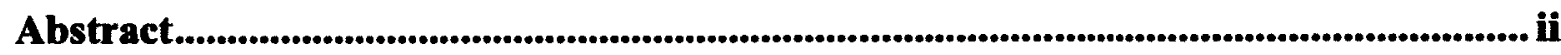

Acknowledgements .............................................................................................................. iii

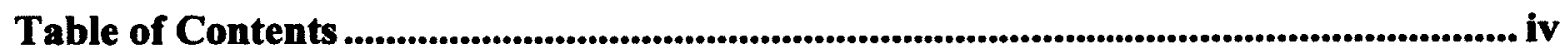

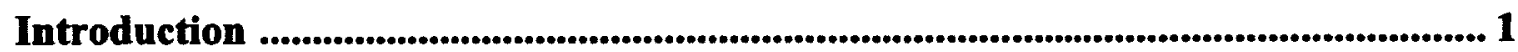

Christopher Marlowe and the Performance of Catholicism ........................................ 1

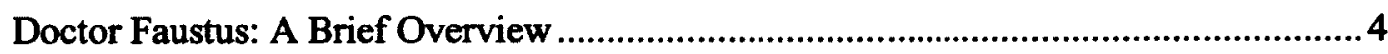

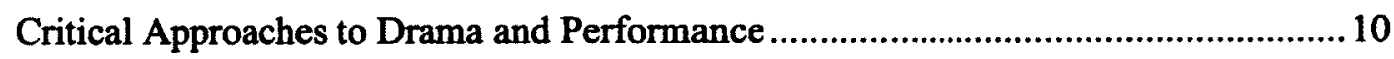

1 Chapter One: Catholicism and Anti-Catholicism in Elizabethan England ........ 16

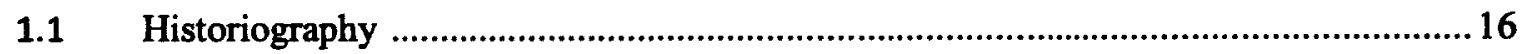

1.2 Catholic Communities and the Language of Anti-Catholicism...............................21

2 Chapter Two: Christopher Marlowe and the Elizabethan Stage.......................... 39

2.1 Christopher Marlowe: Critical Perspectives ........................................................... 39

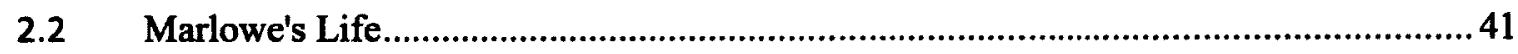

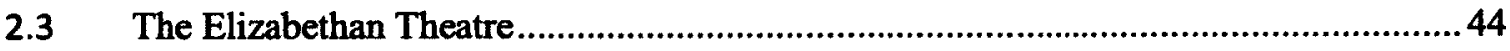

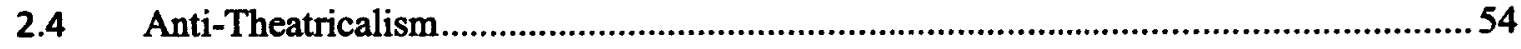

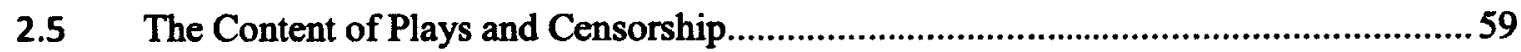

3 Chapter Three: Performing Anti-Clericalism in Doctor Faustus........................ 62

3.1 The B-text of Doctor Faustus in Performance ........................................................... 72

3.2 Anti-Clericalism and Protestant Nationalism in The Jew of Malta and The Massacre at

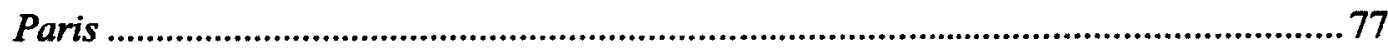

4 Chapter Four: Performing Religion in Doctor Faustus.......................................... 87

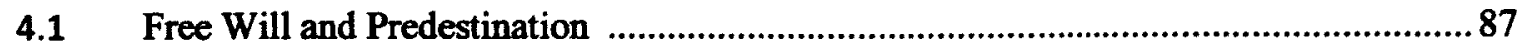


4.2 Theatre, Religion and Magic: Performativity in Doctor Faustus..................................96

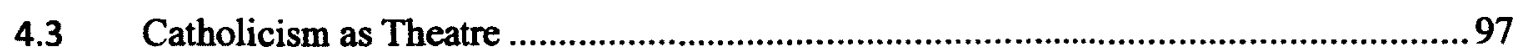

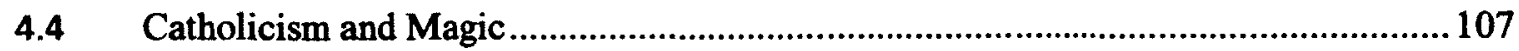

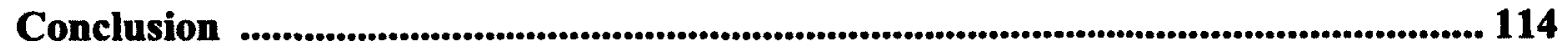

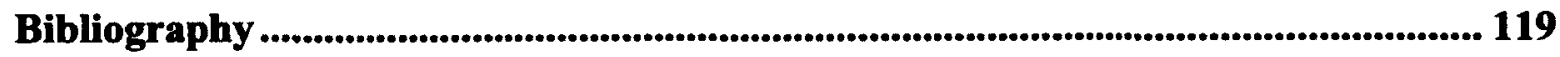




\section{INTRODUCTION}

\section{Christopher Marlowe and the Performance of Catholicism}

In Elizabethan England, the commercial theatre developed into a significant economic and cultural institution. The growing popularity of playgoing during this time coincided with a period of intense religious and political discourse about English Catholics. The Elizabethan religious settlement officially made England a Protestant nation after the brief Catholic reign of Mary I. As a result, the late sixteenth century was characterized by heated debates about the place of religious non-conformists in English society, particularly the Queen's Catholic subjects. The legal and cultural marginalization of Catholics became a topic which appeared onstage in many plays of this period. Christopher Marlowe's tragedy Doctor Faustus deals with questions of religious theology and ceremony. Amidst the growing climate of religious controversy, several key scenes in Marlowe's play would have been interpreted by Elizabethan audiences as specifically anti-Catholic. A study of Marlowe's text reveals that much of the play's anti-Catholicism shares similar language and imagery with other Elizabethan anti-Catholic works. An examination of a modern performance of Doctor Faustus at the Globe theatre in London illustrates that the religious tensions present in the text are complicated through performance. Specifically, it reveals that much of the anti-Catholicism of the play can either be exaggerated or diminished depending on the performative techniques used by actors onstage and by dramaturgical decisions.

Christopher Marlowe has been recognized as one of the most prominent playwrights of the late sixteenth century. Known for introducing blank-verse into Elizabethan poetry, 
Marlowe composed several popular plays before his death in 1592. Doctor Faustus remains Marlowe's most discussed tragedy and has been the subject of considerable scholarship as well as many theatrical revivals. ${ }^{1}$ Marlowe began his literary career when playhouses were first established outside London as fixed performative spaces. Though pageantry and ceremony had long been a part of the cultural world of early modern England, there was never before a permanent stage on which traditional social roles could be inverted and sacred practices demystified in front of a large, popular audience. ${ }^{2}$ The introduction of the playhouse created an arena in which politics, religion and culture could be critically discussed. Alexandra F. Johnston recognizes that "Christian theology, biblical history and moral rectitude were taught through drama; rulers were advised through drama and important issues of state...were discussed obliquely through drama." ${ }^{3}$ As a result, theatres did not only provide entertainment, but became important sites for social and political discourse during this time.

The religious tensions of this period remained an important topic for representation on-stage. In spite of the growing influence of Protestantism, questions about further reform as well as religious toleration for non-conformists remained in Elizabethan England. Anti-Catholicism at home and a growing hatred for Catholic powers abroad became a part of the religious and political discourse of this period creating an environment in which Marlowe's negative representations of Catholics may have resonated with certain audience members.

\footnotetext{
${ }^{1}$ Sara Munson Deats, ed., Doctor Faustus: A Critical Gude (New York: Continuum, 2010).

2 Steven Mullaney, The Place of the Stage: Licence, Play and Power in Renaissance England (Chicago: University of Chicago Press, 1998).

${ }^{3}$ Alexandra F. Johnson, "Tudor Drama, Theatre and Dociety," in A Companion to Tudor Britain, eds. Robert Tittler and Norman Jones (Malden: Blackwell Publishing, 2004), 430.
} 
This thesis begins with an examination of Elizabethan Catholicism, providing an overview of the challenges these communities faced in redefining their religious practices within the context of an increasingly hostile government. There were ongoing religious tensions in this period as national and communal spiritual identities were shifting and constantly subject to re-examination. The place of Catholics within this society was precarious. In addition to facing legal persecution and social hostility, they were increasingly represented as devious and dangerous individuals who posed a threat to the Protestant state. ${ }^{4}$ In order to situate Marlowe's portrayal of Catholics in Doctor Faustus, I briefly examine other forms of representation such as polemical tracts, statutes and proclamations, before turning to examine both texts of Marlowe's Doctor Faustus to see how Catholics are represented within his play. This is followed by an analysis of the 'A' and 'B' textual versions of the play to look for the presence of certain symbols, images, vocabulary and other rhetorical devices which portray Elizabethan Catholics negatively. I contextualize Marlowe's representations within other characterizations of Catholics during this time in order to understand the culture of religious ambiguity that existed within Elizabethan England. The negative discourse about Catholics in this period furthered the suspicion and mistrust that surrounded this religious community. It was within this cultural context that Doctor Faustus reinforced these negative images of Catholic life and worship.

In addition to examining the $\mathrm{A}$ and $\mathrm{B}$ texts of Doctor Faustus, I analyze performances of the play which I witnessed at the Globe Theatre in London in August of 2011. I am concerned with how specific actions, gestures and props used by the actors

\footnotetext{
${ }^{4}$ Peter Lake and Michael Questier, Anti-Christ's Lewd Hat: Protestants, Papists and Players in Post-Reformation England (Yale: Yale University Press, 2002).
} 
either aggravate or diminish the religious tensions that are present within the text.

Recognizing the fluidity and instability of early modern texts and performance, my thesis is concerned with the variety of performance possibilities offered by plays such as Doctor Faustus. Therefore, I use the Globe production as only one example of how such a text can be staged.

\section{Doctor Faustus: A Brief Overview}

Scholars estimate that Doctor Faustus was written in 1588 or 1589 shortly after Marlowe had finished his education at Cambridge. ${ }^{5}$ The first documented performance of the play was on September 30,1594 by the Lord Admiral's Men at the Rose Theatre. This was followed by several other performances that very year, as well as eight more between 1595 and $1597 .{ }^{6}$ Edward Alleyn, the famous Elizabethan actor, played the title role in its earliest productions. Between 1596 and 1603, the play continued to be performed by the Earl of Nottingham's acting company. Doctor Faustus remained popular in the early seventeenth century until the closing of the theatres in 1642 after which it seems to have been forgotten until its revival in the mid eighteenth century. ${ }^{7}$ The play was likely popular due to its intense visuality and spectacle, as well as its dramatic themes which dealt with sin, evil and the consequences of personal ambition. In 1633, William Prynne wrote that during an Elizabethan performance of the play, a real devil

\footnotetext{
${ }^{5}$ Bruce E. Brandt, "The Critical Backstory," in Doctor Faustus: A Critical Guide, ed. Sara Munson Deats (London: Continuum, 2010), 21-23. Others argue that it was written 1592-3, which is based on the fact that an English translation of The Damnable Life, the main source for Marlowe's play, was not published until 1592. The argument for the earlier date is based on allusions made to Faustus in the anonymous play, The Taming of a Shrew and Robert Greene's Friar Bacon \& Friar Bungay.

${ }^{6}$ David Bevington, "The Performance History," in Doctor Faustus: A Critical Guide, ed. Sara Munson Deats (London: Continuum, 2010), 43. Bevington provides a detailed overview of many twentieth and twenty-first century productions.

${ }^{7}$ Ibid., 43-47. The play reappeared on London stages for the first time in 1885.
} 
appeared on-stage alongside the actors which terrified audience members. ${ }^{8}$ The presence of demons and dragons onstage is an example of the type of visual experience which early modern audiences may have found appealing. ${ }^{9}$ Much of the popularity of Doctor Faustus may have been due to the theatrical experience it was able to provide for viewers. To the present day, it remains Marlowe's most performed and most critically debated play. ${ }^{10}$

Though popular in performance, Doctor Faustus was not published in print form until eleven years after Marlowe's death. Two known versions of the text exist; the a-text which was published in 1604 by Valentine Simmes and the b-text published in 1616 by John Wright. The b-text omits thirty-six lines from the a-text text, and then introduces new speeches totalling 676 lines. There are also two extra characters within the b-text, as well as several minor verbal changes from the a-text. Significant dramaturgical, structural and ideological differences also exist between the two texts. In 1602, Phillip Henslowe paid playwrights Samuel Rowley and William Birdie four pounds to make additions to the play. ${ }^{11}$ However, it is unknown what these specific additions were, and how many of them actually made it into either version of the printed text. ${ }^{12}$ As a result, critics have been left with two different versions of the play with no hint as to which is closer to what Marlowe originally wrote. Marlovian scholarship of the twentieth century has tried to establish which of these two versions of Doctor Faustus is more authentic. ${ }^{13}$ In judging

\footnotetext{
${ }^{8}$ Ibid., 41.

${ }^{9}$ Bevington, "The Performance History," 42.

${ }^{10}$ See "Introduction," in Sara Munson Deats, Doctor Faustus: A Critical Guide.

"Laurie E. Maguire, "Marlovian Texts and Authorship," in The Cambridge Companion to Christopher Marlowe, ed. Patrick Cheney (New York: Cambridge University Press, 2004), 48.

${ }^{12}$ Andrew Duxfield, "Modern Problems of Editing: The Two Texts of Marlowe's Doctor Faustus," Literature Compass 2 (2005), 3.

${ }^{13}$ Early scholarship assumed that the 1604 version was closer to what Marlowe had intended. In 1950, W.W. Greg argued for the superiority of the B-text, claiming that it represented the original version
} 
which text is more authoritative, scholars have looked for consistency in themes, language and structure to identify which scenes were likely added by contributors. For example, many seem to agree that the comic scenes of the play were probably not written by Marlowe alone as they do not fit in with the dramatic tone of the rest of the play. However, there is little overall consensus on how much of the play as it currently exists was written by the dramatist himself.

In recent years, some scholars have begun to argue that neither version of Doctor Faustus is truly authentic. Recognizing the inherent instability of early modern texts, David Scott Kastan finds that "plays always register multiple intentions...as actors, annotators, revisers, collaborators, scribes, compositors, printers, and proofreaders, in addition to the playwright, all have a hand in shaping the play text." ${ }^{14}$ In many ways, an 'original' text never existed at all, as what Marlowe initially wrote was altered with every performance and publication. Leah Marcus and Michael Warren advocate studying both texts as separate texts altogether. ${ }^{15}$ This is significant because each text provides different thematic readings of the play and can be used to support different conclusions about the content of the play itself. Therefore, it is important to distinguish between the two and recognize that each version has its own socio-cultural context. Many modern printed editions of Doctor Faustus now present both versions of the play with an introduction discussing the similarities and differences between the two. ${ }^{16}$

which 'progressively adapted to the needs of a declining company and the palate of an uncultivated audience.' In 1975, arguments for the A-text re-emerged led by Constance Brown Kuriyama. Modern editors tend to produce which ever version of the text they personally feel to be more authoritative. An overview of this debate can be found in Duxfield, "Modern Problems of Editing."

${ }^{14}$ David Scott Kastan, Shakespeare after Theory (New York: Routledge, 1999), 63.

${ }^{15}$ Duxfield, "Modern Problems of Editing," 11.

${ }^{16}$ Bevington and Ramussen's version is often cited as the most important. Christopher Marlowe, Doctor Faustus, eds. David Bevington and Eric Ramussen (Manchester: Manchester University Press, 
It is also important to recognize the performative possibilities of these two versions of the play because the majority of the Elizabethans who encountered Doctor Faustus did so through the playhouse and not through reading the text. It is unlikely that the scripts which modern scholars have access to resemble what was performed on stage within the sixteenth century. The groups of players who performed Doctor Faustus had considerable autonomy in their interpretation of the play, which provided numerous possibilities for how the production was to be organized and presented to audiences. Therefore, different performances of the same text could be markedly different from one another. As a result, it is problematic to argue that either the a-text or b-text of Doctor Faustus is closer to a Marlovian original because the two versions of the play, both as textual artefacts and especially as performative pieces, have an inherent fluidity that has existed from their first composition.

In modern printed editions of Doctor Faustus, the play has been divided into five acts, with the a-text containing fourteen scenes, and the b-text twenty-one. Both versions are framed with a prologue and an epilogue establishing the major themes of the play which deal with the consequences of a young scholar's ambitions. In this, Doctor Faustus borrows elements from the traditional morality play of the early modern period. Popular during the renaissance, morality plays commonly used allegory and symbolism to encode moral lessons for audiences. ${ }^{17}$ Within Doctor Faustus, abstract concepts such as temptation and sin as well as repentance and damnation are represented through characters such as the good and evil angels, the Old Man and the seven deadly sins. The

1993). W.W. Greg provides both texts side by side. Christopher Marlowe, Doctor Faustus, ed. W.W. Greg (Oxford: Clarendon Press, 1950).

${ }^{17}$ Douglas Cole, Christopher Marlowe and the Renaissance of Tragedy (Westport, Conn.: Greenwood Press, 1995), 30-31. 
battle between good and evil as well as Faustus' place within this conflict remains a central theme within the play. Faustus' ambition, pride and eventual damnation allow him to wrestle internally with these concepts. However, the moral lesson that the audience is ultimately left with is a mixed one and has been the source of much critical debate.

Within the traditional morality play, the central character represents 'everyman,' and his or her journey can be generalized to reflect some greater part of the human condition. Much of the scholarship surrounding Faustus' character has attempted to establish whether Faustus is someone that audiences would have been able to identify with, or if he is a unique personality whose spectacular journey is far removed from sixteenth century life. The character of Faustus himself has been interpreted in several different ways. One line of scholarship sees him as a tragic humanist hero whose quest for knowledge and personal ambition leads to his downfall. ${ }^{18}$ Others see him as a foolish individual who wastes his attained power on frivolous pursuits and childish activities. Those studying the religious undertones of the play attempt to discern to which extent Faustus' actions are self-guided, and to which extent he is victim to forces of good and evil beyond his control. It is difficult to assess how much sixteenth century audiences would have sympathized and identified with Faustus' character, or how much they would have judged and blamed him for his own damnation. Nevertheless, he remains a complex figure whose exploration of sin, damnation, salvation and penitence may have spoken to post-Reformation audience members who were themselves grappling with these concepts.

\footnotetext{
${ }^{18}$ Harry Levin, The Overreacher: A Study of Christopher Marlowe (Cambridge: Harvard University Press, 1952).
} 
Marlowe based Doctor Faustus on The Damnable Life, a collection of stories compiled by Johann Spies. Also known as the Faustbook, this collection of stories deals with the life and adventures of the renowned fifteenth century German magician Georgius of Helmstadt who would later be known as Johannes Faustus. ${ }^{19}$ Legends about powerful sorcerers had a long tradition in the ancient, medieval and early modern world. Tales of the miraculous works of Simon Magus, St. Cyprian, Virgil and John Dee may have also influenced the character of Faustus. ${ }^{20}$ The essential storyline of Faustbook is used as the basis for Marlowe's play. They both discuss Faustus' twenty-four year pact with the devil and his experiences leading to his damnation at the end of the story.

Much like the Faustbook, Doctor Faustus can be divided thematically into three parts. ${ }^{21}$ The first part of the play deals with Faustus' frustration with academia, his exploration of magic, and his pact with Mephistopheles for supernatural power. The second part of the play deals with his many adventures and his quest for knowledge and fame while part three deals with Faustus' damnation and the consequences of his bargain with the devil. Marlowe however, explores a psychological dimension of Faustus that the Faustbook does not. Within the collection of stories, the motivations for Faustus' behaviour include his curiosity for knowledge and desire for material pleasures. Within Marlowe's play, Faustus' motivations are more complex and his thirst for endless knowledge reveals deeper aspirations for power, wealth and fame. ${ }^{22}$ Other differences between the Faustbook and the play include the length of time it takes Faustus to

\footnotetext{
${ }^{19}$ Bevington and Ramussen, Doctor Faustus, 4.

${ }^{20}$ Ibid., 8-9

${ }^{21}$ P.F. Gent, trans., The historie of the damnable life, and deserued death of Doctor lohn Faustus. London: Printed by Thomas Orwin, 1592. From Early English Books Online STC10711/925:02. http://eebo.chadwyck.com.proxy.library.carleton.ca/search/full_rec?SOURCE=config.cfg\&action=byid\&I $\mathrm{D}=99849441$ \&SUBSET $=$. (Accessed December 2, 2011).

${ }^{22}$ Deats, "Introduction," in Doctor Faustus: A Critical Guide, 9.
} 
negotiate his pact with Mephistopheles which is significantly shorter in the play than within the book. As well, the Faustbook contains more detailed and spectacular episodes of Faustus' travels and adventures than any performance of the play would logistically be able to reproduce. ${ }^{23}$ Overall, Marlowe is able to produce a work that borrows elements from both the traditional morality play of the early modern period and a well-known legend about a German sorcerer. His contribution to this story is that he explores the psychological torments of his central character in a way that produces mixed feelings about the consequences of $\sin$ and the nature of redemption and damnation.

Through his exploration of these questions, Marlowe makes many direct and indirect references to Christian theology and institutions within Doctor Faustus. Several instances within the play specifically deal with Catholicism which is represented as a religion that is both spiritually absurd and powerless, and yet politically threatening and dangerous. This interpretation of the text would have resonated with sixteenth century Protestant attitudes towards English Catholicism. Within the play, Marlowe makes several anti-clerical references that present the clergy as foolish and powerless individuals which is a theme which he repeats within his 1592 play, The Jew of Malta. Marlowe's representation of the Pope in Doctor Faustus alludes to issues of Protestant nationalism and monarchical authority, especially in the b-text version of the play. In his 1593 work, the Massacre at Paris, Marlowe expands considerably on this theme to produce a work which may reflect contemporary fears of Catholic rebellion occurring in England. These representations are significant because they reveal tropes, language and symbols that were available to culturally 'other' Catholics within sixteenth century English society.

\footnotetext{
${ }^{23}$ Bevington and Ramussen, Doctor Faustus, 5.
} 


\section{Critical Approaches to Drama and Performance}

There are numerous critical approaches to the study of Renaissance drama. ${ }^{24}$ Until the 1980s, many of these approaches examined plays solely as literary artifacts. However, due to the rise of performance studies within this period, criticism of drama now recognizes that these plays were performative pieces, and that the very cultural acts of playmaking need to be included in any meaningful discussion about Elizabethan literature. Examining the history of literary scholarship, William B. Worthen recognizes that "text and performance have long seemed to compete for legitimacy as means of representing drama." 25 Only in the last few decades have scholars begun to examine the complex and dynamic relationship between texts and performance. As a result, many scholars have turned to performance studies in order to understand how these works were staged and presented to sixteenth century audiences.

Performance theory seeks to analyze the range of meanings that can be created within theatrical spaces. Elements of mis-en-scene and stage production such as costumes, hand properties, lighting, music, as well as the use of space and gesture help to create theatrical experiences or 'energies' that encode meanings for theatregoers. ${ }^{26}$ The relationship between actors, audiences, texts and the medium of the stage also contributes

\footnotetext{
${ }^{24}$ All of these approaches are clearly and thoroughly summarized within Russ McDonald, ed., Shakespeare: An anthology of criticism and theory, 1945-2000 (Malden: Blackwell, 2004).

${ }_{25}$ William B. Worthen, "Deeper meanings and theatrical technique: The rhetoric of performance criticism," in Shakespeare: An anthology of criticism and theory, 1945-2000, ed. Russ McDonald (Malden: Blackwell, 2004), 763.

${ }^{26}$ Stephen Greenblatt talks about theatrical and social energies in relation to the networks of meaning that are developed onstage. Greenblatt argues that "social energy is manifested in the capacity of certain verbal, aural and visual traces to produce, shape and organize collective physical and mental experiences." All artistic forms contain social energy which is negotiated and subject to shifts. Stephen Greenblatt, Shakespearean Negotiations: The Circulation of Social Energy in Renaissance England (Oxford: Clarendon Press, 1990).
} 
to this notion of 'theatrical energy. ${ }^{, 27}$ Performance studies also examine how plays are advertised, as well as the social and cultural behaviors involved in playgoing. Scholars examine how individuals adopt the role of audience-member and the ways in which they participate in the theatrical energy of the performance.

Practitioners of performance studies understand performance to be equally as important as text in understanding the dramatic quality of any given play. ${ }^{28}$ The desire to understand the relationship between text and theatrical representation can be seen within critical approaches such as 'New Historicism' and 'Cultural Materialism' which examine literary texts and their modes of performance as interrelated social acts. ${ }^{29}$ These scholarly approaches examine literature as cultural artifacts which are intricately tied to their historical context. New Historicists argues that texts, as well as the very process of studying literature, cannot be dehistoricised. Literature does not transcend the time and place in which it was initiated, and many of the meanings it produces are directly related to the conditions under which it was first created and performed. There is an attempt by these scholars to assess the relationship between literary and non-literary texts, as well as their relationship to their author and the environment in which they were first produced and circulated. ${ }^{30}$

In New Historicist studies, scholars often look for opposing ideological conflicts within literature, as these conflicts may reflect the wider social tensions that existed

\footnotetext{
${ }^{27}$ Freddie Rokem, Performing History: Theatrical Representations of the Past in Contemporary Theatre (lowa: University of Iowa Press, 2000), draws on Greenblatt's concept of social energies in his discussion of theatrical energies.

${ }^{28}$ Worthen, "Deeper meanings," 767-777.

${ }^{29}$ Prominent New Historicists and cultural materialists include Arthur Marotti, Steven Mullaney, Alan Sinfield, Leah Marcus, Louis Montrose and Jonathan Dollimore.

${ }^{30}$ Harold Aram Veeser, The New Historicism (New York: Routledge, 1989), 2.
} 
during the creation of these texts. ${ }^{31}$ New historicists reject that any historical age has one dominant social or political viewpoint. Instead, they look for opposing voices within a text, focusing on representations and depictions of various cultural 'others' through certain phrases and images. ${ }^{32}$ This line of criticism has helped to reveal the ways in which Elizabethan drama encoded social and political tensions within text and performance. In the plays of Christopher Marlowe, much of this tension surrounds English and European Catholics who are 'othered' in both text and performance.

This concern for opposing voices within literature reveals a concern about the subversive potential of any text many New Historicists share with Cultural Materialists. Because these texts encode contemporary social and political conflicts, they contain characters and themes which may challenge and subvert traditional customs and hierarchies. Jonathon Dollimore argues that Shakespeare in particular commonly undermined the prevailing ideologies of the Elizabethan period. ${ }^{33}$ Stephen Greenblatt argues that though these texts produce subversive ideas, they ultimately do so only to reinforce the ruling classes' monopoly on power. In other words, these plays both produce and contain subversion. Plays create or give voice to 'the other' but only in such a way as to reinforce traditional power structures. Greenblatt states that the dominant power produces and contains subversiveness so that it can "study, discipline, correct and transform" the alien voices and radical ideas produced in the text. ${ }^{34}$ As a result, these

${ }^{31}$ Jan R. Veenstra, "The New Historicism of Stephen Greenblatt: On Poetics of Culture and the Interpretation of Shakespeare," History and Theory 34 (1995): 184.

${ }^{32}$ Emma Smith, The Cambridge Introduction to Shakespeare (New York: Cambridge University Press, 2007), 19.

${ }^{33}$ Thomas McAlindon, Shakespeare Minus 'Theory' (Aldershot: Ashgate, 2004), 89.

${ }^{34}$ Quoted from McAlindon who sharply disagrees with Greenblatt, finding "how Shakespeare who is consciously devoted to demystifying a particular power structure could write plays designed to reinforce it or how any audience presented with so fiercely a negative view of monarchical authority could be persuaded to glory in it is an assault on common sense" McAlindon, Shakespeare Minus 'Theory, ' 32. 
texts do not mirror their histories but participate directly in them. Elizabethan cultural constructions of individuals, the state and 'the other' are bound up in their representations within these texts.

The impact of New Historicism has been an increased focus on understanding the modes of cultural production that led to the creation and performance of literary texts. It has led critics to examine the dynamic relationship between text and context. Similarly, I seek to examine this play as both textual artifact and as a performative piece. There are instances within Marlowe's text that produce anti-Catholic readings of the play. I attempt to understand how these issues can be clarified or complicated through performance. Many of these scholars recognize that each performance produces new meanings which must be historicized. As William B. Worthen writes, in order "to understand the drama, we need to understand all the ways that we make it perform." 35 Therefore, this study of Christopher Marlowe's Doctor Faustus includes an analysis of the author's life and environment; the nature of Elizabethan theatre and the culture of playgoing; and a historicized textual examination of the plays themselves in order to understand all the ways in which contemporaries may have understood his work to be meaningful.

This thesis is not, however, a straightforward New Historicist project; I only engage with this theory to the extent that it emphasizes the need to contextualize Doctor Faustus as a historical text and as a cultural artifact. New Historicism provides the understanding that Marlowe's work did not mirror the religious tension of this period but participated directly in the conflicts of this period through the physical and spiritual challenges that Faustus encounters during the course of his adventures. Similarly, I am not concerned with undertaking a complete performance analysis of the Globe production

${ }^{35}$ Worthen, "Deeper Meanings," 772. 
of Doctor Faustus. Instead, I use knowledge of performance theory to broaden my understanding of theatrical techniques as well as develop a vocabulary about performance and movement onstage. I examine the Globe performances as examples of the numerous staging possibilities for Doctor Faustus in order to comprehend how potentially antiCatholic representations were mediated and created in theatrical spaces. Specifically, I am concerned with how the anti-Catholic instances within Doctor Faustus are manipulated on-stage and how the context of Elizabethan England provided many interpretive possibilities for these representations. Doctor Faustus was composed and performed when both the cultural popularity of theatregoing, as well as the religious landscape of Elizabethan England, were undergoing significant shifts. In this context, the representation and performance of Catholics and Catholicism in Marlowe's Doctor Faustus could contribute to the already negative cultural perception of Catholics in many nuanced and meaningful ways. 


\section{CHAPTER ONE: Catholicism and Anti-Catholicism in Elizabethan England}

\subsection{Historiography}

The historiography of Elizabethan Catholicism begins with studies of the Protestant Reformation in England. Following the 'Whig' tradition of English histories, most narratives of the Reformation until the mid-twentieth century emphasized the triumph and growth of Protestantism over the declining and increasingly unpopular traditional practices of late medieval Catholicism. This tradition began with John Foxe's 1563 Acts and Monuments (better known as the Book of Martyrs) and might be said to culminate with A.G. Dickens' 1964 work The English Reformation. Within these histories, the Reformation is presented as an event which was built on a strong English tradition of anti-clericalism. ${ }^{36}$ After the Elizabethan religious settlement of 1559, Catholicism was assumed to have faded into a minority religion in the growing shadow of Protestantism. Discussion of Catholicism after the Reformation tended to focus on either persecution and martyrdom, or the eventual assimilation of Catholicism into the Established Church. ${ }^{37}$ These histories presented Catholics as either "preached at or persecuted," and made little attempt to understand the lives of those Catholics who neither converted to Protestantism nor became martyrs for their religion. ${ }^{38}$

During the 1970s and 1980s, historians such as Eamon Duffy, J. J. Scarisbrick and Christopher Haigh began to challenge this tendency to view Catholicism as victim to

\footnotetext{
${ }^{36}$ An example of this tradition of anti-clericalism would be the followers of John Wycliffe, as presented within A.G. Dickens, The English Reformation (London: Batsford, 1964).

${ }^{37}$ Richard Verstegan probably serves as the best contemporary example, creating what Christopher Haigh terms "a model of resolution and self-sacrifice that sustained Catholic lives which was repeated by Richard Challanoer in 1741 and John Morris in the 1870s. Christopher Haigh, "Catholicism in Early Modern England: Bossy and Beyond," The Historical Journal 45 (2002), 482.

${ }^{38}$ Ibid., 481-482.
} 
the Protestant Reformation. ${ }^{39}$ These revisionists argued that late medieval Catholicism was a popular, vibrant religion and that the Reformation was an event imposed on the English people by Henry VIII and his ministers. ${ }^{40}$ According to revisionists, Catholicism remained the religion of the majority and Protestantism was only gradually accepted over the course of several generations. The ensuing debate among Reformation historians became one which attempted to discern to what extent the Protestantization of England was a popular movement "from below," or an event which was imposed by the crown "from above". Connected to this debate was the issue of whether the Reformation happened rapidly or if it was a process which unfolded over several generations. ${ }^{41}$ The most recent scholarship seems to suggest that the Reformation was indeed a movement initiated by the crown, and that it did take several generations for England to become a mostly Protestant nation. This was a process, some have argued, that continued well into the reign of Elizabeth $\mathrm{I}^{42}$

Revisionist historians of the English Reformation brought attention to the continued importance of Catholicism in many early modern English communities. They challenged the notion that Catholicism faded after the Reformation, and examined how it transformed and adapted itself as Protestantism gradually took hold in the later sixteenth century. In 1970, John Bossy furthered the development of the historiography of early modern Catholicism with his landmark work, The English Catholic Community 1570-

\footnotetext{
${ }^{39}$ A summary of Catholic scholarship on the English Reformation can be found in John Vidmar, English Catholic Historians and the English Reformation, 1585-1954 (Brighton: Sussex Academy Press, 2004).

${ }^{40}$ J.J. Scarisbrick. The Reformation and the English People (New York: Blackwell, 1984); Christopher Haigh, Reformation and Resistance in Tudor Lancashire (Cambridge: Cambridge University Press, 1975); Christopher Haigh, English Reformations (New York: Oxford University Press, 1993), 12-21.

${ }^{41}$ For an overview of this debate, please see Andrew Pettegree, "A.G Dickens and his Critics: A New Narrative of the English Reformation," Historical Research 77 (2004), 39-58.

${ }^{42}$ See 'Introduction,' to Norman Jones, The English Reformation: Religion and Cultural Adaptation (Oxford: Blackwell, 2002).
} 
1850. Bossy suggested that after the Elizabethan religious settlement a new Catholic community emerged which was markedly different from its late medieval predecessor. He argued that this new community was largely a construction of the Jesuits and missionaries who came to England during the Marian counter-Reformation and after. Furthermore, he writes that Catholicism gradually became a religion of the gentry who were able to financially support missionary efforts and hide priests from Protestant authorities. ${ }^{43}$ Bossy's view did not go unchallenged; for example, Christopher Haigh argued that although the Catholic community may have indeed undergone changes over the course of the Reformation, it retained strong ties to its late medieval past. Known as the 'continuity thesis,' Haigh maintained that the Catholic community in the postReformation environment was not significantly different from that which came before. ${ }^{44}$ The debate which followed attempted to discover if the history of Catholicism after the Reformation was about the transformation of an old community, or the rise of a new minority sect. ${ }^{45}$

Over the last two decades, historians have broken away from this debate between Bossy and Haigh and have focused instead on the dynamics of Catholic beliefs and practices from the mid sixteenth century onwards. These post-revisionist historians of English Catholicism include Michael Questier, Lucy Wooding, Alexandra Walsham and Ethan Shagan who have attempted to understand how Catholic communities adapted their religious practise during the Reformation as they transitioned into a period where

\footnotetext{
${ }^{43}$ John Bossy, The English Catholic Community 1570-1850 (London: Darton, Longman \& Todd, 1975).

${ }^{44}$ Christopher Haigh, "Catholicism in Early Modern England: Bossy and Beyond," The Historical Journal 45 (2002), 481-494. "The Fall of a Church or the Rise of a Sect: Post-Reformation English Catholicism," The Historical Journal 21 (1978), 181-186.

${ }^{45}$ Haigh, "The Fall of a Church or the Rise of a Sect," 181-186.
} 
Protestantism was gradually taking hold. ${ }^{46}$ They have attempted to place Catholicism in the wider context of English culture in order to understand how Catholic identities and communities were formed and sustained within the post-Reformation period. Historians such as Alexandra Walsham have brought attention to the problem of religious definitions within this period and the need to understand Catholicism outside such concepts as "church papistry" or "recusancy." 47 Michael Questier argues for the need of a "more developed, politically sensitive model of Catholicism in this period..." which can be achieved if historians study "what contemporaries, particularly Catholics, said about Catholicism, and in what political contexts, in order to see how post-Reformation Catholicism was defined."48

In order to discover how Catholicism was understood by contemporaries, historians such as Peter Lake and Norman Jones have studied how it developed in the context of other religious cultures of this period. Lake in particular has studied how forms of Catholicism and Protestantism interacted, and how these groups may have perceived themselves in relation to one another. ${ }^{49}$ Instead of examining Catholic communities in isolation, Catholicism has been placed into the wider political, cultural and social world of sixteenth century England. By recontextualizing Catholicism in this way, historians have begun to understand how the process of religious change took place in the

\footnotetext{
${ }^{46}$ The following is a sample of these post-revisionist works, Ethan Shagan, ed. Catholics and the 'Protestant Nation' (Manchester: Manchester University Press, 2005); Michael Questier, Catholicism and Community in Early Modern England (Cambridge: Cambridge University Press, 2006); Alexandra Walsham, Church Papists (Woodbridge: The Boydell Press, 1999).

${ }^{47}$ 'Church Papistry' refers to those individuals who outwardly conformed to the Protestant church, but continued to secretly practice Catholicism. 'Recusant' is a general term which refers to anyone who refuses to attend Protestant services. Walsham demonstrates that these terms fail to include those who occasionally conformed to the established church, as well as the fact that one Catholic could exhibit all of these types of behaviours at different points in his or her life. Walsham, Church Papists, 1999. (2000), 32

${ }^{48}$ M.C Questier, "What Happened to English Catholicism after the Reformation?," History 85

49 Jones, The English Reformation, 2002; Lake and Questier, Anti-Christ's Lewd Hat.
} 
Elizabethan period, and which factors shaped the construction and representation of religious identities. The very concept of religious boundaries has been complicated by these works which have shown how permeable confessional divides could often be in this period. $^{50}$

Catholic historiography has also been impacted by the emergence of numerous county studies. J.C.H Aveling's study of Yorkshire, S.J Watt's investigation of Northumberland and A.L Rowse's work on Cornwall have brought attention to how Catholicism was practiced on a parish level. ${ }^{51}$ Patricia Crawford and Roland Connelly have studied how women in particular were responsible for sustaining Catholic practices within these local communities. In his 2006 study, Catholicism and Community in Early Modern England, Michael Questier has looked at one prominent family specifically, the Brownes of Cowdray, and how religion, politics and family dynamics operated within their social network. ${ }^{52}$ What all these studies reveal is that there was no singular Catholic experience within the Elizabethan period. Nuanced variations could exist when it came to religious belief and practices amongst different families and communities. Furthermore, the experience of Catholics could vary considerably depending on how the local and national political climate changed within this period. ${ }^{53}$

${ }^{50}$ This is not to suggest that 'Protestantism' and 'Catholicism' did not exist as recognizably different phenomenon to contemporaries, only that this was a dynamic process that involved degrees cultural exchange and was constantly changing over time.

${ }^{51}$ J.C Aveling, Catholic Recusancy in the City of York 1558-1791 (London: Catholic Record Society, 1970); S.J. Watt, From Border to Middle Shire: Northumberland 1586-1625 (Leicester: Leicester University Press, 1975); A.L. Rowse, Tudor Cornwall: Portrait of a Society (London: Macmillan, 1969).

${ }_{52}$ Patricia Crawford, Women and Religion in England, 1500-1720 (London: Routledge, 1993); Roland Connelly, The Women of Catholic Resistance in England, 1540-1680 (Edinburgh: Pentland Press, 1997); Michael Questier, Catholicism and Community in Early Modern England (Cambridge: Cambridge University Press, 2006).

${ }_{3}^{3}$ Lisa McClain, Lest We Be Damned: Practical Innovation and Lived Experience amongst Catholics in Protestant England (New York: Routledge, 2004), 3-7. 
The historiography of post-Reformation English Catholicism has therefore changed considerably over the past several decades. Abandoning the notion that Catholicism disappeared after the Reformation events, historians have increasingly focused on how this religion was transformed during the Elizabethan period. Their research has brought attention to how Catholics adapted their religious practices, interpreted their changing social world and interacted with other religious communities at this time. As a result, historians have provided significant insight into how Catholics lived after the Elizabethan religious settlement of 1559.

\subsection{Catholic Communities and the Language of Anti-Catholicism}

Assuming the title 'Supreme Governor' of the English Church, Elizabeth returned England's official religion to Protestantism following the brief counter-Reformation of Queen Mary's reign. The Protestant Book of Common Prayer was now to be used in church services and all individuals were expected to attend Sunday and holy day services. As well, participants were expected to receive Protestant communion three times a year. Catholic practices including feasts, processions and celebration of saint's days were now prohibited and the traditional seven sacraments were reduced to two. Religious services were simplified and the traditional omaments of Catholic worship such as altarpieces were removed. ${ }^{54}$ Although churches once again became officially Protestant, it is likely that devotional practices resembling Catholicism continued within them, at least for the early part of Elizabeth's reign. ${ }^{55}$ Nevertheless, as Protestantism was gradually

\footnotetext{
${ }^{54}$ Ibid., 3.

${ }^{55}$ Eamon Duffy, The Stripping of the Altars: Traditional Religion in England, 1400-1580 (New Haven: Yale University Press, 1992).
} 
reintroduced into local communities, Catholics faced increasing difficulties in continuing to sustain these practices.

No longer able to convene within churches, one of the challenges Elizabethan Catholics faced during this time was finding new locations in which to worship. Forced to meet secretly in barns, homes and other private locations, Catholics had to redefine how they constructed sacred space, as well as adapt how their rituals were performed. ${ }^{56} \mathrm{~A}$ priest was not always available to administer sacraments or lead prayers and mass which meant that Catholics had to find new ways to organize their traditional services. In order to do so, they had to find new means to receive the spiritual functions of the sacraments without performing the same rituals and using the same material objects that they used in the past. ${ }^{57}$ This often meant reinterpreting devotional practices and adapting them to the changing physical environment in which they were conducted.

One of the ways in which Catholics sustained their practices within this period was through literature and print culture. Challenging the traditional argument that Protestantism was the "religion of the book," historians have begun to recognize the importance of the written word to Catholic communities during this time. ${ }^{58}$ Devotional texts, saint's lives, breviaries, and martyrologies helped Catholics retain a sense of

\footnotetext{
${ }^{56}$ Lisa McClain, "Without Church, Cathedral or Shrine: The Search for Religious Space among Catholics of England, 1559-1625," The Sixteenth Century Journal 33 (2002), 381-399.

${ }^{57}$ Lisa McClain, "Using What's at Hand: English Catholic Reinterpretations of the Rosary," The Journal of Religious History, 27 (2003), 161-176. McClain argues that the rosary developed an increasing importance during this period as an object of devotion. Small and portable, it was easy to carry around and did not require a priest to imbue it with religious importance.

58 Alexandra Walsham, "Domme Preachers: Post-reformation English Catholicism and the culture of print," Past \& Present 68 (2000): http://www.jstor.org.proxy.library.carleton.ca/stable/651306 (accessed September 28, 2010), 72-123; Alison Shell, Catholicism, Controversy and the English Literary Imagination (Cambridge: Cambridge University Press, 1999); A.C Southern, Elizabethan Recusant Prose 1559-1582 (London: Sands, 1950). Similar studies challenging the connection between print and Protestantism on the continent have been done, these include Andrew Pettegree and Matthew Hall, "The Reformation and the Book: A Reconsideration," The Historical Journal 47 (2004), 785-808.
} 
community and uphold traditional beliefs both during and after the Reformation.

Underground networks developed to import these works from the continent while some

Catholic printing presses continued to operate secretly in England to produce works for local communities. ${ }^{59}$ Written works were especially important as an instructional aide when a priest was unavailable to conduct services. Seventeenth century priest William Stanney produced such writings which outlined how Catholics could perform traditional rituals without a religious leader present. Though these texts could not replace the mediating function of priests, they did provide practical alternatives for traditional worship. ${ }^{60}$

The Catholic priesthood of the early years of Elizabeth's reign was made up of men who had served the community under Mary I and who remained in England after her death. These priests relied heavily on local communities for cover from Protestant authorities once Elizabeth's religious settlement came into effect. ${ }^{61}$ Though these priests would travel around England to different communities, they tended to congregate in areas where there existed large numbers of Catholics, such as Cornwall, Lancashire and Yorkshire. Recognizing the need for a larger priesthood to sustain the English Catholic population, Rome began to send Jesuit priests and missionaries to England in the $1570 \mathrm{~s}^{62}$ Within the early decades of the mission, Jesuits remained hopeful that England could still reconvert to Catholicism; therefore, many insisted that Catholics continue to practice traditional services and not conform with Protestantism to any degree whatsoever. In the

${ }^{59}$ Walsham, "Domme Preachers," 72-123.

${ }^{60}$ McClain, Lest We Be Damned, 47.

${ }^{61}$ Ibid., 34.

${ }^{62}$ The successes of these Catholic missions continue to be debated by historians of this period who study the ability of missionaries to establish and maintain a communications network, win converts back to the church, and provide religious services for wealthy and poorer Catholic families alike. McClain, Lest We Be Damned, 35-37. 
1590s, following the execution of Mary Queen of Scots as well as the failure of the Spanish Armada, it became increasingly clear that England was to remain Protestant. ${ }^{63}$ The Jesuits abandoned their hope for a Catholic restoration and instructed priests to be adaptable and flexible in their instruction of the laity. ${ }^{64}$ This often caused friction amongst priests who debated to which degree Catholics should adapt to, and cooperate with, the growing Protestant majority. ${ }^{65}$

The arrival of priests and missionaries from the 1570s onward began to attract the attention of local and national authorities who viewed their presence as a threat to religious uniformity and political stability. It was around this time that Catholics became the subject of heightened legal persecution. English Catholics were first persecuted under treason laws established during the Henrician Reformation. First passed in 1536, these laws made it illegal to deny the Act of Supremacy which recognized the monarch as the head of the English church. ${ }^{66}$ For the English state, allegiance to the Pope became a sign of political subversion. As a result, adherence to Catholicism was not only seen as a form of social deviance but was also reframed in political terms as a treasonous act.

During the early years of Elizabeth's reign, these treason laws were enforced sporadically and punishments remained relatively lenient. However, from the $1560 \mathrm{~s}$ onwards, tension between the Protestant regime and both domestic and international Catholicism increased. As a result, so did the frequency and severity of persecution. Conflict with Mary Queen of Scots, as well as Catholic Ireland, France and Spain led to

\footnotetext{
${ }^{63}$ McClain, Lest We Be Damned, 42-45.

${ }^{64}$ Ibid., 45.

${ }^{65}$ The debate which took place amongst Catholic leaders is best explored in Ginerva Crosignani, Micheal Questier and Thomas M. McCoog, eds., Recusancy and Conformity in Early Modern England: Manuscript and Printed Source in Translation (Toronto: Pontifical Institute of Medieval Studies, 2010).

${ }^{6}$ Brad Gregory, Salvation at Stake: Christian Martyrdom in Early Modern Europe (Cambridge: Harvard University Press, 1999), 187.
} 
English fears about a foreign invasion. This was aggravated by the 1570 Papal Bull Regnans in Excelis which excommunicated Elizabeth from the Church and absolved Catholics from owing allegiance to her government. ${ }^{67} \mathrm{~A}$ Catholic rebellion in the North in 1569 , in addition to the arrival of the Jesuit missionaries in the 1570 s, also contributed to anxieties about Catholic communities in England. As a result, new penal laws were passed in 1571 which made it a treasonable offence to challenge the monarch's legitimacy based on religion, and to convert individuals to the Catholic faith. ${ }^{68}$ In 1581 , due to pressure from Protestant bishops in parliament, more statutes followed which increased fines for recusancy and made it treasonable to help Catholic priests immigrate to England. ${ }^{69}$ In 1585 , the Act against Jesuits and Seminarians was also passed which declared English Catholic priests de facto traitors. ${ }^{70}$

From the 1570s onward, rates of persecution fluctuated and tended to be higher in periods where there was a greater perceived Catholic threat. Between 1570 and 1603, 189 Catholics were martyred. The majority of these martyrs were seminary priests and thirty were Jesuit missionaries, all of whom were executed as political traitors. ${ }^{71}$ The stories of their deaths were eventually recorded, and disseminated both orally, in print and manuscript amongst Catholic worshippers. Martyrdom narratives would become an important cultural symbol amongst Catholic communities as a representation of the

\footnotetext{
2003), 10-15.

${ }^{68}$ McClain, Lest We Be Damned, 21.

${ }^{69}$ Antoinina Bevan Zlater, Reformation Fictions: Polemical Protestant Dialogues in Elizabethan England (New York: Oxford University Press, 2011) 99.

${ }^{70}$ Susannah Brietz Monta, Martyrdom and Literature in Early Modern England (Cambridge: Cambridge University Press, 2005), 22. On the evolution of treason laws, see Chapter One of D. Alan Orr, Treason and the State: Law, Politics and Ideology in the English Civil War (Cambridge: Cambridge University Press, 2002).

${ }_{11}$ Geoffrey F. Nuttal, “The English Martyrs, 1535-1680: A Statistical Review," Journal of Ecclesiastical History 22 (1971), 193-194.
}

${ }^{67}$ Sarah Covington, The Trial of Martyrdom (Notre Dame: University of Notre Dame Press, 
hardships they endured and of the resolve they would need in order to sustain their faith. ${ }^{72}$ The executions themselves functioned as spectacles which reinforced the state's attitudes towards religious dissent and the perceived threat of Catholicism.

During the Elizabethan period, there was a great deal of negative discourse which surrounded English Catholics and the alleged instability they brought to the nation. These negative representations provided the context for the persecution and penal laws of this time. In recent decades, historians have examined these characterizations in order to understand the culture of mistrust and fear that surrounded Catholics, and how this may have impacted how they were represented and treated. These historians have turned to literature, art and theatre to examine how Catholicism was imagined and portrayed in public discourse. ${ }^{73}$ After the Protestant Reformation, there existed a growing body of polemical literature which represented Catholicism as the anti-religion. Arthur Marotti, Lisa McClain, Peter Lake, and Alison Shell are some of the scholars who examine how Catholics appeared in the 'cultural imagination' of Elizabethan England..$^{74}$ Though representations of Catholicism could vary, historians argue that through the repetition of certain tropes and symbols, a language of anti-Catholicism did begin to develop in the post-Reformation period.

Some of the most anti-Catholic writing of this period came from polemical religious tracts which were published for numerous reasons. Many of these writers

\footnotetext{
${ }^{72}$ A comprehensive account of the importance of martyrdom literature to the Catholic community can be found in Anne Dillon, The Construction of Martyrdom in the English Catholic Community, 15351603 (Aldershot: Ashgate, 2002).

${ }^{73}$ Due partly to the impact of the 'New Historicism' of the 1980s, the definition of literature has expanded to include non-traditional texts such as pamphlets, broadsides, sermons, religious tracts and other publications.

${ }^{74}$ Lake and Questier, Anti-Christ's Lewd Hat, 2002; McClain, Lest We Be Damned, 2004; Arthur F. Marotti, Religious Ideology and Cultural Fantasy: Catholic and Anti-Catholic Discourses in Early Modern England (Notre Dame: University of Notre Dame Press, 2005); Tessa Watt, Cheap Print and Popular Piety, 1550-1640 (New York: Cambridge University Press, 1991).
} 
participated in religious debates in order to establish their own theological views and to understand the relationship between English Protestantism and its Catholic past. For many Puritans in the Elizabethan and Jacobean period, anti-Catholicism was a means by which they could establish their support for the English Church while arguing for further reform. ${ }^{75}$ For others, anti-Catholicism was seen as a sign of election and the fight against Rome was part of a larger religious mission. ${ }^{76}$ Anti-Catholicism was also often used to unite Protestants against a common enemy. Sermons by Joseph Hall and Isaac Bargrave indicate a desire to eliminate differences amongst Protestants and to focus on fighting the threat of Catholic conversion. ${ }^{77}$ These anti-Catholic polemics clearly served a range of functions within the Elizabethan period. In addition to these works, there existed a large body of literature that was more nuanced and subtle in its negative representation of Catholics. Though less straightforward in terms of its language of religious hatred, this literature did make a significant contribution to the structuring and nature of anti-Catholic discourse in this period.

In her 1999 work, Whores of Babylon: Catholicism, Gender and Seventeenth Century Print Culture, Francis Dolan examines how a Catholic 'stock character' was created in plays, ballads, pamphlets and newsprint of this period. Often represented as duplicitous and untrustworthy villains, Catholics became symbols of otherness in English society. For example, stories which dealt with domestic conflict often associated insubordinate servants or treacherous wives with Catholicism. ${ }^{78}$ The tale of the servant

\footnotetext{
${ }^{75}$ Anthony Milton, Catholic and Reformed: The Roman and Protestant Churches in English Reformation Thought (New York: Cambridge University Press, 1995), 31.

${ }^{76}$ Ibid., 36.

${ }^{n}$ Ibid., 37.

${ }^{78}$ Francis Dolan, Whores of Babylon: Catholicism, Gender and Seventeenth Century Print Culture (Ithaca: Cornell University Press, 1999), 37.
} 
who secretly served two masters could stand as an allegorical representation of the Catholic subject who claimed obedience both to the monarch and the Pope. Similarly, the wider theme of 'domestic betrayal' could speak to contemporary fears of an internal Catholic rebellion in England. Sometimes the threat was external and Catholicism was associated with the unfamiliar and the foreign. These narratives could take place in, or feature characters from, Catholic nations such as France, Spain and Italy which was common in many revenge tragedies. These stories, Dolan argues, could help English Protestants alienate domestic Catholicism and see it as an external threat which is imported in England from the outside world. ${ }^{79}$

Within many popular narratives, Catholicism was also associated with disorderly women. ${ }^{80}$ Dolan argues that through the association with femininity and female characters, Catholicism was represented as a religion which "inappropriately empowers women, spiritually, symbolically and socially." in Catholicism such as the Virgin Mary, Catholicism could be represented as inverting gender order and thus posing a threat to social norms. ${ }^{82}$ The legend of the female 'Pope Joan' for example, which commonly appeared in anti-Catholic writings of this period, was invoked to "enable Protestants to associate the papacy with...unnatural female domination of the church. ${ }^{.83}$ John Foxe used this image in his within his 1563 Acts and Monuments, as did John Jewel in his 1581 Apology ${ }^{84}$ These representations reflected the specific concerns that Protestant authorities had towards Catholic women, and partially

\footnotetext{
${ }^{79}$ Ibid., 37-38.

${ }^{80}$ Ibid., 4-6.

${ }^{81}$ Ibid., 8.

${ }^{82}$ Ibid., 10-11.
}

${ }^{83}$ Thomas S. Freeman, "Joan of Contention: The Myth of the Female Pope in Early Modern England," in Kenneth Fincham and Peter Lake, eds., Religious Politics in Post-Reformation England (Woodbridge: Boydell Press, 2006), 60-79.

${ }^{84}$ Zlatar, Reformation Fictions, 109. 
explain why these authorities would eventually punish men for the recusancy of their wives. ${ }^{85}$ These women were seen as the individuals who brought Catholicism into the household. They represented the internal, domestic threat that Catholicism allegedly posed to the Protestant state. Especially within the seventeenth century, female figures such as Mary Stuart or Henrietta Maria would come to represent the seductive power of Catholicism and its "insinuation into households and court."

One female image that was commonly linked to Catholicism during the postReformation period was the Whore of Babylon. Images and woodcuts of the Whore of Babylon wearing a papal crown were popular in Protestant Europe, and functioned to associate the Pope with the Anti-Christ. ${ }^{87}$ Like the Whore of Babylon, Catholicism was thought to conceal false religion behind physical beauty. Alison Shell writes that through the use of this image, Catholicism was represented as "superficially enticing but rotten beneath." ${ }^{88}$ The intense visuality, ceremony and ritualism of Catholicism was thought to hide the true, evil character of the religion. Related to this belief was the notion that Catholicism represented idolatry in its worship of the visual. In their study of sermons and religious tracts, Peter Lake and Michael Questier write that idolatry, covetousness and lust were often linked with Catholicism through traditional images of the whore and the usurer. ${ }^{89}$ In a series of several dialogues published in 1581 , John Nicholls associates Catholics and idolatry with sensuality and sexually deviant behaviour. He describes the

\footnotetext{
${ }^{85}$ Haigh, "Catholicism in Early Modern England," 492.

${ }^{86}$ Ronald Corthell et al., eds., Catholic Culture in Early Modern England (Notre Dame: University of Notre Dame Press, 2007), 5.

${ }^{87}$ Representations of the Pope as the Anti-Christ have roots in medieval Europe. Dante, Wycliffe and Savonarola, in addition to Reformation polemicists, commonly evoked this image within their work. For its use in Europe, see Robert Scribner, For the Sake of Simple Folk: Popular Propaganda for the German Reformation (Oxford: Clarendon Press, 1994). For its use in England, see Christopher Hill, AntiChrist in Seventeenth-Century England (London: Oxford University Press, 1971).

${ }_{88}$ Shell, Catholicism, Controversy and the English Literary Imagination, 25-26.

${ }^{89}$ Lake and Questier, Anti-Christ's Lewd Hat, 350.
} 
Catholic clergy, especially the Jesuits, as being involved with "curtezans," "harlottes," and "queanes of the house." 90 Visuality and idolatry were often linked with sexual misbehaviour, and these associations were often invoked in representations of Catholics. Many Protestant polemicists argued that visuality, ceremony and a focus on the body distracted from a truer, inner form of worship. This language not only appeared in strictly religious tracts, but made its way into stories, literature and images which circulated in England. Therefore, the 'Catholic character' which appeared in many representations of this period was often associated with decadence, beauty, and other forms of excessive visuality which were designed to conceal and distract from an evil interior. ${ }^{91}$

The use of these themes of visuality and concealment contributed to associations between Catholicism and secrecy and deceit. Debates in parliament about recusancy often presented Catholics as secretive, rebellious conspirators who posed a threat to domestic security. In the 1581 session of parliament, Sir Walter Mildmay referred to Catholics as 'disobedient', 'corrupt,' 'contemptuous' and the Jesuits specifically as individuals who seek to "...stir sedition to the peril of her majestie and her good subjectes." ${ }^{" 2}$ He warned that Catholics hid priests within their homes and secretly received orders from the Pope to organize rebellions. Debates like this would arise throughout Elizabeth's reign when religious politics and laws of treason were discussed in parliament. At moments when the government felt that an international Catholic power posed a particular threat to English

\footnotetext{
${ }^{90}$ Zlatar, Reformation Fictions, 107.

${ }^{91}$ Shell discusses this trend within theatre, especially within the revenge tragedies of the early seventeenth century.

92 "Sir Walter Mildmay's Speech for Supply," in Proceedings in the Parliaments of Elizabeth I, Vol 1: 1558-1581, ed. T.E. Hartley (Leicester: Leicester University Press, 1981), 504.
} 
security, there was an increased pressure to make this anti-Catholic legislation stronger. ${ }^{93}$ Many anti-papal works argued for stronger penal laws against Catholics during this time. Some of these writers wanted all Jesuit and Seminary priests in England executed while others saw the removal of all recusants from England as the only solution. ${ }^{94}$ There existed a great deal of mistrust and fear towards English Catholics, and to many writers and legislators the threat of Catholic rebellion was a real one.

The language of the penal laws against Catholics of this period offers further proof of the association of Catholicism with deceit and subversion. In the $1585 \mathrm{Act}$ against Jesuits, seminary priests and such other like disobedient persons, Catholic priests are described as having been sent to England to “... stir up and move sedition, rebellion and open hostility...to the great dangering of the safety of her Highness' realms...".95 The 1593 Act against popish recusants discusses "traitorous and most dangerous conspiracies" against Elizabeth by "sundry wicked and seditious persons" who are "spies and intelligencers" that pose a threat to the security of the realm. ${ }^{96}$ These penal laws were designed to identify Catholics, force onto them some degree of conformity to Protestant services, and persecute those who were perceived as threats to Elizabeth's government. Through these acts, Catholics were represented as seditious and rebellious conspirators. In the preambles to these statutes, there was no talk of reformation or conversion. Instead, their declared aim was to restrict and punish Catholics. Draft bills reveal that even harsher measures were contemplated; an early draft of the Act against popish recusants

${ }^{93}$ The year of the Spanish Armada, 1588, and the year of Ridolfi Plot, 1570, are examples of key years when such debates took place. See David Dean, Law-Making and Society in Late Elizabethan England (Cambridge: Cambridge University Press, 1996).

${ }_{94}^{94}$ Milton, Catholic and Reformed, 43.

95 "An Act against Jesuits, seminary priests and such other like disobedient persons," in The Tudor Constitution: Documents and Commentary, ed., G.R Elton (Cambridge: Cambridge University Press, 1960), 424-425.

96 "An Act against popish recusants," in Elton, Tudor Constitution, 427-432. 
proposed that children of Catholics under the age of seven should be taken away from their parents and raised by Protestant authorities. ${ }^{97}$ Though this proposal was amended and eventually rejected, it raised the issue of whether or not the government, and those of the governing elite sitting in Parliament, thought that Catholics could be reformed.

In 1582, writer and preacher George Gifford published $A$ dialogue between a Papist and a Protestant. This work presents a discussion about religion and politics between two Catholic and Protestant scholars. Like many polemicist tracts of this period, Gifford's work makes anti-papal statements and challenges the validity of the Catholic faith. Within this dialogue, as in others produced by John Nicholls and Thomas Rogers in this period, the Protestant tries to use rhetoric and scholarship to convert the misguided Catholic. ${ }^{98}$ In the end however, no such conversion takes place, and the Catholic and Protestant remain fundamentally at odds. Antoinina Zlatar argues that the message Gifford sends through this dialogue is that Catholics are unable to see the 'true religion.' They are blinded by the evil nature of the papacy and they falsely hope for an eventual Catholic restoration in England aided by foreign powers. As a result, they remain traitors to Protestant church and government and no punishment for their deviance can be too extreme. ${ }^{99}$ John Nicholls' 1581 Pilgrimage had a similar message. In describing Catholics, especially Jesuits, as hypocritical, dishonest and secretive, his work undermined Catholic claims of loyalty to the government and reinforced the idea that they were dangerous traitors. ${ }^{100}$ In many cases, the language used in anti-Catholic works was highly militarized and invoked images of battle and war. Anthony Milton writes that

\footnotetext{
97 "Anonymous Journal, $19^{\text {th }}$ February to 10 April, 1593," in Proceedings in the Parliaments of Elizabeth I, Vol 3:1593-1601, ed. T.E. Hartley (Leicester: Leicester University Press, 1981) 69-70.

${ }^{98}$ Zlatar, Reformation Fictions, 121.

${ }^{99}$ Ibid., 121-123.

${ }^{100} \mathrm{Ibid} ., 112-113$.
} 
these characterizations were powerful because they could "easily lend themselves to literal applications to the confessional warfare abroad." ${ }^{101}$ Representations such as these provided the context for penal laws which sought to punish Catholics. ${ }^{102}$ As a result, the perception was that incapable of being reformed, Catholics remained subversive and dangerous individuals. These representations reflected contemporary fears about a Catholic rebellion in England. They also spoke to fears of invasion from foreign Catholic powers supported by the papacy.

As a social and political threat, Catholicism was perceived as the antithesis of the true protestant religion. Much of the imagery and language found within representations of Catholicism presents this dualism between the true and false faiths. ${ }^{103}$ Catholicism followed the anti-Christ whereas Protestantism followed the true Christ. Catholicism focused on ceremony, ritual and clerical control of religious texts, whereas Protestantism focused inwards, emphasized lay scripturalism and simplicity in worship. Catholicism was associated with darkness and false belief, whereas Protestantism was associated with light and truth. Much of the vocabulary commonly used within polemical religious tracts makes these distinctions clear. Terms used when describing Catholics include "blind," "anti-Christ," "heresy," "idolatry" and "darkness" whereas terms used to describe Protestantism are "truth," "light," "Christ" and "holy". ${ }^{104}$ Not only does this reveal a

${ }^{101}$ Examples include John White's 1608 "The way to the true church" as well as Richard Bernard's 1623 "Look beyond Luther," quoted from Milton, Catholic and Reformed, 43.

${ }_{102}$ As Geoffrey Elton writes, "The queen did not want to save souls or make converts; she wanted to protect the safety of her realm." G.R Elton, The Parliament of England 1559-1581 (Cambridge: Cambridge University Press, 1986), 414.

${ }^{103}$ Peter Lake, "Anti-popery: the structure of a prejudice," in Conflict in Early Stuart England: Studies in Religion and Politics, eds., Richard Cust and Ann Hughes (London: Longman, 1989), 72-106.

${ }^{104}$ Francis Dillingham's work makes much use of these terms and may be representative of this trend in other religious tracts of this period. Francis Dillingham, $A$ diswasive from poperie containing twelve effectual reasons, by which every papist, not wilfully blinded, may be brought to the truth and every protestant confirmed in the same. Cambridge: Printed by John Legat. From Early English Books Online 
great deal about how Protestants perceived themselves, but it also illustrates how Catholicism was commonly represented as the negative mirror image of the Protestant church. It has been estimated that between 1558 and 1628 , over 100 works about the 'Romish anti-Christ' alone were published in England by writers such as Arthur Dent, George Gifford, Thomas Rogers and Matthew Sutcliffe. ${ }^{105}$ The image of Catholicism as the anti-Christ was especially important in the Protestant understanding of church history in England. Works such as John Foxe's Acts and Monuments demonstrate how the construction of a Protestant church history in England relied on this perceived battle between the 'true' and 'universal' apostolic church, and the 'false' Romish church presided over by the Pope. ${ }^{106}$

Foxe's work is also representative of how anti-Catholicism was often tied to the construction of an English Protestant national identity within the sixteenth century. Richard Helgerson has identified the Elizabethan period as a time when writers participated in a discourse of English nationalism. He argues that a generation of individuals whose careers spanned from the mid sixteenth century onwards participated in the construction of various English national identities. These men included Shakespeare, Marlowe, Raleigh and other prominent figures from the Elizabethan and Jacobean period. Through their works, they helped to define which individuals were included and excluded from various forms of English nationhood. Helgerson is not the only historian to recognize this period as a time where ideas about nationalism and the individual's relationship to the state began to take hold. Elton has identified the sixteenth

STC/ 6883. http://eebo.chadwyck.com/search/full_rec?SOURCE =config.cfg\&action=byid\&ID= 99847157\&SUBSET $=($ Accessed November 14, 2011) .

${ }_{105}$ Milton, Catholic and Reformed, 93-94.

${ }^{106}$ Ibid., 100-103. 
century as an important period of transition which saw the emergence of a modern sovereign aided by the prerogative of parliament. ${ }^{107}$ The split with Rome and changing role of parliament after the Reformation, as well as the socio-cultural impact of the Renaissance, led to the spread of many ideas concerning nationhood and 'Englishness.' Some have argued that England's sense of self-awareness in this period was aided by its conflicts with the major European nations as well as Catholic Ireland. ${ }^{108}$ Others claim that the influx of immigrants escaping religious persecution from the continent during the Reformation contributed to a sense of 'popular xenophobia. ${ }^{109}$ This xenophobia was not only directed against foreigners but also at English non-Conformists such as radical Puritans and Catholics which heightened a sense of 'otherness.' These considerations have led Steven Greenblatt to label this period as a time where 'self-fashioning' of individual and state identities took place.

In order to understand how the English nation was conceptualized in the sixteenth century, scholars have examined literature to look for individuals, ideologies and groups characterized as possessing traits of foreignness or strangeness. ${ }^{110}$ The creation of any national identity and the process of alienation onstage involve a complex interaction between prejudices and self-perceptions. Any discourse of nationhood is both inclusive and exclusive of certain groups and individuals. Helgerson argues that in both religious and theatrical narratives of this period, there is a self-conscious attempt to construct an idea of the 'English nation' which reveals conflicting ideas of who is allowed to

\footnotetext{
${ }^{107}$ Richard Helgerson, Forms of Nationhood: The Elizabethan Writing of England (Chicago: University of Chicago Press, 1984), 4.

${ }^{108}$ According to Hoenselaars, the Spanish Armada in particular "decisively boosted national awareness and furthered an expression of that awareness in drama." A.J. Hoenselaars, Images of Englishmen and Foreigners in the Drama of Shakespeare and his Contemporaries (London: Associated University Presses, 1992), 26.

${ }^{109}$ Ibid., 27.

${ }^{110}$ See "Introduction" in Hoenselaars for an overview.
} 
participate in this national community. Historians have recognized that there was no singular discourse of nationalism at any point during this period. The construction of any sense of Englishness was an ongoing process which was relied on exchanges "between individual needs, communal interests, and discursive forms," as well as domestic and international political and diplomatic developments. ${ }^{111}$

One of the dominant forms of nationhood which began to ferment in this period was the traditional Protestant 'Whig' narrative of English exceptionalism. ${ }^{112}$ Illustrated in such works as Foxe's Book of Martyrs, England was seen as an 'elect nation' which had a national, Protestant destiny to fulfil against the earthly Catholic Church. ${ }^{113}$ Set in direct opposition to Rome, Foxe's narrative excludes all forms of Catholicism from his understanding of the English nation. Writers such as John Bale, as well as Elizabethan polemicists and preachers, would share in Foxe's construction of English nationalism which was "structured by what was perceived as recurrent Catholic dangers, plots and outrages." 114 The 'othering' of Catholics was a significant part of this discourse about nationalism. Carol Z. Weiner writes that by 1603, "no good Englishman could have defined his national identity without some mention of his distaste for Rome."115

${ }^{111}$ Helgerson, Forms of Nationhood, 301.

112 This narrative characterized England as a progressive, Protestant nation where parliament and monarch worked in conjunction to represent the English people. This stood in sharp contrast to the perceived absolutism of Catholic nations on the continent. Herbert Butterfield, The Whig Interpretation of History (London: G. Bell and Sons, 1950).

${ }^{113}$ This belief would become more popular in the later seventeenth century after the English civil wars and the Glorious Revolution. William B. Haller, Foxe's Book of Martyrs and the Elect Nation (London: J. Cape, 1963).

${ }_{114}$ Arthur Marotti, Catholicism and Anti-Catholicism in Early Modern English Texts (New York: St. Martin's Press, 1999), 131. Marotti recognizes the Gunpowder Plot, the Irish Rebellion and the Popish plot as three particular "moments of crisis" in the seventeenth century that allowed this Protestant view of English nationhood to take hold in the seventeenth century.

${ }^{115}$ Carol Z. Weiner, "The Beleaguered Isle: A Study of Elizabethan and Early Jacobean AntiCatholicism," Past and Present 51 (1971), 27. 
Excluding Catholics from an ideology of nationhood was not a straightforward or simple process. Many individuals recognized that their ancestors, as well as many of their neighbors, were Catholic. As well, negative representations of Catholicism rarely translated into any direct violence against Catholic communities, though it did provide a context for the penal laws of this period. ${ }^{116}$ Nevertheless, there did exist ideas about who participated in the "English nation," and more often than not Catholics were perceived as outsiders. As Arthur Marotti writes, “...the rhetoric of anti-Catholicism was used to create a narrative...in which English identity could be fixed as Protestant and English nationhood could be distinguished from that of continental Catholic states." ${ }^{117}$ Many plays of this period, such as Christopher Marlowe's Massacre of Paris or Thomas Kyd's The Spanish Tragedy participate in this discourse of nationalism by alienating Catholics and representing them as threats to national security.

In the post-Reformation period, Catholics were represented as rebellious, idolatrous and secretive individuals. They were viewed as threats to both the social order and political stability of Elizabethan England. This threat was internal and external, domestic and foreign, both strange and familiar. Many of these representations undoubtedly alienated Catholics within Elizabethan society. However, these attempts to create distance from the Catholic 'other' only serve to illustrate that Catholicism remained a central part of the social reality of this period. Elizabethans were constantly interacting with Catholics at both the local as well as international level. The Protestant Reformation in England did not signal the demise of Catholicism within the early modern period. Instead, it created a new social and political environment in which several

\footnotetext{
${ }^{116}$ Milton, Catholic and Reformed, 44.

${ }^{117}$ Marotti, Catholicism and Anti-Catholicism, 132.
} 
religious groups had to coexist, and reformulate their identities in relation to one another. Nevertheless, a culture of anti-Catholicism did exist which would provide one of several contexts in which one can read the works of Christopher Marlowe. 


\section{CHAPTER TWO: Christopher Marlowe and the Elizabethan Stage}

\subsection{Christopher Marlowe: Critical Perspectives}

Elizabethan playwright Christopher Marlowe's literary talent was recognized by contemporaries such as Thomas Heywood and Henry Petowe, as well as modern writers William Hazlitt and James Broughton, the latter of which celebrated Marlowe as one of "the first class of dramatic writers" of the Renaissance period. ${ }^{118}$ However, interest in Marlowe's literary career only truly came to the forefront in the nineteenth century when there existed a growing fascination with the study of Renaissance plays. In this period, Christopher Marlowe was recognized as one of several 'major' English writers and his works were compared to contemporaries such as Shakespeare, Milton and Johnson. His poetry and plays were reprinted continuously and scholars such as James Broughton, J.P Collier and Alexander Dyce began to examine sources for Marlowe's life, bringing to light biographical information that was previously unknown. ${ }^{119}$ Many of these Victorian critics saw Marlowe as a tragic, romantic figure whose contempt for authority and mockery of traditional social values is laced throughout his plays. Others saw Marlowe as "an artistic moral reformist" whose idealism was corrupted by the alleged hypocrisy of the Renaissance period. ${ }^{120}$

\footnotetext{
${ }^{118}$ Patrick Cheney, "Introduction: Marlowe in the twenty-first century," in The Cambridge Companion to Christopher Marlowe, ed. Patrick Cheney (Cambridge: Cambridge University Press, 2004) 8.

${ }^{119}$ Collier was known to have manipulated certain documents in his interpretation of Marlowe's character. Nevertheless, these writers did provide information on Marlowe's life that has provided a basis for modern Marlovian biographies.

${ }^{120}$ Dabbs goes into great detail about Victorian perspectives of Marlowe's character and how they reflected the political and social developments of the nineteenth century. Thomas Dabbs, Reforming Marlowe: The Nineteenth-century Canonization of a Renaissance Dramatist (Lewisburg: Bucknell University Press, 1991).
} 
In the twentieth century, Marlovian scholarship continued to grow with an emphasis on his biography and the details surrounding his sudden and mysterious death.

\section{Paul Kocher's 1946 Christopher Marlowe: A Study of his Thought, Learning and}

Character as well as Harry Levin's The Overreacher remain two influential monographs from this period which address Marlowe's life and controversial reputation amongst contemporaries. ${ }^{121}$ These biographical works have participated in debates about Marlowe's alleged atheism, his career as a spy and his ambiguous religious beliefs. In the 1960s, critics increasingly began to focus on the relationship of Marlowe's texts to matters of sexuality, politics, religion and the literary and theatrical culture of the sixteenth century. ${ }^{122}$ In 1992, Charles Nicholl published The Reckoning, examining Marlowe's involvement in the diplomatic underworld of Elizabethan politics. The early characterization of Marlowe as a subversive figure has also continued and is visible in the works of Stephen Greenblatt and Mark Burnett. In addition to studying the biographical details of Marlowe's life, modern scholarship also emphasizes Marlowe's relationship to his environment and how his plays participate in sixteenth century political, religious and cultural debates. Sara Munson Deats, David Riggs, Constance Brown Kuriyama, and David Bevington have all focused on Marlowe's role in English Renaissance life as well as his relationship to other playwrights of this period. ${ }^{123}$

${ }^{121}$ Harry Levin sees Marlowe as the archetypical renaissance figure caught between the tradition of the old world and the humanism of the new. He made strong links between Marlowe and the protagonists of his work. Though it remains an influential work, Levin has been criticized for making too much of a connection between Marlowe's personality and his protagonists. Harry Levin, The Overreacher: A Study of Christopher Marlowe (Boston: Beacon Press, 1964).

${ }_{122}$ Ibid., 10.

${ }^{123}$ Constance Brown Kuriyama, "Marlowe, Shakespeare and the theoretically irrelevant author," in Placing the Plays of Christopher Marlowe, eds., Sara Munson Deats and Robert Logan (Aldershot: Ashgate, 2008), 185-192. 


\subsection{Marlowe's Life}

The existing sources on Marlowe's life remain incomplete and scattered, leaving only a partial portrait of the Elizabethan playwright. An enigma even during his own day, Marlowe was accused by contemporaries of being a murderer, an atheist, a homosexual and a government spy working for Sir Francis Walsingham. ${ }^{124}$ Arrested for counterfeiting and for assault on more than one occasion, Marlowe remained a controversial figure during his time. Christopher Marlowe was born in 1564 to a shoemaker in Canterbury. After attending the King's School in Canterbury, Marlowe entered Corpus Christi College, Cambridge in December of 1580 . He completed his Bachelor's Degree in July of 1584 and remained at Cambridge to complete his Masters. During this period, Marlowe was noted for his frequent absences and when it came time to receive his Masters, Cambridge authorities were reluctant to award him his degree. At this time, rumours began to circulate that Marlowe had defected to a Catholic seminary at Rheims. Others thought that Marlowe had recently become a part of Elizabeth's secret service. In June 1587 , the Privy Council wrote a letter to the Cambridge authorities explaining his truancy by stating that Marlowe "had done her Majesty good service... in matters touching the benefit of his country." 125 Many historians agree that it is likely that Marlowe was working as an intelligence operative during this period. A significant part of Marlowe's social circle during his adult life, including Richard Baines, Thomas Watson and Thomas Walsingham, were known to have worked for the Elizabethan government at one point or another.

\footnotetext{
${ }^{124}$ David Riggs, "Marlowe's Life," in The Cambridge Companion to Christopher Marlowe, 2425. ${ }^{125}$ Ibid., 29.
} 
In the late 1580 s, Marlowe began writing plays for Lord Strange's acting company, producing Dido Queen of Carthage, Tamburlaine parts one and two, The Jew of Malta, Doctor Faustus, Edward II and The Massacre at Paris by 1592. Tamburlaine was the only play published during Marlowe's lifetime, with the others published after his death. Marlowe also wrote five known poems though none of them made it into print during his lifetime. It is likely that during this period, Marlowe may have also continued his work for the secret service either as a messenger or as a spy. ${ }^{126}$ Within this time, Marlowe also had several run-ins with the law and was arrested for sword fighting, counterfeiting and assault. In May of 1593, Marlowe was fatally stabbed in the eye while fighting over 'the reckoning,' or bill of food, at an inn at Deptford. Ingram Frizer, who was responsible for killing Marlowe, claimed self-defence and was acquitted on charges of murder at the official inquest. The circumstances surrounding Marlowe's death have spawned several conspiracy theories, many of which deal with the three men who were with Marlowe the night he died and their connections to the Elizabethan secret service. Some theories also claim that Marlowe was never killed at all, and that he faked his death for reasons connected to espionage. ${ }^{127}$ In either case, Marlowe's literary career ended at age twenty-nine though many of his works continued to be performed until the closing of the theatres in 1642.

Scholars who have examined the source on Marlowe's life have also become interested in any information that may provide a greater understanding of his religious

\footnotetext{
126 Within his work, "The Reckoning," Charles Nicholl goes into significant details about Marlowe's connections to the secret service, as well as the time he may have spent abroad in France and the Netherlands working for the government. He claims that Marlowe was murdered on the orders of the Earl of Essex. Charles Nicholl, The Reckoning: The murder of Christopher Marlowe (London: J. Cape, 1992).

${ }^{127}$ J.A. Downie, "Marlowe: Facts and Fictions." In Constructing Christopher Marlowe, eds. J.T. Parnell \& J.A. Downie (Cambridge: Cambridge University Press, 2000), 13-30.
} 
views. In addition to being accused of Catholicism for his alleged time in Rheims, Marlowe was branded an atheist by several of his contemporaries. In 1592, playwright Robert Greene, in his Groatsworth of Wit, referred to Marlowe as the one "who hath said... like the foole in his heart, There is no God...". ${ }^{128}$ In May 1593, shortly before Marlowe's death, his fellow lodger Thomas Kyd was arrested for writing seditious and anti-Christian literature against foreigners. Kyd claimed that the heretical text, which contained several references to Tamburlaine and The Jew of Malta, belonged to Marlowe. This accusation reinforced Marlowe's reputation as a blasphemer and possible atheist. Though he was eventually arrested for allegedly publishing the text, Marlowe died May 30 of 1593 , shortly before he was to attend trial for charges of heresy. Around the time of his arrest, Richard Baines sent a letter to the Privy Council further alleging that Marlowe was an atheist. ${ }^{129}$ The charge of atheism was a dangerous one in early modern England and though several contemporaries claimed that Marlowe was a religious deviant, it remains unclear what his actual spiritual beliefs truly were.

Many historians and biographers have attempted to reconstruct Marlowe's religious views in order to understand how they may have impacted his writings. Scholars have searched his plays and poems looking for insight into his spirituality and religious affiliations. Within his works, Marlowe tends to generally criticize all religions. The Massacre at Paris criticizes religious violence and fanaticism while The Jew of Malta parodies Christian, Muslim and Jewish institutions. Faustus and Tamburlaine both transgress God in their ambitious quests for fame and glory, blaspheming against

\footnotetext{
${ }^{128}$ Paul Harold Kocher, Christopher Marlowe: A study of his thought, learning and character (New York: Russell, 1946), 23.

${ }_{129}$ Ibid., 26-7. Baines provided parliament with a "note containing the opinion of one Christopher Marly concerning his damnable judgement of religion, and scorn of God's word."
} 
traditional Christian values during the process. Though religious controversies and topics often appear within his works, it does not seem as if Marlowe has any straightforward agenda when discussing spiritual matters. Religion was an integral part of sixteenth century English society, bleeding into all aspects of political and family life; therefore, it only seems appropriate that it would somehow appear in Marlowe's works as 'raw material' for his artistic endeavours. ${ }^{130}$ Baptized as a Protestant, Marlowe was expected to become a minister once he completed his education at Cambridge. While studying for his degree, it was likely that Marlowe learnt a great deal of Christian theology and especially became familiar with the intense debate over Calvinism, and particularly free will and predestination, that were taking place within Cambridge at this time. ${ }^{131}$ Whatever Marlowe's religious views were, it is problematic to assume a direct connection between what he may have believed and how religion is represented within his works. As Michael Hattaway writes, "literary texts provide evidence not necessarily of the realities of the period nor of the opinions of their authors but rather of the imaginative and ideological constructions or mentalities of the period."132

\subsection{The Elizabethan Theatre}

The earliest commercial theatre, the Red Lion, opened just outside of London in 1567. Others quickly appeared in the following decades including the Swan, the Globe,

${ }^{130}$ I borrow the term 'raw material' from Alison Shell, Shakespeare and Religion (London: Methuen, 2010), 19.

131 Pinciss explores Marlowe's university career and exposure to Calvinism thoroughly within his work G.M. Pinciss, "Marlowe's Cambridge Years and the Writing of Doctor Faustus," Studies in English Literature 33 (1993), 249-264.

${ }^{132}$ Michael Hattaway, "Drama and Society," in Cambridge Companion to English Renaissance Drama (Cambridge: Cambridge University Press, 2003), 97. 
as well as the Fortune theatre. ${ }^{133}$ The Rose theatre, where many of Marlowe's play were performed, was built south of London in 1587 by theatre entrepreneur Phillip Henslowe. Though it was abandoned in 1605 , the Rose remained the central location for performances by Lord Strange's and Lord Admiral's men of whom Edward Alleyn, one of the most famous Elizabethan actors of this period, developed a reputation for playing Marlowe's protagonists. Though it has been established that the Rose was a thirteen-sided polygon, the exact layout and measurements of the theatre have been debated since its excavation began in $1989 .{ }^{134}$ According to David Bevington, it is likely that the Rose provided the raised platform, two doors and tiring house that most performances of Doctor Faustus required. ${ }^{135}$ The stage itself likely retained the flexibility and simplicity that most playhouses in this period tended to have, allowing for numerous performance possibilities during this time. ${ }^{136}$

Though most playhouses were built in the Elizabethan period, the tradition of playmaking long predated the establishment of these permanent spaces in which to act. Troupes of players often travelled around England performing for audiences in major towns and cities. Between 1530 and 1580 , there were over fifty noblemen's troupes known to travel around England and perform. ${ }^{137}$ During this period however, the government began to crack down on street-players which contributed to the establishment

${ }^{133}$ R.A Foakes, "Playhouses and Players," Cambridge Companion to English Renaissance Drama (Cambridge: Cambridge University Press, 2003), 2-3.

${ }^{134}$ Eccles provides a clear overview of what information the archeological dig has been able to provide thus far. Christine Eccles. The Rose Theatre (New York: Routledge, 1990).

${ }^{135}$ In this case, Bevington refers to performances of the A-text. It is possible that the more elaborate B-text would have required a different setting. Directions within the B-text of Doctor Faustus require characters to enter 'from above' indicating the need for a balcony or gallery atop the main stage. Bevington, "The Performance History," 43-46.

${ }^{136}$ Ibid., 44.

${ }^{137}$ Paul Whitfield White, Theatre and Reformation: Protestantism, Patronage and Playing in Tudor England (Cambridge: Cambridge University Press, 1993), 12. 
of permanent playhouses. ${ }^{138}$ In this period, the commercial theatre became a successful economic enterprise, and a central feature of Elizabethan culture. These theatres in turn provided new opportunities for playwrights, such as the 'University Wits,' a group of intellectuals educated at Cambridge who became writers instead of following more traditional career paths expected of a university graduate. ${ }^{139}$ The Elizabethan period remains significant as it was a time playhouses, playwrights and acting troupes came together and redefined the culture of performance.

Many historians have examined the locations of these early theatres and the significance of their placement immediately outside the city of London. The 'liberties,' where many of these theatres stood, were not neutral spaces. Scholars such as Steven Mullaney have argued for the significance for these marginal spaces which stood apart from the confines of the city and thus held the potential for "ambivalent spectacle and cultural license." ${ }^{, 140}$ Though geographically part of the metropolis, the liberties were outside of direct control of the Lord Mayor and the city authorities. Located outside the ancient walls of the city, the liberties served as a liminal space that was both a part of, and yet far removed from, the political and social boundaries of London. As a part of the fringes of London's boundaries, the liberties contained taverns, brothel houses, bearbaiting arenas and places in which criminals were executed. These spaces were essentially ambivalent and reflected all that had physically and socially been pushed to the fringes of 'normative' society. Mullaney argues that the marginality of the liberties allowed playhouses to experiment with traditional Elizabethan rituals and customs. As a result, the medium and location of the theatre increased the potential of a play for

\footnotetext{
${ }^{138}$ Foakes, "Playhouses and Players," 2-3.

${ }^{139}$ Stevie Simkin, Marlowe: The Plays (Houndmills: Palgrave, 2001), 226-227.

${ }^{140}$ Mullaney, The Place of the Stage, 23.
} 
subversive representation. Companies would advertise their plays through playbills placed throughout the city but it may be significant that playgoers would have to leave the confines of the city walls in order to move into this essentially ambiguous place.

Theatre companies within this period were comprised of all male actors. These companies tended to organize themselves much like guilds with nine to twelve members, including sharers, hired men and apprentices. The principal actors themselves were often shareholders whose personal welfare depended on the success of individual performances. ${ }^{141}$ Many actors of this period tended to be poor individuals, though some men such as Edward Alleyn did achieve celebrity status. ${ }^{142}$ Most of the plays produced at this time were written for a specific playing company, so playwrights could tailor their characters with the skills of certain actors in mind. ${ }^{143}$ Doubling was a common practice on-stage amongst actors who commonly played more than just one role during a performance. ${ }^{144}$ There were no 'directors' within these companies, therefore, actors had a good deal of autonomy in deciding how the performance was to be structured and staged. A prompter or book-keeper who held a copy of the text often supervised rehearsals along with several stage keepers who functioned as his assistants. Playwrights surrendered the legal rights to their work when they sold them to playing companies. As a result, the play would become the property of the acting troupe and the author may have had no say in how the text was to be performed. ${ }^{145}$ The written copy of the play itself was very fluid,

${ }^{141}$ Foakes, "Playhouses and Players," 39.

142 Gerald E. Bentley, Profession of Player in Shakespeare's Time, 1590-1642 (Princeton: Princeton University Press, 1984), 4-6. Bentley provides an extensive list within his appendix of every recorded actor within this period.

${ }^{143}$ Ibid., 206-208.

144 Emma Smith, The Cambridge Introduction to Shakespeare (Cambridge: Cambridge University Press, 2007), 9.

${ }^{145}$ Andrew Gur and Mariko Ichikawa, Staging in Shakespeare's Theatres (Oxford: Oxford University Press, 2000), 21. 
and actors commonly forgot their lines and added their own during performances. Many staging companies often performed two or three plays a week. The diary of theatre owner Phillip Henslowe indicates that the Admiral's Men staged a new play almost every day, performing fifteen works within a twenty-five day period. ${ }^{146}$ This suggests that it would be incredibly difficult for any actor to thoroughly memorize his part and remember it accurately for performance. As a result, improvisation in both speech and gesture was a common feature of performance. In fact, it was not uncommon for some playwrights to complain about how far the work of players departed from their original texts. ${ }^{147}$

In addition to having considerably autonomy over their spoken lines, actors also supervised their own movements on stage, deciding when and how they were to enter and exit a scene. No fixed script existed within this period which detailed how actors were to move their bodies on stage or with which tone and pitch they used in their vocal projections. As a result, the movement of actors in relation to one another, to physical objects on stage and to the audience could vary significantly within different performances. Common conventions of acting are difficult to describe without knowing the everyday gestural language of Elizabethans. However, efforts have been made to understand how actors may have moved within this period. David Bevington argues that the gestural language of actors was based on the assumption that certain emotions were caused by underlying physiological processes. This reflected the sixteenth century understanding of where emotions came from and how the body produced fixed reactions to certain phenomena. For example, all individuals were understood to experience anger in the same way; therefore, the expression of this emotion could be similar for all actors

\footnotetext{
${ }^{146}$ Hattaway, "Drama and Society," 51-53.

${ }^{147}$ A. R. Braunmuller, "The Art of the Dramatist," in The Cambridge Companion to English Renaissance Drama (Cambridge: Cambridge University Press, 2003), 59.
} 
and involve contorted facial movement and certain gestures. However, Bevington recognizes that though sixteenth century actors may have understood all emotions to be experienced similarly, they could still manipulate the expression of these feelings. ${ }^{148}$ It remains a mystery what internal processes and theatrical conventions motivated actors to move a certain way. As a result, it is problematic to make any generalizations about gestures and movements because they could be so nuanced and inconsistent throughout various productions. Performances were not organized in a structured manner and as a result, there was never any stable meaning conveyed through performance during this period. Postures, movements, facial expressions and gestures could vary so considerably within different stagings of the same play that it is unlikely any two audiences ever viewed the exact same performance.

Though historians have little information on the staging conventions of Elizabethan plays, there does exist a body of literature detailing some of the elements of performance which include costumes, makeup, music and the use of lighting. Costumes were commonly employed within most productions, though they were often times more simplistic than elaborate, as well as more emblematic than realistic. Fancier costuming could also be used; Henslowe's diary indicates that considerable funds were spent to acquire fancy clothing and materials for the stage. Costuming often signified social rank, occupation, gender and marital status. Moreover, clothing could be used to establish social and political authority, create illusions and disguises or to demonstrate metamorphosis. ${ }^{149}$ Costuming could also provide a wealth of information about the

\footnotetext{
${ }^{148}$ David M. Bevington, Action is Eloquence: Shakespeare's Language of Gesture (Cambridge, Mass: Harvard University Press, 1984), 68-96.

${ }^{149} \mathrm{Jean}$ MacIntyre, Costumes and scripts in Elizabethan theatre (Edmonton: University of Alberta Press, 1992).
} 
relationships between characters as well. Similarly, makeup could be used to disguise or highlight an actor's facial features. Clothing and makeup were two ways in which the body of the actor could be manipulated and inscribed with meaning during a performance.

Other elements of performance used within Elizabethan productions included material objects and props. ${ }^{150}$ Sceneries and backdrops onstage were uncommon but large props such as tables or thrones could be used to establish a particular setting. Musical instruments such as bells, trumpets and drums were often used to indicate the passage of time, the entrance of a regal figure or an approaching battle. ${ }^{151}$ Fireworks and guns could also be used to create special effects for the audience. Because theatre companies had such a large repertory, it is unlikely that a great deal of effort could be spent on creating elaborate and detailed stage settings; therefore, actors were responsible for creating much of the scene through blocking and gesturing. ${ }^{152}$ It is unclear precisely which aesthetic choices and conventions were popular onstage. However, it seems that simplicity in both design and stage presence was most common in this period. The exact positioning of actors and props in relation to one another within specific plays also remains unavailable to historians. The play texts themselves do reveal some information about the presence and location of objects onstage. Gestural language used by the playwright provides some

${ }^{150} 1$ use both 'prop' and 'object' here. Patrice Pavis writes that the term 'prop' is often bound up with the idea that it is a secondary tool manipulated with the actor, whereas 'object' is seen as anything onstage that can be used by actors. Patrice Pavis, Analyzing Performance: Theatre, Dance and Film (Ann Arbor: University of Michigan Press, 2003), 186.

${ }_{151}$ Hattaway, "Drama and Society," 59-61.

${ }^{152}$ Bevington, Action is Eloquence, 71 . 
insight into how actors may have handled objects and behaved onstage; however, much of the information that can be derived from texts remains inconsistent and ambiguous. ${ }^{153}$

The stage itself was often rectangular and situated on a raised platform. A play like the a-text of Doctor Faustus would require a simple stage with two doors, and very little scenery to set the stage. ${ }^{154}$ Seats were located around the front and both sides of the stage, as well as on semi-circular balconies. In the playhouse, there was little physical division between the audience and the actors. Both shared the same light and open air, and actors would often speak directly to audience members. ${ }^{155}$ Spectators also remained aware of their fellow audience members to whom they were often in very close proximity. The almost circular layout of the theatre meant that theatre-goers could very easily view one another and observe the reactions of those around them. ${ }^{156}$ As a result, spectatorship was very much a participatory act and a very precarious boundary existed between the illusion created onstage and the reality of viewership within audience spaces.

Audiences within these playhouses could often be representative of London's social and economic diversity. Historians have examined and debated the extent to which these commercial theatres were inclusive of different social orders in this period. Ann Jennalie Cook has argued that the majority of Elizabethan playgoers were from the privileged classes whereas Martin Butler has asserted that the low cost of playgoing in the late sixteenth century allowed for considerable social diversity in these playhouses. ${ }^{157}$ Overall, it seems that certain plays and playhouses may have appealed to different

${ }^{153}$ Alan C. Dessen, Elizabethan Stage Conventions and Modern Interpreters (New York: Cambridge University Press, 1984), 19.

ist Bevington, "The Performance History," 43.

${ }^{155}$ Foakes, "Playhouses and Players," 23.

${ }^{156}$ Gurr and Ichikawa, Staging in Shakespeare's Theatres, 4-5. Gurr and Ichikawa refer to this as 'self-conscious grouping.'

${ }^{157}$ Ann Jennalie Cook, The Privileged Playgoers of Shakespeare's London 1576-1642 (Princeton: Princeton University Press, 1981). 
audiences, and that the diversity present in one audience may not have been reflected within another. For example, many hall playhouses like Blackfriars tended to cater to high markets. ${ }^{158}$ As well, the costs of playgoing did not remain consistent within this period, and seem to have risen during the seventeenth century which may have excluded certain individuals from attending plays at different points in time. Within almost all playhouses, seats within the arena and the galleries were more expensive than the cost of standing in the yards. As a result, there was a literal hierarchy of social standing as the most expensive seats were in the balconies and the cheapest around the stage. If filled to their capacity, these playhouses could hold up to three thousand spectators at any given time. ${ }^{159}$ It has been estimated that up to twenty-five thousand people attended performances in London every week from 1580-1640. Spectators were expected to remain in the section of the auditorium that they paid for, but they had the freedom to move about if their view was obstructed. As a result, one could experience a performance several different ways by constantly shifting their perspective of the stage and the other audience members around them.

Many efforts have been made to understand the social composition of playgoers. These theatres were located just outside of London, and urban elites, middling classes as well as the laboring poor could cross the Thames to attend a performance. Artisans, merchants, manufacturers, laborers and a high proportion of women were known to frequent theatres. Peddlers were also known to commonly attend performances in order to sell food and beer to other audience members. ${ }^{160}$ Andrew Gurr writes that playgoing may

\footnotetext{
${ }^{158}$ Andrew Gurr, Playgoing in Shakespeare's London (New York: Cambridge University Press, 1984) 79 .

${ }^{159}$ Gurr and Ichikawa, Staging in Shakespeare's Theatres, 34-35.

${ }^{160}$ Ibid., 5.
} 
have had a unique appeal to illiterate populations in particular since spectatorship did not require knowledge of the written word. ${ }^{161}$ Historians have attempted to reconstruct the social composition of audiences in order to understand if the activity of playgoing appealed to any specific types of individuals over others. However, as Thomas Cartelli notes, in spite of recent attempts, “...we are still far as ever from any authoritative conclusion regarding the mental and social composition of Elizabethan playgoers."162 Furthermore, Cartelli argues,

[ It is] less important to identify who comprised the Elizabethan audience, from what social classes...they were drawn, than it is to determine what motivated people of all classes to attend plays, what effects plays might have had on them, and what such people brought to their successive acts of playgoing. ${ }^{163}$

The danger in focusing on which social classes frequented theatres more than others is that one risks creating "predetermined, socially constructed categories" in order to organize and understand audience responses and experiences. ${ }^{164}$

From what scholars have been able to reconstruct, there does not appear to be a specific type of mindset that attracted certain individuals to playhouses. Attempts to define characteristics of the 'playgoing public' versus the 'non-playgoing public' risks creating an assumption that individuals who frequented the theatre possessed some quality that others did not. A multitude of ideas and beliefs were expressed onstage including those that were traditional and orthodox, as well as those that were potentially radical and subversive. As a result, plays could have appealed to a variety of people.

${ }^{161}$ Gurr, Playgoing in Shakespeare's London, 50-55.

${ }^{162}$ Thomas Cartelli, Marlowe, Shakespeare and the Economy of Theatrical Experience (Philadelphia: University of Pennsylvania Press, 1991), 41.

${ }^{163}$ Ibid., 47-8.

${ }^{164}$ Ibid., 47. 
Therefore, it is problematic to try and create the fixed identity or the mental composition of the 'playgoer.'

\subsection{Anti-theatricalism}

As a growing public pastime, the act of playgoing began to attract considerable criticism during the later sixteenth century. Anti-theatrical tracts began to appear in the 1570s and they reveal many of the social and religious tensions that existed within Elizabethan England. Criticisms of the theatre ranged from religious attacks about the value of representation to social and moral concerns about crowded public spaces. The existence of these tracts attests to the anxieties that many held about the rise of this popular new medium. The commercial theatre was a relatively new social and economic institution, and anti-theatricalists questioned the value and consequences of playgoing. Much of the criticism which surrounded the theatre dealt with the nature of illusion and value of 'pretending' onstage. Many anti-theatricalists criticized the illusory nature of theatre, and accused actors of hypocrisy for pretending to be something that they were not. ${ }^{165}$ This was particularly true of male actors who played female parts. Critics would attack the fluidity of sexual identities on-stage, often claiming that male actors were effeminized by dressing up as women. Some even feared that male actors risked becoming attracted to other males through their performance. ${ }^{166}$ In the Elizabethan period, the colors, style and materials of clothing often marked the sharp distinctions between different orders of society. The existence of the sumptuary laws during the Tudor period attests to the importance placed on proper dress and clothing as markers of

\footnotetext{
${ }^{165}$ Shell, Shakespeare and Religion, 40.

${ }^{166}$ Laura Levine, Men in Women's Clothing: anti-theatricality and effeminization, 1579-1642 (New York: Cambridge University Press, 1994).
} 
social status. The ability of actors to manipulate costumes and dress above or below their station was interpreted as a threat by those who feared that traditional social boundaries were attacked through performance. In his 1582 tract, Plays Confuted in Five Actions, Stephen Gosson writes that theatre is inherently corrupt because it is only able to entertain through falsehood and deceit. He writes that the act of pretending is blasphemous against both God and nature. ${ }^{167}$ Gosson, like other anti-theatricalists, questioned the consequences of creating and participating in illusion. Their writings are indicative of an anxiety that surrounded the ability of actors to transcend one identity and easily adopt another.

The strongest opposition to theatre often came from often-published Protestant authors who feared the power of representing the sacred on-stage, claiming that references to religion treated Christianity profanely. References to Greco-Roman deities and paganism were perceived as equally dangerous because they showed reverence to false gods. ${ }^{168}$ Some anti-theatricalists accused the theatre of idolatry, claiming that the ritual and spectacle on-stage mirrored practices of Catholic worship. ${ }^{169}$ The language of anti-Catholicism often appeared in these texts, and an association was drawn between the alleged superstition of the 'theatre' and spectacle visible in Catholic churches, and that which was represented on the secular stage. While it is easy to insist on a link between Puritanism and anti-theatricality due to the general sixteenth century Puritan criticism of non-religious activities and pastimes, this assumption becomes problematic in the case of some, such as Thomas Middleton, who recognized the value of theatre and indeed

${ }^{167}$ Stephen Gosson, "Plays Confuted in Five Actions," in Shakespeare's Theater: A Sourcebook, ed. Tanya Pollard (Oxford: Blackwell Publishing, 2004), 93-95.

${ }_{168}$ Anthony Munday, "A Second and Third Blast of Retreat from Plays and Theatre," in Shakespeare's Theater: A Sourcebook, ed. Tanya Pollard (Oxford: Blackwell Publishing, 2004), 73.

${ }^{169}$ For a full exploration of this discussion, please see below. 
himself became a successful playwright during this time. ${ }^{170}$ Nevertheless, the representation of different Christian images and beliefs on-stage was controversial during a period where religious tension and ambiguity persisted on so many levels. This ambiguity was often reflected onstage, and many writers feared the consequences of treating religious beliefs, rituals and materials as objects for theatrical art. However, some writers did recognize the value of theatre in propagating 'orthodox' religious views. For example, John Foxe and John Bale both produced religious plays and saw them as an effective means of transmitting Protestant ideas amongst theatregoers. Foxe and Bale saw the theatre as an essential weapon in fighting the superstition of the old religion. ${ }^{171}$

Other religious objections towards the theatre dealt with the fact that playgoing often competed directly with the pulpit for attendance, as well as a source for providing moral authority. ${ }^{172}$ Churchgoing and playgoing have been recognized as two very similar social activities. Both have been described as involving "a communal affective response to an aesthetically staged event." ${ }^{\text {173 }}$ In his 1580 work, $A$ Second and Third Blast of Retreat from Plays and Theatres, Anthony Munday criticized the practice of staging performances on the Sabbath, describing how the stage lured individuals away from the religious activities they were supposed to participate in on Sundays and Holy Days. ${ }^{174}$ In his 1600 The Overthrow of Stage Players, John Rainolds complained that the stage competes directly with sermons for the allegiance of even the most privileged members

${ }^{170}$ Shell, Shakespeare and Religion, 32.

${ }^{171}$ Paul Whitfield White discusses the Reformation theatre in Theatre and Reformation: Protestantism, Patronage and Playing in Tudor England (Cambridge: Cambridge University Press, 1993). 172 Tanya Pollard, "Introduction," in Shakespeare's Theater: A Sourcebook, ed. Tanya Pollard (Oxford: Blackwell Publishing, 2004), xiii.

${ }^{173}$ David Hillman, review of The Culture of Playgoing in Shakespeare's England: A Collaborative Debate, by Anthony B. Dawson and Paul Yachnin, Shakespeare Quarterly 54 (2003), 207209.

${ }^{174}$ Munday, "A Second and Third Blast of Retreat," 71-72. 
of society. ${ }^{175}$ Many anti-theatricalists feared that playgoers would begin to identify with stage characters and therefore mimic their behavior. Munday often complained that plays about love incited feelings of lust and posed a threat to chastity, as playgoers would model their actions on what they observed onstage. ${ }^{176}$ The fear amongst these writers was that church authorities would no longer be recognized as authority figures, and instead actors would be regarded as models of correct living.

In addition to religious objections to the practice of playgoing, there were also secular objections to the theatre by moralists of this period, many of whom feared the possibility of public disorder amongst crowds. These writers argued that the noise and traffic caused by large crowds attending performances produced the risk of rioting. This fear of gathering masses was conflated by London's rising population at this time, and reflects a general unease with the social and demographic disruption caused by the increased number of the city's inhabitants. ${ }^{177}$ These critics also cited the growing risk of infections and disease amongst large groups of gathering people which was a social reality that led to the closing of theatres during outbreaks of plague epidemics. ${ }^{178}$ Others cited the presence of prostitutes, pickpockets, con artists and beggars amongst audiences, questioning the safety and moral purity of theatregoers. ${ }^{179}$ Some critics feared that the lure of entertainment during the working day would lead workers and apprentices from their jobs and to the theatre, promoting idleness and decreasing productivity. ${ }^{180}$

\footnotetext{
${ }^{175}$ Cartelli, Marlowe, Shakespeare and the Economy of Theatrical Experience, 53.

${ }^{176}$ Munday, "A Second and Third Blast of Retreat," 77.

177 Janet Clare, 'Art made tongue-tied by authority:' Elizabethan and Jacobean Dramatic Censorship (New York: Manchester University Press, 1990), 9.

${ }^{178}$ These years were $1581-82 ; 1592-93 ; 1603-04 ; 1608-09 ; 1609-10 ; 1623 ; 1630 ; 1636 ; 1640$ and 1641 .

${ }^{179}$ Munday, "A Second and Third Blast of Retreat," 70.

${ }^{180}$ Pollard, "Introduction," xiii.
} 
Apologists of the Elizabethan theatre responded to these attacks by citing the instructive function of the stage, and its ability to provide moral lessons for audience members. In his 1576 reply to Stephen Gosson's writings, Thomas Lodge wrote that plays have a pedagogical function, and that they can provide positive messages for audience members. Lodge argued that it was up to the spectator to recognize that what appears onstage is not meant to be interpreted literally, and must be deconstructed in order to have its moral lesson revealed. ${ }^{181}$ In his 1613 Apology for Actors, Thomas Heywood defended the practice of playing and imitation. He argued, much like Lodge, that the depiction of sin and vice onstage could be a positive and instructive experience for audiences. As well, he wrote that there were many characters who appear on stage whose behavior should be imitated and repeated, as they can provide models for correct living. ${ }^{182}$ The development of the theatre as a popular cultural and economic institution under Elizabethan attracted a significant amount of attention by critics who objected to the stage for various religious, moral and social reasons. These authors entered an essentially philosophical debate about the value of illusion and pretense, while also bringing light to the practical concerns that surrounded the act of playgoing. The debates between anti-theatricalists as well as apologists of the theatre continued throughout the seventeenth century until the closing of the theatres in 1642 .

${ }^{181}$ Thomas Lodge, “A Reply to Stephen Gosson's School of Abuse, in Defence of Poetry, Music and Stage Plays," in Shakespeare's Theater: A Sourcebook, ed. Tanya Pollard (Oxford: Blackwell Publishing, 2004) 38.

${ }^{182}$ Thomas Heywood, “An Apology for Actors,” in Shakespeare's Theater, 214. 


\subsection{The Content of Plays and Censorship}

Prior to the establishment of commercial theatre, most performances centered on spiritual themes and were performed by travelling actors at inns and large homes during festivals and religious holidays. After the Reformation, religious plays were widely discouraged by most Protestant authorities who saw playing as a tradition associated with Catholicism. At this time, drama increasingly began to explore themes of nationalism, monarchical authority, family life, and the struggles of the individual. Some themes however, such as those dealing with contemporary politics, religious controversies or national rivalries were forbidden from being represented onstage. However, these subjects continued to appear in drama as they were deeply imbedded in English society and politics. Religion was especially difficult to separate from theatre as it was inscribed in every detail of English life. Alexandra F. Johnston writes, "although religion was no longer the subject of theatrical presentation, public performances of all kinds continued to be tangled in religious issues." ${ }^{, 183}$ Nevertheless, authorities did make attempts to subject plays to censorship, though the enforcement of these laws remained sporadic and inconsistent for the most part. Indeed, legislation to govern the subject matter contained in plays was one of the first acts of the new Elizabethan regime.

In 1559 , a statute was enacted that required all plays be officially licensed. In 1569 , many cities prevented players from performing on Sundays and other religious holidays. The Master of the Revels, whose power was expanded during this period, was responsible for reviewing and editing all plays that were to be performed. In 1606, laws were passed to prevent actors from using oaths or saying anything blasphemous about God onstage. In 1610, the Master of the Revels was also given the power to license plays

${ }^{183}$ Johnson, "Tudor drama, theatre and society," 440. 
for printing. It was the duty of the Master of the Revels to ensure that particular individuals of authority, as well as certain nationalities, were not treated in a negative or profane way onstage. As well, he was to make sure that political and religious issues were not directly discussed within these works. Overall however, from 1578-1622, those men who served the position of Master of the Revels were relatively sympathetic to playing companies and granted licenses to almost all plays within this period. ${ }^{184}$ Ironically, censorship only created a heightened awareness of controversial topics, as audiences were now in a position to recognize subtle references and innuendo in plays. ${ }^{185}$ This was especially true of religious, political or sexual topics which were often disguised through word play or misrepresentation.

During the Elizabethan period, there was no consistent attitude towards the place of theatre in English society. The existence of censorship laws indicates that the state recognized the potential of the stage to criticize or invert traditional social and political mores. However, the continued existence of these theatres and the popularity of playgoing suggests that the stage was recognized as a semi-legitimate cultural and economic institution. Elizabeth herself was known to enjoy dramatic performances which remained popular at court. Louis Montrose argues that the state understood that theatre could be both entertaining and potentially useful as an instrument to express and reinforce the interests of the government. ${ }^{186}$ In fact, an acting troupe called "The Queen's Men" was created in 1583 by Francis Walsingham to serve the interests of the state. ${ }^{187}$ Though the state remained relatively tolerant of the theatre, city authorities seemed to dislike the

\footnotetext{
184 Pollard, "Introduction," xv.

${ }^{185}$ Shell, Shakespeare and Religion, 58.

${ }^{186}$ Louis Montrose, The Purpose of Playing: Shakespeare and the Cultural Politics of the Elizabethan theatre (Chicago: University of Chicago Press, 1996), 64.

${ }^{187}$ Johnson, "Tudor drama, theatre and society," 441.
} 
perceived social disruption caused by the existence of playhouses. Many of them viewed theatres as locations for idleness and feared the possibility of fomenting rebellion amidst large crowds. ${ }^{188}$ As a result, 'official' attitudes towards drama and the place of the stage remained contested and somewhat inconsistent within this period. The closure of the theatres in 1642 attests to the anxiety and continued concerns about representation that authorities felt at the end of the sixteenth century and through the middle of the seventeenth century.

188 Johnston, "Tudor drama, theatre and society," 440. 


\section{CHAPTER THREE: Performing Anti-clericalism in Doctor Faustus}

Anti-clericalism was a common feature of pre-Reformation English culture. Since the middle ages, writers often mocked the Catholic clergy and the figure of the Pope. ${ }^{189}$ The clergy was often associated with worldliness and materiality. They could be represented as jolly, overweight, sexually veracious and sometimes as uneducated and naive characters. ${ }^{190}$ The Reformation aggravated these representations, and anticlericalism became more common within literature of this period. ${ }^{191}$ In Doctor Faustus, Marlowe echoes these representations, and portrays the clergy as inept, foolish characters, while making a larger political statement about the papacy itself. Although these representations appear throughout both versions of the text, they are most clear in one particular scene of the play where Faustus and Mephistopheles encounter the pope at a papal banquet.

When Faustus first performs his conjuration in the first act, the audience is introduced to the character Mephistopheles, and Marlowe inserts an anti-Catholic joke through his representation of the character onstage. When Mephistopheles first appears to Faustus, he arrives in the form of a devil at which point Faustus instructs him to change his form into the shape of a man. Specifically, he states, "Go, and return an old Franciscan friar; / that holy shape becomes a devil best. ${ }^{, 192}$ There is little doubt that an

\footnotetext{
${ }^{189}$ Please see above.

190 James C. Bryant, Tudor Drama and Religious Controversy (Mason, GA.: Mercer, 1984) 125126.

${ }^{191}$ Christopher Haigh, "Anti-Clericalism and the English Reformation," History 68 (1983): 391407. Haigh argues that anti-Clericalism was a trend which followed the Reformation, and was not as popular before the Henrician reforms as some historians have asserted.

${ }^{192}$ Bevington and Rasmussen, "The A-text" in Doctor Faustus, 1.3:26-27. Hereafter, all references to Doctor Faustus come from Bevington and Ramussen editions. Citations from the A-text also appear in the B-text unless otherwise noted.
} 
anti-Catholic jab such as this would have registered with, and possibly evoked laughter from, Elizabethan audiences. It has been suggested in relation to both the A and B texts that the actor playing Mephistopheles would have indeed returned dressed as a friar within this scene. However, this is no indication within either text that this costume is ever removed until the third act when Mephistopheles, presumably still a man, takes on another form. If the actor who played Mephistopheles retained this costume throughout the first three acts of the play, then the comic effect of this joke would have remained throughout much of the production. Though only one of several small references to friars throughout the play, it is significant that one of the central villains of the story appears and remains in the form of a Catholic friar.

In act three, Faustus and Mephistopheles journey to Rome and disrupt a papal banquet. In the context of the entire play, the scene serves to illustrate how Faustus uses his magic and his powers to engage in childish activities instead of achieving the greatness that he so desired at the beginning of his adventure. More specifically, Marlowe uses this scene to mock several features of Catholicism, including members of the clergy and the pope in particular. The a-text and b-text versions of this scene contain significant differences in their style and subject matter. The b-text is much longer and features more characters than the a-text. It also has a more complex political message than the a-text which seems to have a more straightforward comical purpose. Nevertheless, both versions are riddled with anti-clerical and anti-papal statements which sixteenth century audiences would have recognized during performances. 
In the a-text, Mephistopheles tells Faustus that at the papal feast he should expect to see "...a troupe of bald-pate friars / whose summum bonum is in belly cheer." 193 The term 'summum bonum' traditionally refers to the infinite goodness of God, but is used by Marlowe to poke fun at the jovial and overweight friars. ${ }^{194}$ Both characters enter the papal chambers wearing an invisibility cloak, and watch as the Pope, the Cardinal of Lorraine and several friars enter and are seated. Faustus remarks "fall to, and the devil choke you an you spare," whispering to the Pope that the devil should choke him if he eats only sparingly, at which point Faustus snatches his food and drink away, eventually also hitting him in the ear. ${ }^{195}$ Several subsequent references are made to food and eating, with the Pope remarking at one point that his meat has been sent from the Cardinal of Florence, and that he drinks his wine in honour of his guests. The presence of a banquet table and the multiple references to food and wine might reinforce the characterization of the clergy as gluttonous individuals. Furthermore, the banquet scene itself may serve as a parody of the last supper where the Pope is represented as the anti-Christ and leader of a false church.

As Faustus grabs the food away from the pope and moves dishes about, the members of the banquet become afraid and the cardinal attributes these activities to a ghost, "newly crept out of purgatory, come to beg a pardon of your holiness." 196 This reference to the ability of the pope to pardon one's sins and limit one's time within purgatory may be a reference the selling of indulgences which were widely criticized during the Reformation. Furthermore, it could be mocking the notion of purgatory itself,

\footnotetext{
193 A-text, 3.1:52-53.

194 See footmote fifty-three in Bevington and Rasmussen, Doctor Faustus, 164.

195 A-text, 3:1:61. A Cardinal of Lorraine also appears in Marlowe's Massacre at Paris where he is implicated in a plot to murder French Protestants.

${ }^{196}$ A-text, 3:1:73-74.
} 
or the ability of the Pope to have an intercessory function in one's salvation. Having

become afraid of the disruption caused by the invisible Faustus, the Pope then calls on the friars to perform an exorcism to eliminate this nuisance. The friars enter with a bell, book and candle, chanting:

Cursed be he that stole his Holiness' meat from the table. Maledicat Dominus!

Cursed be he that struck his Holiness a blow on the face. Maledicat Dominus!

Cursed be he that struck Friar Sandelo a blow on the pate. Maledicat Dominus!

Cursed be he that disturbeth our holy dirige.

Maledicat Dominus!

Cursed be he that took away his Holiness' wine. Maledicat Dominus! ${ }^{197}$

It would have been difficult for audiences to take these maledictions seriously, as what is traditionally a very serious and dramatic ritual is used to alleviate the Pope's frustration at having lost his food. Furthermore, the repetition of the terms 'holiness' and "Maledicat Domnius" may have also contributed to the overall comic effect of this scene. According to the stage directions, Faustus and Mephistopheles beat the friars during this ritual, fling

${ }^{197}$ A-text, 3:1:90-95. The Pope initially asks the friars to "lay a dirge" to eliminate the "ghosts" interrupting his banquet. The Dirige, which came from the Office of the Dead, was removed from Protestant worship and the Book of Common Prayer. As a result, the very idea of an intercessory prayer for the dead may mocked here as an element of traditional Catholic worship. Furthermore, instead of chanting the dirige, the friars instead conduct a ritual which blends elements of excommunication and exorcism. Excommunication was traditionally done by tolling a bell, closing a book (the bible) and extinguishing a candle. The phrase "Maledicat Dominus," which translates as "may the lord curse him," also comes from the traditional ceremony of excommunication. However, the behavior of the friars suggests that it is not an excommunication that they are attempting, but an exorcism. Bevington argues that both of these ceremonies are confused in the play and the Damnable Life sourcebook. As a result, there are several interpretive possibilities as to what Marlowe is representing here. One possibility is that Marlowe purposely blends all three rituals to generally mock the use of these ceremonies in any worship. Specifically, he could be mocking the Friars who themselves are not able to distinguish between these rituals and instead use a compilation of them all. The reference to excommunication may have resonated with those audience members who were aware of the Pope's excommunication of Elizabeth in 1570. Another interpretive possibility is that the ritual of exorcism itself is mocked and proven ineffectual through the friar's failure to drive Faustus and Mephistopheles away. It seems that Marlowe is playful here in how he mixes these rituals together. In the Globe performance, the friars also use holy water in their ritual which removes this ambiguity and makes the ritual a straightforward exorcism. See Bevington, Doctor Faustus, 164-167. 
fireworks at them, and run away. This seems to suggest that Faustus and Mephistopheles do not believe that their ritual has much power, as they continue to heckle them before they make their escape. The failure of the exorcism to effectively drive away Faustus and Mephistopheles attests to the futility of this Catholic ritual. ${ }^{198}$ The comic language of this scene suggests that Faustus' actions were not meant to provoke indignation from audiences at his disrespect for the Pope and the friars. Instead, it was meant to be funny and Marlowe was aware that contemporary audiences would have found this scene to be amusing.

Like the a-text, the b-text also begins with Mephistopheles' desire to wreak havoc at the papal banquet. He tells Faustus that he will help him "To make his monks and abbots stand like apes...To beat the beads about the friars pates / Or clap huge horns upon the cardinals heads." ${ }^{\prime 199}$ Within the a-text, Faustus participates in most of the action while Mephistopheles presumably watches. Here, both characters are involved in the disruption of the banquet, and Mephistopheles' speech seems to indicate a particular desire to humiliate the members of the clergy. At this point, the Pope, named Adrian, enters the chamber alongside the Cardinals of France and Padua, the Bishops of Lorraine and Rheims, King Raymond of Hungary, a rival German Pope named Bruno, as well as several monks and friars. In this scene, which is loosely based on Foxe's Acts and Monuments, Pope Adrian humiliates the rival Pope Bruno who was elected by the Holy Roman Emperor. This scene was based on Foxe's account of a confrontation between the twelfth century Pope Alexander and his rival Pope Victor IV, who was elected by

\footnotetext{
198 The powerlessness of these rituals is explored further within chapter four.

${ }^{199}$ B-text, 3:1:82-85.
} 
Emperor Frederick Barbarossa. ${ }^{200}$ In Foxe's account, Alexander forces the emperor

Frederick to kneel before him, so that he may place his feet on his neck. This also appears within Marlowe's text when Pope Adrian demands that Bruno kneel before him,

To me and Peter shalt thou grovelling lie

And crouch before the papal dignity.

Sound trumpets, then, for thus Saint Peter's heir

From Bruno's back ascents Saint Peter's chair. ${ }^{201}$

The Pope then sends away the Cardinals of France and Padua to find out what a religious council has decided to do with Bruno. Seeing Bruno's humiliation, Faustus decides to "Restore this Bruno to his liberty / And bear him to the states of Germany." ${ }^{, 202} \mathrm{He}$ and Mephistopheles magically take the forms of the two cardinals, return to the Pope, and tell him that the council has decreed that Bruno and the Emperor be burned as heretics. They then drag Bruno away and lead him to safety.

This is the second time within the b-text that a religious costume has been used for a profane, comedic purpose. As easily as Mephistopheles was first able to appear in the form of a friar, he and Faustus are now able to dress as Cardinals. ${ }^{203}$ Given that such vestments were sacred in the Catholic Church, the ability of Faustus and Mephistopheles to easily put them on and off undermines their spiritual function. It suggests that any

${ }^{200}$ The B-text scene between the rival popes does not appear in the German Faustbook. In 1945, Lieslie Oliver first argued that these additions, added by Rowley, seem to be taken from John Foxe's Acts and Monuments. Rowley had used Foxe's work previously within his own play When You See Me You Know Me, published in 1605. Within Foxe's story, it is the emperor and not Bruno who is forced to kneel at the pope's feet, but much of the language and the contempt for the pope's power is borrowed from Foxe's text. In both stories, Bruno expresses to the Pope that he submits only to Peter and not to him, to which the Pope replies "Et mihi et Petro," in Foxe, and "To me and Peter shalt thou grovelling lie," in Marlowe. See footnote 88 in Bevington and Ramussen, Doctor Faustus, 236.

201 B-text, 3:1:94-97. Pope 'Adrian' may refer to Hadrian VI, who was Pope during the events of the play, or to Hadrian IV who also had tensions with the emperor. The name Bruno seems to be arbitrary and does not refer to any historical individual. Philip Brockbank, Marlowe: Doctor Faustus (Woodbury, NY: Barron's, 1962), 49.

${ }^{202}$ B-text, 3:1:120-121.

${ }^{203}$ It is unclear here if Mephistopheles puts the Cardinal's costume on top of his friar costume, or if he removes the friar costume completely and returns in later scenes wearing something new. 
individual, even a devil in the case of Mephistopheles, can put on these garments and appear to be holy. The implication is that these garments are just another form of dress and can be used to conceal something which is not sacred. As a result, Faustus and Mephistopheles are able to do symbolic violence to the religious vestments and clothing traditionally worn by Catholic clergymen. ${ }^{204}$

Having becoming invisible, Faustus and Mephistopheles then arrive at the papal banquet and disrupt the guests from eating. In addition to snatching away the Pope's meat and wine as in the a-text, Faustus hits the pope on the head, causing him to flee before the friars enter to perform their exorcism. There is much more dialogue in the b-text version of this episode than within the a-text. This additional dialogue provides a more decidedly Protestant nationalist reading of this scene which one does not get from the a-text. For example, the conflict between the Popes Adrian and Bruno which is entirely missing from the a-text raises several issues of national authority and Protestantism which came into being during the Reformation.

While describing his anger at Bruno for his unlawful election as pope by the German emperor, Pope Adrian expounds the authority of his office and his annoyance at those who assert their power over him. Of the emperor he remarks, "He grows too proud in his authority, / Lifting his lofty head above the clouds, / And like a steeple overpeers the Church. ${ }^{205}$ He vows to limit his authority and cites past examples where the Pope has dealt with secular rulers who try to assert themselves in this manner;

${ }^{204}$ Specifically, Faustus and Mephistopheles do symbolic violence to the position of the Cardinal which was no longer a clerical office in England and was therefore ripe for criticism. The concept of "symbolic aggression" in theatre is borrowed from Stephen Greenblatt, Shakespearean Negotiations: The Circulation of Social Energy in Renaissance England (Oxford: Clarendon Press, 1990), 113.

${ }^{205}$ B-text, 3:1:132-134. 
That Peter's heirs should tread on emperors And walk upon the dreadful adder's back, ...So will we quell that haughty schismatic And by authority apostolical Depose him from his regal government ${ }^{206}$

Furthermore, he states that Papacy has "all power on earth bestowed on us," he therefore "cannot err" and may do "whatso pleaseth us." He concludes his speech about power by stating that "He [the emperor] and thou and all the world shall stoop, / Or be assured of our dreadful curse/To light as heavy as the pains of hell.,"207

In this scene, the Pope is characterized as being incredibly self-important and obsessed with his own power. His speech indicates a desire to punish any secular ruler that would attempt to rival this authority. This conflict over power would have seemed familiar to contemporary audiences, as these same issues were reminiscent of the struggles between Henry VIII and Pope Clement VII in the 1530s which led to the break with Rome. In his writings, Luther often expressed that the Pope should have no authority over secular rulers. This idea clearly appealed to Henry VIII and was a common feature of the English Reformation. ${ }^{208}$ The Henrician Act in Restraint of Appeals as well as the various acts of Royal Supremacy asserted the King's prerogative and legitimized his control of all matters religious and spiritual within England. Much of the Henrician Reformation had dealt with issues of what Christopher Haigh terms "national sovereignty and monarchical supremacy."209 Elizabethan audiences may well have sympathized with the character of the nominee of the emperor who could be seen as victim to the Pope's

${ }^{206}$ B-text, 3.1.139-145.

${ }^{207}$ B-text, 3:1:150-160.

${ }^{208}$ Clifford Davidson, "Doctor Faustus at Rome," Studies in English Literature, 1500-1900 9:2 (1969), 236.

${ }^{209}$ Christopher Haigh, English Reformations: Religion, Politics and Society Under the Tudors (New York: Oxford University Press, 1993), 121. 
overreaching hand. Furthermore, when the Pope within this scene threatens that "Both he [the emperor] and thou shalt stand excommunicate," audiences may have been reminded of Pope Pius V's excommunication of Elizabeth in 1570. As a result, English audiences may have sympathized with Pope Bruno as he is representative of the Emperor's right to appoint his own religious leader. ${ }^{210}$ In England, Bruno's parallel would be the Archbishop of Canterbury. ${ }^{211}$

In addition to being haughty and arrogant, the Pope within the b-text is portrayed as a cruel and unforgiving individual. In the banquet scene, Faustus and Mephistopheles temporarily disappear just as the two real Cardinals re-enter the Papal chambers.

Completely unaware of the events that took place after Mephistopheles magically put them to sleep, the cardinals tell the Pope in confusion that no council decreed that the Emperor and Bruno be executed to which the Pope replies, "By Peter, you shall die...Hale them to prison. Let their limbs with gybes!" at which point two attendants drag the cardinals away. ${ }^{212}$ This hasty act does not make the Pope seem very patient or merciful. ${ }^{213}$ As nonchalantly as he was able to deal with the council's decree to execute the emperor and Bruno, he is able to dismiss the cardinals and send them to their deaths. Not only does the Pope seem gullible for believing the false cardinals in the first place, but he now seems cruel in his swift and unforgiving action. ${ }^{214}$ When Faustus and

\footnotetext{
${ }^{210}$ On the other hand, audiences may have seen Bruno as equally bad as the Pope, as he is also laying claim to this office which Protestants deemed illegitimate.

${ }^{211}$ Ibid., 237.

${ }^{212}$ B-text, 3:2:51-52.

${ }^{213}$ As Kesselring notes in her work, mercy was often regarded in the early modern period as an essential quality for any prince or ruler to possess. In fact, granting clemency was often used to consolidate and to 'perform' royal authority. See Krista Kesselring, Mercy and Authority in the Tudor State (Cambridge: Cambridge University Press, 2003).

${ }^{214}$ David Bevington, "Staging the A and B texts of Doctor Faustus," in Marlowe's Empery: Expanding his critical Contexts, eds. Sara Munson Deats and Robert A. Logan (Newark: University of Delaware Press, 2002), 51.
} 
Mephistopheles subsequently disrupt his meal, the audience may have felt that the Pope was getting what he deserved for being such a proud and unmerciful individual. In the context of the conflict between the Pope and Bruno, Faustus' harassment of the Pope in the b-text banquet scene may have seemed more justified to audiences than within the atext.

Through his desire to mock the Pope and help the Emperor and Bruno, Faustus becomes a heroic figure within this scene. While dressed as the cardinal, Faustus refers to the Pope's rivals as “... Lollards and bold schismatics.",215 Several lines later, the Pope echoes this line shortly after, referring to Bruno and the emperor as "loathed Lollards and base schismatics. ${ }^{.216}$ In post-Reformation England, Lollards were regarded as early martyrs for the Protestant cause. This reference may have reinforced the audience's sympathy with these characters and their admiration for Faustus in leading Bruno to safety. Faustus' 'good deed' would only reinforce the increasingly negative portrayal of the Pope. One could argue that by helping these figures, Faustus is displaying the characteristics of a "Protestant hero" during this scene. ${ }^{217}$

The reference to Lollardy is not the only time in the play that Faustus alludes to English Protestantism. When Faustus discusses what he could do with infinite power within the first scene of the a-text, he mentions that he wishes to "chase the Prince of Parma from our land."218 The Spanish Prince of Parma was the governor general of the Netherlands from 1579-1592. He was the commander of the Spanish troops during the

${ }^{215}$ B-text, 3.1:176.

${ }^{216} \mathrm{~B}$-text, 3.2.42.

${ }^{217}$ In the context of the entire play however, his position is slightly more controversial. Ironically, much of the language Faustus uses to describe his lust for power within the first act is echoed by Pope Adrian within this scene.

${ }^{218}$ A-text, 1:1:85. 
Armada and was viewed by English Protestants as a Catholic oppressor. David Bevington writes that the Prince represented "the model of the foreign tyrant whom Protestant patriots would wish to drive out." ${ }^{, 219}$ Other references to the Spanish appear at the beginning of the play. Faustus discusses his curiosity for magic and the power and wealth he hopes to attain from it. His friend Valdes provides encouragement, telling Faustus that "As Indian Moors obey their Spanish lords, / So shall the spirits of every element / Be always serviceable to us three." Furthermore, he compares the riches that Faustus could obtain to the wealth acquired from the Spanish colonial project: "...from America the golden fleece, / That yearly stuffed old Philip's treasury."220 These references to Spaniards as colonizers may be allusions to the "Black Legend" of this period which demonized conquistadors and represented the Spanish as evil as a result of their treatment of South American populations. ${ }^{221}$ The Spanish remained one of England's most threatening Catholic enemies during Elizabeth's reign. These references to the Spanish may have reinforced these negative sentiments and strengthened England's self-image as a Protestant nation. Marlowe's allusions to Papal conflict, Lollardy and the Spanish are indicative of how he uses the language of sixteenth century Protestantism within his work. Furthermore, one could argue that the a-text, through its representation of the conflict between the rival Popes, has a more politically anti-papal message than does the a-text. $^{222}$ Therefore, Faustus' adventure in Rome seems to have greater symbolic importance in the b-text version of the play.

${ }^{219}$ See footnote 95 in Bevington and Ramussen, Doctor Faustus, 117.

${ }^{220}$ B-text, 1.2.115; 125-127.

${ }^{221}$ William S. Maltby, The Black Legend in England: The Development of anti-Spanish Sentiment in England 1558-1660 (Durham: Duke University Press, 1971).

${ }^{222}$ Thomas Healy, "Doctor Faustus," in The Cambridge Companion to Christopher Marlowe, ed. Patrick Cheney (New York: Cambridge University Press, 2004) 185. 


\subsection{The B-text of Doctor Faustus in Performance}

There are several instances of anti-clericalism and Protestant nationalism which come through in a textual analysis of Doctor Faustus. A dramaturgical analysis may shed light on the performance possibilities of Marlowe's work and how nuanced changes in production may have altered the meanings that were created on playhouse stages. Within its 2011 performance season, the Shakespeare's Globe Theatre in London had a running production of Doctor Faustus which offers a unique opportunity to study how the staging of this play mediates negative representations of Catholicism that appear in the text. ${ }^{223}$ The two Globe performances discussed emphasized the negative portrayal of the Pope which is visible within the b-text of the play. In the Globe performance, when the Pope first enters his chambers, he is accompanied by a large entourage consisting of the guests who will later attend his banquet as well as several guards and priests who carry staffs and bells and sing softly. Dressed in the traditional papal vestments, there is a great deal of ceremony surrounding his entrance as he makes his way onto the center of the stage carrying a staff. ${ }^{224}$ The Pope and his group enter the theatre through the vomitorium, walking through the audience and up several steps to center stage. This creates a sense of intimacy with the audience who have to part in order to let the actors walk through, thus becoming participants in this heavily ritualized entrance. After making his way center stage, the Pope is seated on a throne, which serves as a symbolic representation of his

${ }^{223}$ The performances I use for this analysis took place on August 13,2011 at 7:30 pm, as well as August 14,2011 at 1:00 pm at Shakespeare's Globe Theatre in London, England. References to the Doctor Faustus are the same within both performances unless otherwise noted.

${ }^{224}$ This dramatic entrance was likely based on the stage directions which indicate "Enter the Cardinals and Bishops, some bearing crosiers, some the pillars; Monks and Friars singing their procession. Then the Pope and Raymond, King of Hungary, with Bruno led in chains. B-text, 3:1. 
power, while his other attendants stand around him. This period production of Doctor Faustus contains few props and objects on-stage. In context of this overall simplicity and relative bareness of the stage, the excess surrounding the Pope's entrance is significant, as it is one of the few instances where audiences get to see this type of spectacle and show. The visual opulence on-stage could symbolize several different things within this scene. Firstly, the use of these objects could emphasize the worldliness and wealth of the papacy which was heavily criticized within the early modern period, especially during the Protestant Reformation. Therefore, these objects may symbolize the superficiality of the Pope's power which is based on materiality and ceremony rather than any real sacred connection to God. On the other hand, for those audience members who still recognized these objects as spiritually valuable, the cruel behaviour of the Pope towards Bruno would contrast sharply with the religiosity surrounding him. Therefore, the Pope would seem empty by comparison. In either case, the Pope remains a negative figure and it is reasonable to argue that Elizabethan audiences would have recognized his deliberate characterization as such in this scene.

When the Pope first enters this scene, there exist numerous possibilities for staging that can create degrees of either sympathy or animosity for his character. If the Pope was portrayed by an older actor who slowly made his way onstage without ceremony, he could be interpreted as a humble, wise figure whose speech and authority should be carefully listened to and respected. On the other hand, if the Pope was a younger figure who confidently entered the scene and whose aesthetics matched the visual excess onstage, audiences could interpret him as being vain, superficial and not to be taken too seriously. In the Globe production, the Pope was played by an older actor, 
and the lines were spoken with a light, wavery voice. The only other elderly figure within the play, the 'Old Man' who appears in the final act encouraging Faustus to repent, is portrayed in sharp contrast to the character of the Pope. The 'Old Man' also speaks with a light voice, but he is dressed in plain grey clothes and offers Faustus peace through redemption. When he appears onstage, he also enters through the same vomitorium the Pope used, though he shuffles onstage quietly and is unaccompanied by an entourage. By comparison, the Old Man is the wiser figure of the two since, unlike the Pope, he offers salvation. Within the Globe production, the actor who portrayed Pope Adrian also played Lucifer, and audience members may unconsciously make the association between the two characters. ${ }^{225}$ Actors commonly play multiple roles in theatre, and this opens up the possibility for unintentional associations between two parts. It is significant because in this instance, this association may strengthen the characterization of the Pope as a negative figure, and particularly represent him as the literal anti-Christ.

The stage directions within this scene of the b-text indicate that when Bruno enters, he is "'led onstage in chains." ${ }^{, 226}$ In the Globe production, Bruno is dramatically dragged through the audience onto the stage by two of the Pope's guards. He is barely clothed, and wears only a white loin cloth. Bruno is bound by chains and is also covered in blood and bruises within this scene. His character has a beard and long brown hair, resembling Christ. Whether or not this is intentional, it certainly creates a great deal of sympathy for Bruno's character and that much more derision for the Pope. One of the Pope's guards also carries in Bruno's triple crown which too is bloody, and sets it on the

${ }^{225}$ However, it is not explicitly clear onstage through their costuming that one actor plays both roles. Those audience members who had examined the program of the performance would have had access to this information.

${ }^{226}$ B-text, 3:1. 
edge of the stage. The blood may suggest here that the power of the papacy is acquired and sustained through violence. When the Pope begins to speak about his authority and about Bruno's wrongful appointment by the emperor, he stands at the back center of the stage, and Bruno is on his knees in front of him, positioned literally and figuratively between the Pope and the triple crown. As a result of this staging, the Pope is represented as a character whose ultimate goal is to secure his power, an image only reinforced through the lines he speaks within the text. The Pope's physical position makes him the dominant figure, and almost cruel and overbearing as he hovers over crouching Bruno.

After Bruno forcefully speaks his lines to defend himself, one of the Pope's guards cuts out Bruno's tongue in the Globe performance which causes the audience to gasp. This particular action does not appear in the stage directions of either printed version of the play, and demonstrates the dramatic possibilities and choices available in the dramaturgy of Doctor Faustus. This gesture greatly contributed to the cruel representation of the Pope who signalled his guard to perform this act in the first place. When the Pope speaks of the authority of his office and the power that is ascribed to one in his position, he seems to disavow personal responsibility for his actions, and justify them by referring to the obligations of his position. His claims of infallibility in the face of his cruel behaviour only contributes to the negative representation of his character within this scene. The continued presence of his large entourage onstage, as well as the throne which remains in the background, seem to suggest that the Pope's priorities remain the quest and solidification of power.

As he gets his tongue cut out, Bruno is kneeling on the thrust of the stage with his back to the audience facing both the Pope as well as one of his guards. Bruno's position 
on the thrust of the stage, around which spectators gather, makes it appear as if he is a member of the audience who is facing the Pope in the same direction as everyone else. The dismembered tongue is then thrown directly into the crowd further implicating the audience in this act who are forced to directly confront the Pope's violence. Bruno's positioning onstage may have reinforced audience sympathy with his character, as the spectators have now become direct witnesses to the cruelty onstage. In this scene, the Pope's entrance through the audience, as well as the spectacle created when the tongue is thrown into the crowd creates an intimate relationship between the audience and the actors. This intimacy may have contributed to a greater emotional involvement with the violence onstage and strengthened sympathy with Bruno. As a result, the Globe performances of Doctor Faustus seem to reinforce the negative representation of the Pope demonstrated in the text. The overall treatment of the Pope in Doctor Faustus contributes to a dialogue of anti-clericalism and English Protestant nationalism which Marlowe continues within other plays he composed in the 1590s.

\subsection{Anti-Clericalism and Protestant Nationalism in the Jew of Malta and the Massacre at Paris}

The tropes of anti-clericalism and Protestant nationalism that are evident in Doctor Faustus also appear in Marlowe's other works, the Jew of Malta and the Massacre at Paris. In the Jew of Malta, anti-clericalism functions to discredit the clergy as intelligent and spiritual individuals. In the Massacre at Paris, Marlowe talks about English Protestantism in the context of the St. Bartholomew's Day Massacre and references contemporary English fears about a domestic Catholic rebellion. The anti-Catholicism evident within both plays illustrates the various representative possibilities of this religion 
in the Elizabethan theatre. It also demonstrates how Catholic religious leaders continued to be portrayed as spiritually empty figures to be laughed at while simultaneously posing a threat to the Protestant nation.

In his 1592 play, The Jew of Malta, one can see numerous examples of Marlowe's exploration of anti-clericalism. ${ }^{227}$ A story about greed, revenge, hypocrisy and xenophobia, the Jew of Malta is a heavily ironic play which parodies several religious institutions and beliefs. The protagonist is a wealthy Jew named Barabas who is forced to turn over his money and property to the Christian rulers of Malta as tribute to the Ottoman Turks. His former home is transformed into a convent and Barabas hatches a plan to have his daughter take religious vows there so that she might retrieve treasure that he had hidden within. Abigail's place within this convent and her interaction with its inhabitants provides numerous opportunities for a comical representation of Catholic friars and nuns. In the Jew of Malta, the clergy are represented as sexually and financially self-indulgent, as well as childish and gullible characters.

Marlowe's treatment of nuns within the Jew of Malta reflects a common pattern which appeared in early modern literature. The figure of the nun in the early modern period represented both the absurdity of female authority and separatism, as well as the “inevitable eruption of repression into licence" of institutionalized religious individuals. ${ }^{228}$ As a result, nuns were the part of Catholicism that was supposed to be

${ }^{227} 1592$ refers to the first recorded date of performance. The play itself was not printed until 1633. John Parker, "Barabas and Charles I," in Placing the Plays of Christopher Marlowe, eds. Sara Munson Deats and Robert A. Logan (Aldershot: Ashgate, 2008), 167-184. Henslowe's Diary records thirty-six performances given by various companies at the Rose theatre between February 1592 and June 1596. By the early seventeenth century, the play was also performed by Queen Henrietta's Company who played at the Cockpit or Phoenix theatres. It was performed throughout Germany in the seventeenth century and then had an English revival in April 1818. N. W. Bawcutt, ed. The Jew of Malta (Manchester: Manchester University Press, 1978), 1-4.

${ }^{228}$ Francis E. Dolan, “Why are Nuns Funny?” Huntington Library Quarterly 70:4 (2007) 509. 
dismissed instead of feared. ${ }^{229}$ This representation grew out of contemporary perceptions of both females and Catholics. Nuns, much like Catholics, were thought to be obedient individuals who were unable to think for themselves. In many ways, Abigail, as a pawn of her father's plans for greed and revenge, conforms to this representation. Early seventeenth century texts such as Thomas Robinson's The Anatomy of the English Nunnery at Lisbon in Portugall presents nuns as stupid, superstitious and easily led which can stand as a wider representation of Catholics everywhere. ${ }^{230}$

Nuns, as well as other members of the clergy, were also represented as sexually licentious individuals. The fact that they were institutionalized within a convent and cut off from the rest of society only contributed to the sense of mystery and distrust about what behaviours occurred behind cloistered walls. ${ }^{231}$ Abigail's first interaction with the abbess of the convent, as well as the friars Bernadine and Jacamo, contains one of the earliest sexual references of the play. As Abigail explain her reasons for becoming a novice, Bernadine makes a quip to Jacamo of how Abigail invokes "a moving spirit," demonstrating his arousal at her presence. ${ }^{232}$ An accompanying gesture in any performance of this play may have contributed to the portrayal of these friars as sexually deviant individuals. In the following scene, upon hearing of her conversion, a young man named Mathias also comments on her appearance, remarking that "better would she far become a bed, / Embraced in a friendly lover's arms, / than rise at midnight to solemn

${ }^{229}$ Ibid., 509-510.

${ }^{230}$ Ibid., 509-512

${ }^{231}$ Dolan, Whores of Babylon, 85-94. Kate Chedgzoy, "'For Virgin Buildings Oft Brought Forth': Fantasies of Convent Sexuality," in Rebecca D'Monté and Nicole Pohl, eds., Female Communities, 1600 1800: Literary Visions and Cultural Realities (New York: St. Martin's Press, 2000), 53-75.

${ }^{232}$ Christopher Marlowe, The Jew of Malta, ed. Richard W. Van Fossen (Lincoln: University of Nebraska Press, 1964) 1:2:300. 
mass." 233 There are several instances within the play where nuns, especially Abigail, are sexualized in this way. At one point, a friend of her fathers' explicitly asks Abigail, "have not the nuns fine sport with the friars now and then?"234 When Abigail eventually commits suicide after hearing of her lover's death, Friar Bernadine states, “ay, and a virgin, too, that grieves me most." ${ }^{, 235}$ Associating the clergy with sexual licence does not necessary send a specifically anti-Catholic message to audiences, as these representations existed long before the Protestant Reformations in England and undoubtedly could apply to the Anglican clergy as well. However, through these representations, Marlowe does create comedy at the expense of the Catholic clergy. They are portrayed as individuals who are hypocrites for engaging in sexual acts while swearing vows of chastity and abstinence. In a post-Reformation environment, these types of representations would have had a particular symbolic importance and social function to further alienate English Catholics.

In addition to their alleged sexual licentiousness, Marlowe represents the clergy as greedy and self-indulgent. This is most clear in a scene where Barabas falsely professes that he plans join a monastery and donate his recently earned wealth to its inhabitants. Upon hearing this, Friars Bernadine and Jacamo get into a childish argument with one another while trying to convince Barabas to join their respective orders. At one point during their argument, Jacamo states that Barabas should avoid Bernadine's order just because "they wear no shirts, and they go barefoot.",236 The stage directions indicate that the argument becomes physical and two friars begin to fight. Though the directions do

$2331: 3: 6-9$.

234 3:3:35-36. Matthias' comment that Abigail, an attractive female, should not waste her life away in a convent is a theme that Shakespeare would pick up on within his play Twelfih Night.

235 3:6:42.

236 4:1:87. 
not indicate in which manner these two characters fight, it is reasonable to assume from the dialogue that it is juvenile and comical. The two clergymen within this scene seem very infantile, fighting one another over the prospect of wealth. They do not seem concerned with spiritual matters or any desire to help Barabas is his, albeit insincere, desire for penitence. Their fighting seems to represent their lack of faith in the face of a bribe. ${ }^{237}$ These clergymen are concerned with wealth and materiality. Representations of the clergy as greedy often came through in such Protestant writings as Simon Fish's 1529 pamphlet, the Supplication for Beggars which criticized the clergy for having a disproportionate share of England's wealth, as well as John Bale's 1546 The Acts of English Votaries, which generally critiqued the entire monastic system in England. ${ }^{238}$ In addition to portraying the clergy as greedy, the behaviour of the friars during their argument is indicative of another way in which Marlowe represents Catholicism in the Jew of Malta: childish and unintelligent. The unintelligence of these clergymen comes through in their gullibility in believing Barabas' desire to convert to Catholicism and their childishness is visible in their fighting. Just as these friars fell for Barabas' false repentance, they easily believed Abigail's false religious profession earlier within the play. Within the Jew of Malta, the Catholic clergy are represented as absurd, gullible and foolish individuals. Marlowe fashions them as characters to be laughed at; they are not at all to be taken seriously. Through this comedy, Marlowe undermines their function as spiritual leaders which could help to further alienate Catholicism in post-Reformation English society.

${ }^{237}$ Stevie Simkin, Marlowe: The Plays (Houndmills, Basingstoke, Hampshire: Palgrave, 2001) 90.

${ }^{238}$ Both writings were central to the anti-Clerical discourse in early modern England. For a discussion of their significance, see Donna B. Hamilton, "Religion" in A Concise Companion to English Renaissance Literature, ed. Donna B. Hamilton (Malden, MA: Blackwell, 2006), 32-53. 
In contrast to the representation of Catholicism within the Jew of Malta as a religion to be laughed at, Marlowe's Massacre at Paris depicts Catholicism as a national and political threat to be taken seriously. The last of Marlowe's known plays, the Massacre at Paris was written around 1592 and has often been dismissed by critical scholarship due to the incomplete state of the existing text ${ }^{239}$ Based on the St. Bartholomew's Day Massacre of 1570, the play is known for its graphic violence which seems to both condemn and parody religious politics and extremism. ${ }^{240}$ The Massacre deals with the tensions between French Catholics and Protestant Huguenots during the sixteenth century. Though set in France, Elizabethan audiences would have understood the conflicts within the play which deal with contemporary foreign politics and raise important questions about state religion, political loyalism and individual conscience, all of which were important issues within England during this time. ${ }^{241}$ The central villain within the play is the ambitious Catholic Duke of Guise who plots the massacre to rid France of Protestantism. Through this character, Marlowe was able to exploit contemporary fears of a similar Catholic conspiracy occurring in England.

${ }^{239}$ The exact date of composition remains unclear. Historians have estimated that it was composed after the death of Henry III in August of 1589 and sometime before its first performance in January of 1593. The earliest existing full text of the Massacre is an undated octavo which was is a memorial reconstruction produced by one or more actors familiar with the play. The existing text of the Massacre is abridged and only about 1250 lines long. As well, several lines are repeated within the text and many of the characters remain underdeveloped. In 1983, Julia Briggs criticized the undeveloped state of scholarship on the Massacre while bringing attention to the complex discussion of politics, sexuality, violence and religion that comes through within the text. Julia Briggs, "Marlowe's Massacre at Paris: A Reconsideration," Review of English Studies 34 (1983) www.jstor.org/stable/517240 (accessed January 14, 2011), 257-277.

${ }^{240}$ The play has often been dismissed as crude, Protestant propaganda by such scholars as H.S. Bennet but this notion has been challenged by Julia Briggs, Judith Weil and Sara Munson Deats.

${ }_{241}$ Briggs, "Marlowe's Massacre at Paris," 259. Marlowe's play is a dramatized version of the St. Bartholomew's Day Massacre and therefore it is not a historically accurate reconstruction of this event. Marlowe based his work on a number of contemporary writings about the Massacre including the Huguenot lawyer Francois Hotman's $1573 \mathrm{~A}$ true and plaine report of the Furious outrages of Fraunce and Simon Goulart's 1576 edited compilation Memoires de l'etat de France sous Charles neuvieme. Marlowe spent time in France in 1587, and it is likely that he encountered hearsay and used oral sources within his play. Paul Kocher has argued that Marlowe's sources for this play were Protestant-biased. However, Julia Briggs pointed out that Marlowe may have also used pamphlets that were sympathetic to the Catholic League cause. 
The Massacre at Paris is the most explicitly anti-Catholic play of all of Marlowe's works. ${ }^{242}$ Structured into twenty four short scenes, the play is known for its violent depiction of the murder of French Protestants. Within the play, Marlowe's makes significant use of violent language to add to the general theme of religious hatred. ${ }^{243} \mathrm{He}$ consistently repeats terms such as 'murder', 'deadly', 'kill', 'stab', 'massacre', 'hell' and 'bloody,' which may have had a significant impact on contemporary audiences. The play is very action-oriented and there is a lot of quick movement on stage, especially during the murder scenes. Though it also deals with themes of personal ambition and dynastic rivalry, the central action of the play is concerned with the massacre itself and the hatred the Duke of Guise expresses towards Protestants within the play, constantly referring to them as 'upstart heretics' within the text. ${ }^{244}$ On several occasions, the Duke references the Papacy and Phillip II of Spain as providing him with the financial and military support he needs to carry out violence towards Protestants. ${ }^{245}$

Though much more explicit, the Massacre at Paris does share at least one important reference with Doctor Faustus in its treatment of Protestant nationalism. The Spanish Duke of Parma, alluded to in Faustus as a hated enemy of the English, is also referenced within the Massacre. In the twenty-first scene of the play, when the Duke of

${ }^{242}$ English sentiment towards the historical massacre itself remained mixed within this period. However, a study of literature published in England about the massacre seems to indicate some English sympathy for French Protestants as anti-Guise sentiment was high in this period. Elizabeth I herself dressed in mourning clothes in the days after the massacre occurred. A.G. Dickens, "The Elizabethans and St. Bartholomew," in The Massacre of St. Bartholomew: Reappraisals and Documents, ed. Alfred Soman (The Hague: Nijoff, 1974),52-70.

${ }^{243}$ Probes, "Rhetorical Strategies for a 'locus terribilis': Sense, Signs, Symbol and Theological Allusion in Marlowe's Massacre at Paris," 153-155.

${ }^{244}$ Christopher Marlowe, "The Massacre at Paris," in The Complete Works of Christopher Marlowe Vol. 5, ed., Roma Gill (Oxford: Clarendon Press, 1987) 4:20.

245 "For this, from Spain the stately Catholics/Sends Indian gold to coin me French ecues;/For this, have I a largess from the Pope,/A pension and a dispension too." 2:60-64. 
Guise is murdered for his villainy, he cries out "Philip and Parma, I am slain for you."246 His association with Parma, and with Philip the King of Spain in general may have struck Elizabethan Protestants within the audience who feared a Catholic rebellion, aided by foreign powers, occurring in England. After seeing his dead body, King Henry recounts the treachery of Guise and lists his crimes which include "...cause the King of Spaines huge fleete / to threaten England and to menace me."247 This reference to the Spanish Armada would not have gone unnoticed by audience members. Furthermore, the King references how the Duke drew "a sorte of English priestes, / From Doway to the Seminary at Remes, / To hatch forth treason gainst their naturall queene."248 This reference to seminary priests and their alleged conspiracies against Elizabeth are directly related to characterizations of Jesuits within this period. At the end of the play when the King is betrayed and murdered, he cries out,

...I here do sweare, To ruinate that wicked Church of Rome, That hatchet up such bloudy practises. And here protest eternall love to thee, And to the Queene of England specially, Whom God hath blest for hating Papistry. ${ }^{249}$

If these lines were spoken with force and directed towards the audience, their impact would have been incredibly significant. This speech by Henry could have aroused a sense of national Protestantism amongst some audience members, and contributed to a sense of imminent danger.

Though significantly less subtle than Doctor Faustus, the Massacre at Paris arouses English national sentiment and makes the elimination of Catholic threat seem a

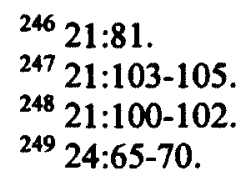


state priority. Marlowe deliberately references England throughout the text to draw attention to religious conflict present within both countries at this time. French Protestants within the text are constantly referred to as 'Puritans' which may have helped strengthen the association between the Massacre in France and its potential of occurring within England. Anti-Jesuit pamphlets of this period echoed similar themes, warning English Protestants of an internal Catholic plot. Within the early seventeenth century, events such as the 'Popish plot' as well as the Gunpowder plot would aggravate these concerns and lead to an increase in anti-Catholic literature. ${ }^{250}$

Marlowe's Doctor Faustus, as well The Jew of Malta and The Massacre of Paris all contained instances of anti-clericalism and Protestant nationalism. In Doctor Faustus, Marlowe depicts the clergy as superficial individuals who hide behind costumes, ceremony and materialism. In the Jew of Malta, he expands on these representations and portrays the clergy as spiritually corrupt in their pursuit of sexual and material pleasures. Echoing common portrayals of the clergy within medieval and early modern literature, Marlowe presents them as essentially powerless and comical figures. In Doctor Faustus, the pope's character and his conflict with the German emperor raise specific issues of monarchical authority and national Protestantism that were relevant in post-Reformation England. The pope is represented as a cruel character who poses a threat to the monarch's prerogative: a theme which comes through within the Globe Theatre's 2011 production of the play. Marlowe's Massacre at Paris elaborates on the tensions between Catholics and Protestants and speaks to sixteenth century fears of a Catholic rebellion in England.

\footnotetext{
${ }^{250}$ Marotti discusses this extensively in his work, paying special attention to the seventeenth century as a period when this literature flourished. Arthur F. Marotti, Religious Ideology and Cultural Fantasy: Catholic and Anti-Catholic Discourses in Early Modern England (Notre Dame: Notre Dame University Press, 2005).
} 
Through these representations, Marlowe is able to present Catholicism as spiritually absurd and powerless yet politically threatening and dangerous. 


\section{CHAPTER FOUR: Performing Religion in Doctor Faustus}

\subsection{Free Will and Predestination}

Much of the critical scholarship surrounding Doctor Faustus deals with the theological tensions within the play. The central issue is the nature of Faustus' damnation, and whether it was an act of free will or predestined to occur. Those who argue that it was an act of free will have examined the series of poor choices Faustus makes throughout the play as well as his failure to repent for his behaviour. Those who feel that the play reflects Calvinist notions of predestination emphasize the external forces which seem to guide Faustus to his ultimate damnation and argue that the choices he makes are due to his already doomed nature. The discussion of theology in Doctor Faustus reveals how many of the theological questions of the post-Reformation period made their way into Marlowe's text. During the Reformation in England, the state as well as individuals had to re-examine basic notions of theology and ask questions about the nature of grace and salvation. As the traditional beliefs and rites of purgatory and confession came to be discouraged by Protestant authorities, individuals may have felt an increased anxiety over the state of their spiritual wellbeing. ${ }^{251}$ As well, contemporary perceptions of theology were likely complicated by the numerous changes in official religious policy under the reigns of Edward VI, Mary I and Elizabeth I.

During the first years after the Elizabethan religious settlement, there was a shortage of qualified Protestant clergyman to administer to local communities. ${ }^{252}$ In the

${ }^{251}$ G.M Pinciss, "Marlowe's Cambridge Years and the Writing of Doctor Faustus," Studies in English Literature 33 (1993), 249.

${ }^{252}$ Norman Jones, "Religious Settlements" in A Companion to Tudor Britain, eds. Robert Tittler and Norman Jones (Malden, MA: Blackwell, 2004), 243. 
absence of a steady Protestant priesthood, individuals may have faced challenges interpreting matters of theology in scriptures that they encountered. Elizabeth's early religious policies emphasized conformity in practice more than they emphasized consistency in religious beliefs, and it is likely that traditional beliefs continued to persist in many communities. ${ }^{253}$ Calvinist ideas began making their way into England in the mid sixteenth century and debates about Calvinism and anti-Calvinism were popular in Cambridge in the 1580 s when Marlowe was a student there. ${ }^{254}$ Many of these ideas about predestination and providence would eventually become visible in doctrines of the established church, an example of which can be found in the Lambeth Articles of 1595 which states 'it is not placed in the will of power of everyman to be saved. ${ }^{, 255}$ The notion of predestination would have led to a "more direct confrontation between the individual sinner and his or her angry god."256 Much of the theological tensions and inconsistencies of this period would bleed into texts like Doctor Faustus. Efforts to understand the theology within the play reflect a desire to comprehend the anxieties that many sixteenth century individuals faced when confronting their spirituality.

Much of the language and dramatic action in Doctor Faustus make it seem as though Faustus' damnation stems from his inability to repent for the poor decisions he makes throughout the course of his twenty-four year pact with the devil. Certain phrases and actions suggest that he remains in control of his destiny and that the opportunity to repent is always open to him. His internal struggle with the idea of repentance is often

${ }^{253}$ Ibid., 243.

${ }^{254}$ Pinciss, "Marlowe's Cambridge Years," 249.

${ }^{255}$ Bevington and Ramussen, Doctor Faustus, 14. Predestination and providence were not only the concerns of Protestant thinkers. Walsham discusses how Catholic theologians also wrestled with these concepts before, throughout and after the Reformation. Alexandra Walsham, Providence in Early Modern England (New York: Oxford University Press, 1999).

${ }_{256}$ Ibid., 12-13. 
illustrated in his exchanges with the good and bad angels who are personifications of his crisis of conscience. Shortly after first making his pact with Mephistopheles, Faustus considers to himself, "Must though needs be damn'd? / Canst thou not be saved?" at which point the good and bad angels appear, with the good telling him that contrition, prayer and repentance remain open as "means to bring thee unto heaven." 257 In the next scene after Faustus has made his blood pact with Mephistopheles, the good angel reminds him "Faustus repent! Yet God will pity thee,"258 at which Faustus replies, "My heart is hardened, I cannot repent." 259 Faustus seems convinced that he cannot be saved, stating, "...whether should I fly? / If unto heaven / he'll throw me down to hell." ${ }^{260}$ It appears as though penitence is always open to Faustus, and his failure to do so is a result of his own conviction that he is too far gone to ever ask for forgiveness. The pride that first led to Faustus' ambitions for greatness prevents him from recognizing that he indeed has the ability to repent if he is humble and sincere in his contrition. His conviction early in the play that his actions are unforgiveable suggests that he has already given up and may be closed off to the Good Angel's offer of grace.

Though he rejects the Good Angel whenever he appears onstage, Faustus comes very close to repentance for a brief moment in Act II. After hearing the pleas of the Good Angel, he cries out "O Christ, my Savior, my Savior, / Help to save distressed Faustus' soul!" Lucifer then makes his first appearance onstage, reminding Faustus "Christ cannot

${ }^{257}$ B-text, 2.1: 390-391; 2.1:405-406.

${ }^{258}$ B-text, 2.3:12. The A-text reads, "Faustus, repent, yet, God will pity thee" which may indicate possible doubt about God's sympathy for Faustus.

${ }^{259}$ B-text, 2.3:18. The A-text reads, "My heart's so hardened I cannot repent" which suggests a slight hesitation whereas the B-text's "My heart is hardened" indicates a finality and assuredness of damnation. A-text 2.3:18.

${ }^{260}$ B-text, 2.1:77-78. This line appears as "If unto God" in the A-text. 
save thy soul, for he is just."261 Lucifer's appearance suggests that Faustus truly does have an opportunity to repent at this point. If it were too late to repent, then Lucifer would have no need to appear in this scene and distract Faustus with a show of the seven deadly sins.

In the final act of the play, the character of the Old Man appears to offer Faustus one of his last chances at salvation. He tells Faustus,

I see an angel hover o'er thy head And with a vial full of precious grace Offers to pour the same into thy soul Then call for mercy and avoid despair ${ }^{262}$

Faustus replies by stating "I do repent, and yet I do despair." At this point, Mephistopheles appears and Faustus requests that he bring about an apparition of Helen of Troy "whose sweet embraces may extinguish clear / those thoughts that do dissuade me from my vow/and keep my vow I made to Lucifer."263 In this scene, Faustus dismisses another chance to repent and instead chooses to be distracted by sexual love. As he approaches damnation in the final scenes of the play, his seems to want to repent, but remains convinced that he is too wicked to do so and unworthy of God's forgiveness. When his fellow scholars tell him in his final hour to "look unto heaven," he replies, "But Faustus offence can never be pardoned / The serpent that tempted Eve may be saved / But not Faustus." 264 As Paul Kocher writes, "the trouble with Faustus, then, is not that God withholds from him the grace necessary to repentance but that he himself refuses to make

\footnotetext{
${ }^{261}$ B-text, 2.3.83-85.

${ }^{262}$ B-text, 5.1.55-60.

${ }^{263}$ B-text, 5:1:89-90.

${ }^{264}$ B-text, 5.2:44-45.
} 
a real effort to accept it when it is offered."265 Critics who support the free will argument emphasize these instances where Faustus seems to make a conscious choice to not repent. His tragedy lies in his belief that he is too far gone to be saved which blinds him from the possibility of penitence when it is available to him. Therefore, Faustus is very much responsible for his fate and the end of the play. He consciously chooses to sin, makes a pact with the devil and though he wrestles internally with the idea of salvation, he never takes the steps necessary to change his behavior.

Though many of his adventures suggest that Faustus is responsible for his own damnation, there is a very Calvinistic undercurrent to much of the play. Scholars who have argued that Faustus' damnation was predestined to occur have examined the external forces within the play which specifically compel Faustus to sin. Within the prologue, the chorus speaks of Faustus' ambition: "His waxen wings did mount above his reach / And melting, heavens conspired his overthrow."266 The term 'conspired' may suggest that God and the Devil were working together to bring Faustus to his destiny; however, Marlowe may have selected the term 'conspired' simply because it metrically fits with the rhythm of the rest of the phrase. ${ }^{267}$ As well, the phrase which speaks of Faustus ambition seems to blame Faustus for his own downfall. As Tom McAlindon writes, "the causal process is first the sin of Icarian pride, and then divine punishment for that $\sin . " 268$ Though this phrase spoken by the chorus essentially remains ambiguous, it

${ }^{265}$ Paul Harold Kocher, Christopher Marlowe: a Study on his Thought, Learning and Character (New York: Russel, 1946), 110.

${ }^{266}$ Ibid., 21-22. 217.

${ }^{267}$ Thomas McAlindon, "Doctor Faustus: The Predestination Theory," English Studies 76 (1995), ${ }^{268}$ Ibid., 217-218. 
does suggest the possibility that Faustus' actions are not self-guided and that his choices reflect a larger plan over which he has little control.

Other phrases which have been cited as evidence for the Calvinism within Doctor Faustus include a line which Faustus speaks near the end of the play while he awaits his damnation. He blames fate for his situation, exclaiming that the stars whose "...influence hath allotted death and hell..." are responsible for his downfall. ${ }^{269}$ However, this phrase may not necessarily suggest that the fates encouraged Faustus' downfall; it simply reflects Faustus' character and his tendency to blame others for his actions. ${ }^{270}$ In the final act of the play, Mephistopheles himself claims that he was responsible for Faustus' initial exploration of magic, contributing to the notion that Faustus' actions were not completely acts of free will.

I do confess it, Faustus, and rejoice.

T'was I that, when thou wert I'the way to heaven, Damned up thy passage. When thou took'st the book

To view the scripture, then I turned the leaves And led thine eye. ${ }^{271}$

These phrases suggest that Faustus was victim to fate which was responsible for his disposition towards sin and therefore to blame for his damnation. This Calvinist message

${ }^{269}$ B-text, 5.2:160-161. Pinciss, "Marlowe's Cambridge Years," 258. Although he speaks several lines later "No Faustus, curse thyself. Curse Lucifer,/That hath deprived thee of the joys of heaven." By cursing himself, as well as Lucifer, Faustus may recognize his role in his damnation. Act5:2:182-183. As this does appear near the end of the play, it may just be a last ditch effort of a desperate man approaching damnation to blame others for his downfall.

${ }^{270}$ Sara Munson Deats, “'Mark this Show': Magic and Theatre in Marlowe's Dr. Faustus," in Placing the Plays of Christopher Marlowe, eds. Sara Munson Deats and Robert A. Logan (Aldershot: Ashgate, 2008).

${ }^{271} \mathrm{~B}$ text, 5.2:97-101. Though these lines suggest that Mephistopheles is to blame for Faustus actions, the Good Angel responds by stating, "O Faustus, if thou hadst given ear to me,/Inumerable joys had followed thee./But thou didst love the world" which once again implicates Faustus in his own downfall. B-text, 5.2.104-106. 
is strongest within the b-text version of the play than the a-text which omits this exchange entirely.

The b-text of Doctor Faustus is much more visual than the a-text, requiring greater theatrical effects such as smoke and fireworks, and often involving the presence of more characters on stage within any given scene. This is especially true of demons and devils who make several distinct appearances on-stage within the a-text. For example, when Faustus first performs his magic, the a-text provides the directions "enter Faustus to conjure" to which the b-text adds, "Thunder. Enter Lucifer and four devils" who keep watch over the ritual and Faustus' actions. In addition, the lines which Lucifer speaks alone within the a-text are often divided between him and his companion Beelzebub in the b-text which makes it seem as if there is more evil onstage shadowing Faustus. Barbara Howard Traister points out that the only good characters on stage, the Old Man and the Good Angel, are always balanced out by the presence of either the Bad Angel or Mephistopheles whenever they appear. However, the evil characters within the play such as Beelzebub, Lucifer and the nameless devils are constantly visible, often appearing in the b-text with drums or fireworks, and often without the presence of the good characters. $^{272}$ David Bevington argues that because there is a greater presence of evil onstage, the b-text has a "deterministic view of diabolical control," which emphasizes Faustus' role as a victim. ${ }^{273}$

\footnotetext{
${ }^{272}$ Barbara Howard Traister, Heavenly Necromancers: The Magician in English Renaissance Drama (Columbia: University of Missouri Press, 1984) 100.

${ }^{273}$ David Bevington, "One Hell of an Ending: Staging Last Judgement in the Townley Plays and in Doctor Faustus," in 'Bring Furth the Pageants: ' Essays in Early Modern English Drama presented to Alexandra F. Johnston, eds. David N. Klausner and Karen Sawyer Marsalek (Toronto: University of Toronto Press, 2007) 305. Though Bevington argues that it is the a-text which is more Calvinistic as "the btext seems comfortable with the notion that good works are a necessary and effacious step towards individual salvation." Leah Marcus agrees, stating that the B-text emphasizes outward forms and works and
} 
Readings of Doctor Faustus can therefore produce various theological interpretations of the play. These same theological ambiguities can also be complicated through performance. In the Globe production of Doctor Faustus, a particular gesture between the actors playing Faustus and Mephistopheles supports the argument which sees Faustus' sinning as an act of free will. After signing the deed to relinquish his soul to Satan, Faustus walks to the center of the stage where Mephistopheles is standing and holds out the paper signed in blood. ${ }^{274}$ Mephistopheles has his back to the audience and it therefore seems as if Faustus is presenting the deed, a tangible representation of his choices, to the audience members. Before Mephistopheles takes the deed, a moment of dramatic silence passes between the two actors who stare at each other and remain still. Mephistopheles then grabs the paper and begins to speak his respective lines. This dramatic pause gives the impression that Faustus has one more chance to truly think about what is taking place before he finalizes the pact. It also seems as if Mephistopheles is the one who is giving Faustus the opportunity to consider his actions before he goes further. This particular performance of the scene only reinforces the characterization of Faustus as a foolish and proud individual who does not realize the seriousness of his actions but who nevertheless makes a conscious and deliberate decision to sign over his fate.

Though this one small gesture which appears in the Globe production of Doctor Faustus supports the 'free will' argument of Faustus' damnation, other gestures within

therefore $\sin$ is incorrect action prompted by enemies outside the self whereas in the a-text, damnation remains a matter of inward conviction. Deats, "Mark this Show."

${ }^{274}$ In the $A$ and $B$ texts, after cutting into his arm, Faustus' blood congeals offering him a pause in which he can reconsider his actions and choose not to sign the deed. Mephistopheles moves off stage and returns with a torch to get Faustus blood to flow once again, solving this initial problem. The pause here remains significant in a 'free will' reading of the play as this is one of two opportunities in this scene for Faustus to turn away from evil before he makes his final pact. 
the play indicate that Faustus is indeed victim to the evil forces who seem to dominate the play. When Faustus questions Mephistopheles about God and the creation of the world, Mephistopheles chastises Faustus by grabbing his hand and shouting his lines at which point Faustus falls to the ground paralyzed by agony as if some great power has hold over him. The production also uses musical instruments at this point to make a dramatic and sinister sound. This seems to suggest that Faustus is victim to Mephistopheles, and possibly not strong enough to resist the evil forces within the play even if he tried. In the b-text, when Faustus has his last conversation with the Good and Bad Angels, no other figures are present onstage and Faustus is left alone to wrestle with his damnation. ${ }^{275}$ During the Globe performance of this scene, Mephistopheles remains in the background while Faustus speaks to the Good and Bad Angels, which disrupts the balance onstage and causes the scene to be dominated by evil characters against whom Faustus presumably remains powerless. As a result, the nuanced gestures used by the Globe production reflect the general theological ambiguity of the written versions of the play.

In both textual versions of Doctor Faustus, there is an often cited line which summarizes the theological ambiguity of the play. When Faustus argues with the two angels in the b-text, the Good Angel states that it is "Never too late, if Faustus will repent." In the a-text, the line reads "Never too late, if Faustus can repent."276 The btext's use of 'will repent' shifts the emphasis to Faustus' actions and suggests that penitence is a matter of choice whereas the a-text's 'can repent' makes it seem that salvation may be impossible if Faustus' will is indeed inherently corrupt. Overall, readings and performances of both the A and B texts led themselves to both 'free will'

\footnotetext{
${ }^{275}$ This exchange does not appear in the A-text.

${ }^{276}$ B-text, 2.3:79; A-text 2.3:79.
} 
and Calvinist interpretations of the play. Within Doctor Faustus, Marlowe engages with the questions of faith and salvation that many sixteenth century individuals would have struggled with. Without the aid of the traditional sacraments of the Catholic Church, many individuals may have struggled to find spiritual comfort in the post-Reformation period. Scholars including Martha Tuck Rozett, Pauline Honderich and Robert G. Hunter have ultimately found that Marlowe's true goal was not to provide any straightforward theological message in Doctor Faustus, but rather to exploit the same theological tensions that many contemporaries would have experienced during this time.

\subsection{Theatre, Religion and Magic: Performativity within Doctor Faustus}

In early modern England, theology was only one of several elements of religion undergoing significant changes. The rituals of worship associated with traditional religion were also being reformed and simplified in the post-Reformation period. Elaborate costumes and rituals were increasingly removed from churches as authorized and officially sanctioned iconoclasm challenged the validity of using material and visual objects in worship. This anxiety with the visual also manifested itself in many antitheatrical texts of this period. Doctor Faustus is a metadramatic work which brings attention to this anxiety with performance and visual representation that shares much if its vocabulary with anti-Catholic texts of this period. The play links theatre with magic and religion to make a commentary on the power of gestures, shows and ceremonies on-stage and within religious life. Overall, Doctor Faustus demonstrates that although shows and images can serve as distractions, they contain no inherent power and serve only as illusions. 
Early modern English society was full of pageantry and ceremony. Rituals and processions could have significant religious and secular importance to local communities. Music, gestures, costumes, and signs were used to create and convey shared meanings amongst individuals and help solidify social roles and identities. ${ }^{277}$ The Elizabethan theatre followed in this tradition and reflects a society that was already marked by an intense performativity. During the Reformation of the sixteenth century, the significance of these ceremonies and objects came into question. The logocentrism, iconoclasm and focus on inwardness that characterized many forms of Protestantism questioned the validity and power of representation within both religious and secular contexts. ${ }^{278}$ As a result, there was a level of discomfort with material visual representation in early modern England as individuals struggled to comprehend the full significance of these signs and symbols.

\subsection{Catholicism as Theatre}

Many anti-theatricalists of this period condemned the Elizabethan theatre because of this anxiety about material and visual representation. They claimed that the theatre encouraged worship of the visual and the material, and accused audience members of idolatry. Writers such as Anthony Munday and Philip Stubbes drew parallels between the theatre and the Catholic Church, claiming that the illusion created on stage was similar to

${ }^{277}$ David Bevington, Action is Eloquence: Shakespeare's Language of Gesture (Cambridge, Mass: Harvard University Press, 1984), 135. The performative nature of early modern English society is thoroughly discussed in Peter Lake and Michael Questier, eds. Anti-Christ's Lewd Hat: Protestants, Papists and Players in Post-Reformation England (Yale: Yale University Press, 2002).

${ }^{278}$ This is not to suggest that rituals and objects did not have a place within Protestant worship. As Alison Shell points out, "Many Protestants, mostly Lutherans, maintained religious ceremonial...". Alison Shell, Shakespeare and Religion (London: Methuen, 2010), 34. Nevertheless, there did exist an ambiguity when it came to objects with some Protestant groups recognizing their place in worship and others, such as Puritans, strongly against them. 
those that Catholics created through their worship. Like the Catholic Church, theatre allegedly used shows and objects to entrance and seduce individuals, leading them away from the spiritual reflection and self-examination encouraged by Protestantism. ${ }^{279}$ The associations between theatre and religion made sense in a culture where the ritualistic practice of traditional religion was so performative. With its processions and signs, the church itself was often "a stage for sacred performance." 280 The Reformation challenged the use of objects in traditional liturgy, as well as the alleged idolatry that many reformers viewed within churches.

Accusations of idolatry were also transferred to the theatre with the result that many anti-theatrical texts attacked the stage because of its visuality and materiality. In his 1580 A Second and Third Blast in Retreat from Plays and Theatres, Anthony Munday writes that "stage plays...were consecrated to the honor of heathen gods, therefore consecrated to idolatry." He writes explicitly of how "...shows and pomps are works of the devil."281 Similarly, in his 1582 Plays Confuted in Five Actions, Stephen Gosson accuses plays of being "inventions of the devil, the offerings of idolatry, the pomp of worldlings, [and] the blossoms of vanity...". ${ }^{282}$ John Greene also echoes these sentiments when he asks readers "what filthiness of idols should they more avoid then plays" in his 1615 A Refutation of the Apology for Actors. These tracts are indicative of an anxiety that existed with the visuality and representation that the theatre institutionalized. The spectacle of theatre, like that of Catholicism, was a distraction that drew attention to the

${ }^{279}$ Elizabeth Williamson, The Materiality of Religion in Early Modern English Drama (Surrey: Ashgate, 2009) 6.

${ }^{280}$ Ben R. McRee, "Traditional Religion," in A Companion to Tudor Britain, eds. Robert Tittler and Norman Jones (Malden, MA: Blackwell, 2004) 212.

${ }^{281}$ Anthony Munday, "A Second and Third Blast of Retreat from Plays and Theatres (1580)" in Shakespeare's Theater: A Sourcebook, ed. Tanya Pollard (Oxford: Blackwell Publishing, 2004) 67-84.

${ }^{282}$ Stephen Gosson, "Plays Confuted in Five Actions," in Shakespeare's Theater, 111. 
sensuality and illusory nature of the material world. If, according to these antitheatricalists, the medium of the theatre represented falsehood and idolatry, then what was the significance of performing religion onstage? Doctor Faustus makes considerable use of religious, often Catholic, gestures and objects onstage in order to reflect on the highly theological nature of the play. The symbolic significance of these gestures and objects varies throughout different scenes, but overall, Marlowe represents religion, particularly Catholicism, as being relatively powerless against the evil forces which Faustus encounters.

Marlowe takes advantage of the controversies surrounding theatre within Doctor Faustus by making several references to playing and show. The 'play within a play' was commonly used in many early modern works, allowing the playwright to reflect upon his own medium and explore the nature of theatricality. ${ }^{283}$ The repeated use of the terms 'show' and 'perform' in Doctor Faustus, the former of which occurs four times in the atext and five times within the b-text, is indicative of the metadramatic nature of the play. Tanya Pollard writes that these types of scenes help to "invite the audience to examine the relationship between the onstage spectators and ourselves; their reception of what they see offers a model for our own responses, and raises fundamental questions about the motives for, and consequences of, spectatorship." ${ }^{284}$ In Doctor Faustus, Marlowe uses playing and shows to raise issues about the power of visual representation. The medium of the theatre itself was a part of the effort to redefine the power of representation in the post-Reformation period and depictions of religious ceremony and rituals onstage became a significant part of this struggle.

\footnotetext{
${ }^{283}$ Shakespeare did this most famously within Hamlet, as well as A Midsummer Night's Dream and The Tempest.

${ }^{244}$ Pollard, Shakespeare's Theater: A Sourcebook, xviii.
} 
In Doctor Faustus, the function of shows and plays is to lure Faustus into evil and distract him from opportunities for repentance. This echoes the fears of many Protestant polemicists who accused Catholicism of doing the same. ${ }^{285}$ Distracted by the visual, Faustus continuously disregards the spiritual consequences of his actions and engages in sinful behaviour. One of the first examples of this occurs within the second act of the play when Faustus signs the deed which promises Mephistopheles his soul in exchange for magic. After he signs his name in blood, Faustus sees the inscription 'Homo Fuge' appear at which point he becomes nervous and starts questioning its spiritual significance. ${ }^{286}$ Alerted to his distress, Mephistopheles plans to "fetch him somewhat to delight his mind. ${ }^{, 287}$ According to the stage directions in both versions of the text, Mephistopheles returns with devils who dance about and give 'crowns and rich apparel' to Faustus. After they depart, Faustus asks Mephistopheles "What means this show?" to which Mephistopheles replies, "Nothing Faustus, but to delight thy mind / And to show thee what magic can perform". ${ }^{288}$ Only after being entranced by the show and the riches that the devils give him does Faustus submit his deed to Mephistopheles. In the Globe production of the play, after Faustus is given riches by the demons, he jumps up from his seat and hurriedly walks over to Mephistopheles to hand over the deed which suggests a strong connection between the material pleasures and visual spectacle offered by the demons and Faustus decision to finally give Mephistopheles the signed document.

\footnotetext{
${ }^{285}$ Arthur Marotti, Religious Ideology and Cultural Fantasy: Catholic and Anti-Catholic Discourses in Early Modern England (Notre Dame: University of Notre Dame Press, 2005 ).

${ }^{286}$ Homo fuge is a reference to the biblical 2 Timothy 6.11 and is one of several examples where Marlowe inverts Christianity throughout the text.

${ }^{287}$ A-text, 2.1:82.

${ }^{288}$ A-text, 2.1.83-84.
} 
Shortly after making his pact, Faustus begins to express some degree of regret and he entertains the possibility of repentance during a discussion with Mephistopheles about the creation of the world. After Mephistopheles commands Faustus to abandon thoughts of God, Faustus exclaims, "Ay, go, accursed spirit, to ugly hell! / Tis thou hast damned distressed Faustus' soul. / Is't not too late?" The good and bad angels then enter and Faustus wrestles with the question of whether or not salvation is possible. Mephistopheles slips off stage during this exchange, and returns with Lucifer and his demon companion, Beelzebub. Lucifer chastises Faustus for thinking about God, stating "Talk not of paradise nor creation, but mark this show." 289 At this point, Lucifer summons personifications of the seven deadly sins who dance about and introduce themselves, entertaining Faustus for the remainder of the scene. Afterwards, Lucifer asks Faustus if he enjoyed the show to which Faustus replies, "O, this feeds my soul." This scene demonstrates another instance within the play where Faustus begins to reflect upon himself and the spiritual decisions he has made only to be distracted by an intensely visual show.

The treatment of the seven deadly sins in Doctor Faustus can be interpreted in several important ways. Textually in both the A and B versions of the play, they are represented as serious characters who each arrive on stage one by one and explain their origins and purpose to Faustus. In performance however, these characters can be represented as profane symbols who should be laughed at. In the tradition of the morality play, the seven deadly sins were understood to be real threats to grace and salvation. ${ }^{290}$

${ }^{289}$ A-text, 2.3:75-105.

${ }^{290}$ The use of the seven deadly sins as personified characters in sixteenth century literature was not uncommon. They appear in Spenser's Farie Queene as well as in Richard Tarlton's The Seven Deadly Sins. 
Their representation within drama often reinforced their roles as warnings to audiences who should live pious lives and avoid sin. How the seven deadly sins were represented in performance and literature was relative to the religious and cultural environment from which these constructions were borrowed. The Reformation complicated the understanding of sin and vice; however, their role as spiritual warnings likely remained as a cultural legacy from the middle ages. ${ }^{291}$ In the Globe performance of Doctor Faustus, the sins are represented as comic figures. Dressed in black, they crawl onto stage and exhibit stereotypical behaviors consistent with their character. Faustus watches them while seated and laughs along with the audience. In the sixteenth century, the representation of the seven deadly sins may have had greater force if they were wearing any costumes or symbols associated with Catholicism. Autos Sacramentales has demonstrated that in seventeenth century Spanish plays, the seven deadly sins were often dressed as socially marginalized individuals and therefore functioned as symbols of otherness. ${ }^{292}$ In Elizabethan stagings of Doctor Faustus, it is possible that the actors playing the seven deadly sins dressed in recognizably Catholic garments therefore contributing to the negative representations of Catholics. As a result, the sins in Doctor Faustus could serve as evidence of Faustus' spiritual downfall and as warnings to audience members to avoid emulating his behavior. On the other hand, they could serve as figures of popular amusement and reflect Marlowe's general treatment of Christianity as profane and amusing. In this case, the sins function as an important reminder of how

${ }^{291}$ Richard Newhauser, ed., The Seven Deadly Sins: From Communities to Individuals (Boston: Brill, 2007).

${ }^{292}$ Autos Sacramentales, "Dressed to the Sevens, or Sin in Style: Fashion Statements by the Deadly Vinces in Spanish Baroque," in The Seven Deadly Sins: From Communities to Individuals, edited by Richard Newhauser (Boston: Brill, 2007). 
easily Faustus is distracted by show and how he is unable to recognize their presence as a warning for his behavior.

When Faustus visits Rome and mocks the Pope, he ceases to be a witness to the shows put on by the evil characters within the play and he instead becomes the protagonist. ${ }^{293}$ When first expressing his desire to travel to Rome, Faustus declares to Mephistopheles "Then in this show let me an actor be, / That this proud Pope may Faustus' cunning see." Mephistopheles responds by telling Faustus to think of "any villainy thou canst devise, / And I'll perform it...". ${ }^{294}$ The most elaborate show within the play is arguably that which occurs in Rome. The Pope's ceremonial entrance, elaborate costuming and eventual abuse at the hands of Faustus and Mephistopheles results in the most theatrical scene of the play. Faustus' and Mephistopheles' references to show and performance indicate a desire to participate in this act. They now become actors and Faustus particularly takes on the role of performer. Within this scene, several distinctly Catholic gestures and behaviours are performed which prove to be powerless and ineffective against the malevolence of Faustus and Mephistopheles.

The powerlessness of Catholic religious gestures is particularly evident during the Papal banquet scene. When Faustus first begins to harass the Pope, the stage directions of the text indicate that the Pope crosses himself. Within the a-text, Faustus responds to this by stating, "What, are you crossing yourself? Well, use that trick no more, I would advise you." The Pope then crosses himself twice more at which point Faustus punches him in the ear and then runs away. ${ }^{295}$ Within the b-text, this exchange goes a bit differently.

${ }^{293}$ This has significant implications for a 'free will' reading of the play as we now see Faustus as a direct participant in these actions.

294 These lines do not appear in the A-text.

295 A-text 3.1:77-80. 
After the first time the Pope crosses himself, Faustus remarks "How now? Must ever bit be spiced with a cross?" after which he observes the Pope crossing himself again and then proceeds to hit him in the head. ${ }^{296}$ In the post-Reformation period, making the sign of the cross was considered a superstitious and essentially powerless gesture which remained a relic of England's Catholic past. In his 1571 Injunctions for the Laity in the Province of York, protestant Archbishop Edmund Grindal attempted to remove all remnants of Catholic worship in York parishes writing, "no person or persons whatsoever... superstitiously shall make upon themselves the sign of the cross when they first enter into any church to pray...". ${ }^{297}$ In many Catholic contexts, making the sign of the cross continued to remain a symbol of faith and protection. To reforming Protestants, it was a symbol of Catholic superstition that was no longer useful in worship as a mark of grace. In this particular scene of Doctor Faustus, this sign is meaningless against Faustus' assaults, and is used to illustrate how the Pope has such little power that he cannot even protect himself against the antics of a magician. Furthermore, the character of the Pope is represented in a very unsympathetic and negative light and his use of this gesture could have caused audience members to associate the sign of the cross with the Pope's superficiality and falsehood.

Shortly after this exchange, the friars enter to perform their exorcism with "bell, book and candle." They chant their maledictions and lead a procession onstage during which Faustus and Mephistopheles fling fireworks at them and then exit the scene. It is unclear if Faustus leaves the scene as a result of the religious rituals, or because he had

${ }^{296}$ B-text 3.3:86.

297 "Archbishop Grindal's Injunctions for the laity in the province of York, 1571," in Religion and Society in Early Modern England: A Sourcebook, eds. David Cressy and Lori Anne Ferrell (New York; London: Routledge, 2005) 107. 
simply grown bored with his antics and decided to move onto something else. The feelings of boredom seem more consistent with Faustus' character and may explain his departure. In either case, the flinging of fireworks suggests that Faustus and Mephistopheles have little respect for the friars, and that they do not fear the gestures of exorcism. In this instance, the behaviour of the friars onstage can provide several different readings of this scene. If the actors playing the friars spoke their maledictions loudly with force, and created a large gestural space as they walked around stage performing this ritual, then their actions may have seemed powerful. On the other hand, if they seemed fearful and spoke quietly as if unsure of themselves, then their actions could hardly be taken seriously and audience members would question the power of their religious gestures. The behaviour of the friars during the scene demonstrates the powerlessness of the gestures and rituals that they were using to remove Faustus and Mephistopheles from the banquet hall. The bell, book, candles and holy water used by the friars are also implicated in this failed ritual, and therefore are also made powerless.

In the Globe production of this scene, the friars actually huddle together onstage and shake as they perform this ritual. They begin by moving in a circle but then break up their formation once the assault begins. One of them flings holy water and they all speak their lines in unison, though quietly and with quavering voices. Furthermore, as they perform these actions, Faustus and Mephistopheles pick up grapes from the banquet table and fling them at the friars who squeal and break up their formation. The actors playing Faustus and Mephistopheles react with mild amusement; Faustus especially smiles throughout the scene while Mephistopheles maintains a comparatively neutral expression. The friars within this scene are therefore represented as powerless and fearful characters. 
Their behaviour onstage only emphasizes their powerlessness as they themselves do not seem to believe their actions are especially effective. The audience in the Globe production laugh considerably throughout this scene at the friar's expense, especially when Faustus and Mephistopheles begin throwing grapes. Many of the gestures used by the friars within this scene such as the rites of exorcism, the use of holy water and the sign of the cross were all behaviours that the established church would reject in the later sixteenth and early seventeenth century. ${ }^{298}$

The metadramatic nature of Doctor Faustus allows Marlowe to explore the nature of theatricality and the power of representation within this play. When Faustus is the audience to a show, the performance serves as a visual and material distraction which corrupts his soul and prevents him from recognizing the full weight of his actions. Faustus' spiritual degeneration, which is aided by the idolatry he participates in, reflects what many sixteenth century anti-theatricalists feared about the stage. This same language of iconoclasm existed in many anti-Catholic texts of this period which often argued that Catholicism, like theatre, created illusions and encouraged worship of the visual. On the other hand, when Faustus himself is the performer, he demonstrates the powerlessness of religious show, revealing the emptiness of Catholic ritual and gesture. Faustus' treatment of the Pope and friars demystifies the power of their position and rituals. Faustus' experiences suggest that religious ceremonies and actions are entertaining yet essentially powerless. Visuality and ceremony have no inherent value, but can function as distractions. Through his exploration of the meanings of playing and show, Marlowe demonstrates how anti-Catholicism could reflect the larger debate about

${ }^{298}$ Keith Thomas, Religion and the Decline of Magic: Studies in Popular Beliefs in Sixteenth and Seventeenth-century England (London: Weidenfield and Nicolson, 1971), 265. 
the ambivalence and tension that existed with representation in post-Reformation England. Faustus role as magician and as a creator of his own visual illusions also complicates this discussion.

\subsection{Catholicism and Magic}

Faustus' exploration of magic allows him to create many of his own shows and acts which enables audiences to examine the relationship of magic to both theatricality and religion. Magic, theatre and religion are all performative activities involving a complex network of objects and gestures used to create and convey meaning. Some of Faustus' most memorable magical feats resemble religious practices. Ultimately however, these actions remain as powerless as the other shows he participates in throughout the play. The boundaries between magic and religion in the early modern period could be very permeable, as both practices relied on the belief that certain actions and rituals could invoke the supernatural intervention into daily life. The clergy in medieval England were often consulted because they were thought to possess special powers of healing and divination. Likewise, the rituals of conjurer's and magicians often resembled religious ceremonies and required the use of similar objects and materials. ${ }^{299}$ Although state and clerical attitudes towards magic became more critical during the Reformation period, it is likely that traditional folk practices and rituals continued to be practiced by local communities. ${ }^{300}$ Though opposition to magic preceded the Reformation, it was especially after the mid sixteenth century that England witnessed "a spectacular reduction in the 
power attributed to holy words and objects." ${ }^{301}$ Because of the fluidity between magical practices and popular religion, Catholic practices were often invoked in magical acts. For example, Latin prayers were commonly used for charms and Catholic symbols appeared regularly in magical rites. ${ }^{302}$ Polemicists of the sixteenth and seventeenth centuries often exploited these associations between Catholicism and magic in efforts to degrade both systems of belief. Keith Thomas in his influential work, Religion and the Decline of Magic, describes how recusant priests in Elizabethan England were often referred to as 'conjurers' in polemical works. A Puritan tract of this period went so far as to describe the Catholic Church as the source of "all wicked sorcery," and many other writers of this period attributed Catholic miracles to witchcraft. ${ }^{303}$

When Faustus first performs his conjuration, he inverts many religious signs and phrases in order to summon Mephistopheles, revealing a strong link between magic and religion. Faustus outlines a circle on the ground and writes in the names of Jehovah and several different saints. He then recites his spell in Latin and performs several distinctly Catholic behaviours like making the sign of the cross and sprinkling holy water. At one point he states, "By Jehovah, Gehenna, and this holy water which I now sprinkle, and the sign of the cross which I now make, and through our prayers, let Mephistopheles himself now rise up to speak to us." ${ }^{304}$ Performing these religious signs within this context of a conjuration may have had a very powerful effect on audiences who could have interpreted this ritual in several different ways. For those members of the audience who

${ }^{301}$ Ibid., 256.

${ }^{302}$ Ibid., 273. Nevertheless, it is problematic to suggest too close an association between Catholicism and magic as both Protestant and Catholics of the mid-sixteenth century were equally hostile to practices of popular magic.

${ }^{303}$ Ibid., 68-69.

304 The original Latin within the text is: "Jehovam, Gehennam, et consecratam aquam quam nunc spargo, signumque crucis quod nunc facio, et per vota nostra, ipse nuncsurgat nobis dicatus Mephistophilis." A-text, 1.3:16-23. 
still recognized the power of making the sign of the cross and sprinkling holy water, Faustus' actions would only reinforce his blasphemous nature and the evil of what he performs. However, individuals within the audience who saw these rituals as powerless and indicative of the superstitious nature of Catholicism may have instead used this scene to make an association between Catholic rituals and black magic. Faustus' use of Latin, which remained the official language of the Catholic Church, would have supported this notion. Although attitudes towards magic within this period were mixed, it is clear from the start of this ritual that Faustus' magic serves an evil purpose, and that his inversion of Catholicism during this unholy mass could convey an association between Catholic ritual and evil magic.

Faustus' conjuration is one of the most performative acts within the entire play. Aside from sprinkling holy water and making the sign of the cross, any actor playing Faustus has considerable autonomy in choreographing the character's movements onstage within this scene. In the Globe production, the actor playing the title character kneels before the circle he has created on the ground which seems to serve as an inverted altar in this ritual. Though it may seem insignificant, for some sixteenth century reformers, the act of kneeling was considered 'popish' and a ritual that needed to be removed from Protestant worship. Within the puritan 1572 document $A$ View of Popish Abuses yet Remaining in the English Church, reformists challenged the practice of kneeling when receiving communion partly because "it hath in it a show of papistry," but more so because the act of kneeling in front of anything suggested idolatry to which the composers of the document echoed the biblical commandment "Thou shalt not bow down 
to it, or worship it." ${ }^{305}$ Once again, the significance of this gesture remains vague within this scene. For any puritan-leaning sixteenth century audience members, a gesture such as this could strengthen the association between Faustus' magic and superstitious Catholic behaviour.

While kneeling during the conjuration, the actor playing Faustus removes a wooden crucifix he had been wearing around his neck and places it to the side before continuing his ritual. This behaviour does not occur in either textual version of the play and was the intention of the Globe company which raises significant possibilities for Elizabethan performances. Perhaps insignificant to modern audiences, if a sixteenth century actor possessed a crucifix during performance, it must have provided a range of reactions. Crucifixes, much like the rosary, had a strong correlation with Catholic worship. ${ }^{306}$ Faustus' removal of the crucifix in the middle of the conjuration may suggest that he himself is a Catholic. If this is indeed so, then his practice of dark magic could have the effect of reinforcing the association of between Catholicism and magic.

Furthermore, it could suggest that Catholics, who allegedly already possess a strong inclination for ritualistic behaviour, would be more likely to participate in a false, magical ceremony which would lead to sinful behaviour. ${ }^{307}$

Faustus' possession of the crucifix is indicative of how the use of objects also reveals contemporary tensions with the visual and material aspects of religion. For some audience members, the crucifix could pique an ongoing curiosity and possible reverence

305 "A View of Popish Abuses yet Remaining in the English Church," in Religion and Society in Early Modern England: A Sourcebook, eds. David Cressy and Lori Anne Ferrell (New York; London: Routledge, 2005), 82-89.

${ }^{306}$ McClain, Lest We Be Damned, 107-110.

${ }^{307}$ If Faustus is indeed a Catholic, this would have implications for the perception of his character as a 'Protestant hero' in the B-text of the play 
for the object-centered nature of Catholic worship. On the other hand, removed from their sacred contexts, the crucifix, as well as other religious objects, could be viewed as powerless because they have been transformed into commodifiable materials and made profane. $^{308}$ Elizabeth Williamson writes that in the use of religious materials on-stage, playing companies "were taking advantage of audience members' residual interest in the materiality of religion, revealing ongoing contradictions between post-Reformation theory and practice". ${ }^{309}$ In the case of Doctor Faustus, the only other explicitly religious materials used on-stage include the Papal crown as well as the bell, book, candles and holy water used by the friars. In the context of the power struggle between the rival popes, the crown represents the ambition and greed of Pope Adrian. The objects used by the friars prove to be useless as they do nothing to scare Faustus and Mephistopheles away during the exorcism. Generally, none of the religious objects used within the play possess any spiritual power.

After receiving his powers from Mephistopheles, much of the magic that Faustus performs is illusory and somewhat childish. He uses his magic to impress the Duke and Duchess of Vanholt, summoning apparitions and creating objects. As well, he creates horns on the head of the soldier Benvolio and then appears with a disembodied head when Benvolio and his friends attack him. ${ }^{310}$ Ironically, Faustus does not use his magic to achieve the knowledge, power and greatness that he initially desired but instead degrades himself performing tricks and illusions for whoever bears witness. One of the most significant shows that Faustus participates in is his summoning of Helen of Troy. After ignoring the pleas of the Old Man to repent, Faustus asks Mephistopheles to bring Helen

\footnotetext{
308 White, Theatre and Reformation, 34.

${ }^{309}$ Williamson, The Materiality of Religion, 5.

${ }^{310}$ The scenes with Benvolio and the soldiers do not appear in the A-text.
} 
of Troy as a distraction from his feelings of despair. Helen of Troy can be seen as an idolatrous figure within this scene whose beauty pulls Faustus away from the penitence offered by the Old Man. In spite of all of the tricks that Faustus is able to perform with his magic, he never truly becomes a powerful sorcerer. The comic scenes within the play illustrate the foolishness of Faustus' magic as the clowns Robin, Rafe and Dick, as well as the servant Wagner, "demonstrate how worthless his magic is by duplicating it." 311 Faustus' power, much like his tricks, is an illusion. In fact, many of the conjurations that Faustus seemingly performs are actually done by Mephistopheles. The apparitions of Helen of Troy as well as Alexander the Great summoned to impress the Duke and Duchess of Vanholt, are created by Mephistopheles who often remains in the background as Faustus takes the credit for his magic.

One could argue that the most powerful act Faustus performs is his conjuration of Mephistopheles at the beginning of the play. However, Mephistopheles confesses in the third act that he appeared to Faustus not because of the conjuration but because "when we hear one rack the name of God, / Abjure the Scriptures and his saviour Christ, / We fly in hope to get his glorious soul."312 The conjuration, in spite of its magical and religious undertones, is thus rendered effectively powerless. Once again, Faustus' powers are shown to be severely limited and even empty, as indeed are all the gestures and shows he participates in throughout the play. Anti-theatricalists feared the power of representation on-stage and Marlowe raises the possibility that all actions, both religious and magical, are essentially powerless. In Doctor Faustus, Marlowe engages with many of the religious controversies of the mid sixteenth century; theological tensions and the so-

\footnotetext{
${ }^{311}$ Traister, Heavenly Necromancers, 105.

${ }^{312}$ B-text, 1.3.45-47.
} 
called 'crisis of the image' that existed during this period informed his text. ${ }^{313}$ Faustus' misadventures and his eventual damnation contain many references to Catholic beliefs, gestures and practices. In the end, however, much of the plays central message remains ambiguous and its instances of anti-Catholicism only reflect much of the religious diversity and confusion that existed in post-Reformation England.

${ }^{313}$ 'Crisis of the image' refers to the term as it is used by O'Connell. Michael O'Connell, The Idolatrous Eye: Iconoclasm and Theatre in Early Modern England (New York: Oxford University Press, 2000). 


\section{CONCLUSION}

In post-Reformation England, there were numerous conflicts and tensions which surrounded questions of religious life and worship. Though the Elizabethan religious settlement was officially Protestant, debates about the extent of reform and the place of non-conformists in English society were far from over. During this period, there was a growing hostility towards English Catholics which in its greatest degrees led to restrictions on worship and legal persecution. The cultural context of this hostility can be seen in literature of this period which increasingly represented Catholics as cultural 'others' who should be socially and politically marginalized. A study of representations of Elizabethan Catholics reveals that these communities were portrayed as foreign, strange, rebellious and secretive. Catholic worship was represented as idolatrous and the clergy as spiritually powerless; yet paradoxically, Catholics were perceived as threatening and hostile to the stability of the English nation. In this context, the negative portrayal of Catholics in Christopher Marlowe's Doctor Faustus may have resonated with Elizabethan audiences whose experiences with contemporary religious controversies may have conditioned them to receive such representations as normative and therefore contributed further to anti-Catholicism in Elizabethan England. Furthermore Catholics themselves had to continue to live in a culture where these representations remained common. Any ongoing discussion about how Catholics lived their lives in postReformation England must consider how they may have dealt with such representations and what effect the discourse of anti-Catholicism may have had on their sense of themselves and their place in the world. 
The Elizabethan playhouses became spaces in which these religious and political controversies could be deconstructed and discussed through performance. Doctor Faustus was a play which remained popular throughout the 1590 s perhaps because it engaged with the religious tensions in this period. An analysis of its representation of Catholic theology within the play reveals that Faustus' struggle with the concepts of sin and redemption may have mirrored the experiences of Elizabethans who were coming to terms with the spiritual and doctrinal ambiguities and uncertainties introduced by the Reformation. In addition to theological tensions, Doctor Faustus raises issues about the visual and material nature of worship. The meta-theatrical nature of the play allows audiences to interrogate notions of 'idolatry' as well as the power of representation. In the play, the demystification of Catholic rituals and Faustus magic may be a commentary on debates about the spiritual power of the visual in post-Reformation society. This discussion is further complicated by the anti-theatrical discourse of this period which often attacked playgoers and actors for sharing the Catholic reverence for materiality and performance. What these tensions reveal is that there existed an anxiety about ceremony in worship and society after the Reformation in England.

The performable anti-Catholicism in Doctor Faustus can further be contextualized in the political challenges the Elizabethan government faced in this period. Hostility with Catholic Spain is referenced directly and alluded to in the play, and the parameters and consequences of Protestant nationalism are expanded on in Marlowe's The Massacre at Paris. In The Jew of Malta, Marlowe exaggerates the anti-clericalism he introduces in Doctor Faustus providing another important literary context for his overall artistic treatment of the Catholic clergy. The theological ambiguity, anti-clericalism and 
Protestant nationalism present in the A and B texts of Doctor Faustus are further complicated through performance. The two versions of play text itself remain fluid and open to numerous dramaturgical possibilities. The Globe performance of Doctor Faustus provides an important example of how this play can be staged and what actions and gestures actors can use to either exaggerate or diminish the anti-Catholicism of the text. An analysis of this performance revealed that the religious tensions and questions that exist in the play are not reconciled - and perhaps not reconcilable - onstage; instead, the Globe performance of Doctor Faustus mirrored the inherent ambiguity of the text. ${ }^{314}$ Though there are several notable instances of anti-Catholicism, they remain part of a larger discussion about the general anxiety surrounding questions of faith and worship in the Elizabethan period. How contemporary audiences would have engaged with these questions remains unclear and open to interpretation.

Audience members were direct participants in the representations of Catholics onstage. Their reactions to how Catholicism was performed may have impacted how future stagings of Doctor Faustus performed religion. Unlike modern audiences, Elizabethan playgoers were loud, boisterous and could comment on what they were experiencing while in the theatre. They could shout, heckle or laugh with certain actions and behaviors they saw onstage. ${ }^{315}$ This could help to shape future performances by the same acting company who may have altered their dramaturgy to appeal to what was most popular. As Patrice Pavis states, "Audiences are not simply intellectual, cerebral beings,

${ }^{314}$ Perhaps the spiritual questions raised by Doctor Faustus can be clarified and mediated through performance, presenting one or more coherent and consistent viewpoints. Whether or not this is possible depends on many factors such as how closely a theatre company follows either version of the play text, as well as whether or not a 'clear religious message' is a priority. The Globe performance however, intentionally or unintentionally, does not do so.

${ }^{315}$ Shell, Shakespeare and Religion, 74-77. 
they are also participants... [they are] reactive and affective." ${ }^{316}$ Their range of reactions impacted the social energy of the performance, and could have made the representations of Catholics onstage seem comedic, serious or profane.

After attending performances of Doctor Faustus, Elizabethan audiences could move to other social spaces such as nearby taverns and alehouses in order to talk about what they had seen onstage. Though the performance had ended, discussion surrounding what was experienced in these theatres was likely far from over. As William Prynne's 1633 reference to the devil in the play suggests, the frequency of performances of Doctor Faustus may have assured it a place in public memory. Although anti-Catholicism does appear in Doctor Faustus, it is difficult to assess what the effect of these representations were, and what remained at stake for audience members who were witness to the religious tensions present in, or caused by watching, these performances.

The instances of anti-Catholicism in Doctor Faustus could be interpreted in a variety of ways. These representations could have invoked feelings of fear, disgust, anger, embarrassment, humor, joy or complete apathy while the performance was taking place. These interpretations and initial reactions could shift once the performance was long over. After leaving the theatre, some audience members may have re-evaluated their 'gut feelings' about what they had seen. For others, any afterthoughts about the play may have reinforced initial emotional and intellectual reactions to the performance. It is important to recognize that the discourses about Catholics, Catholicism and antiCatholicism of which Doctor Faustus was part continued long after the staged aesthetic representations of religion were over. Marlowe's representations remained fluid, filled

\footnotetext{
${ }^{316}$ Pavis, Analyzing Performance, 229.
} 
with contradictions and paradoxes, and were newly contextualised with each performance.

The existence of anti-Catholic literature, sermons, and images provided an important cultural context for Marlowe's work and may have impacted how audiences interpreted what they saw on stage. The depictions of Catholics in other works of this period are likely to have informed the experiences of audience members who may have entered theatres with preconceived perceptions of Catholic life and worship. These works would have also shaped Marlowe's treatment of Catholics in his play, as well as the dramaturgical decisions made by actors during a performance. It is important to remember that Marlowe's work existed in the same cultural context as other representations of Catholics. Therefore, his text, the performances of his play and the reactions of audiences were all impacted by previous encounters with anti-Catholic thoughts and experiences. Unfortunately for historians, the full consequences of Marlowe's representations, conscious and unconscious remain inaccessible. It is difficult to assess how audiences dealt with what they witnessed as they could occupy many positions at any given time. Furthermore, it is problematic to assume that the representation of Catholics onstage impacted the social and political treatment of this group. Marlowe's work undoubtedly contributed to the ever changing treatment of religion on stage; however, it is impossible to make any strong conclusions about what happened to the issues raised by his work once they left the arena of the theatre and entered the Elizabethan social world. 


\section{BIBLIOGRAPHY}

\section{Primary Sources}

“Anonymous Journal, $19^{\text {th }}$ February to 10 April, 1593." Proceedings in the Parliaments of Elizabethan I, Vol. 3: 1593-1601. Edited by T.E. Hartley. Leicester: Leicester University Press, 1981.

"An Act against Jesuits, Seminary Priests and such other like disobedient persons." The Tudor Constitution: Documents and Commentary. Edited by G.R. Elton, 433-437. Cambridge: Cambridge University Press, 1960.

"An Act against Popish Recusants." The Tudor Constitution: Documents and Commentary. Edited by G.R. Elton, 437-442. Cambridge: Cambridge University Press, 1960.

Crosignani, Ginverva, Thomas M. McCoog, Michael Questier, and Peter Holmes, eds. Recusancy and conformity in early modern England: Manuscript and printed sources in translation. Toronto: Pontifical Institute of Medieval studies, 2010.

Foakes, R.A., ed. Henslowe's Diary. Cambridge: Cambridge University Press, 2002.

Gosson, Stephen. "Plays Confuted in Five Actions." In Shakespeare 's Theater: A Sourcebook, Edited by Tanya Pollard, 84-114. Oxford: Blackwell Publishing, 2004.

Lodge, Thomas. "A Reply to Stephen Gosson's School of Abuse, in Defence of Poetry, Music and Stage Plays." In Shakespeare's Theater: A Sourcebook. Edited by Tanya Pollard, 37-61. Oxford: Blackwell Publishing, 2004.

Heywood, Thomas. “An Apology for Actors.” In Shakespeare's Theater: A Sourcebook. Edited by Tanya Pollard, 213-254. Oxford: Blackwell Publishing, 2004.

Marlowe, Christopher. "The Massacre at Paris." In The plays of Christopher Marlowe, Edited by Roma Gill. London: Oxford University Press, 1971.

. Doctor Faustus. Edited by David Bevington and Eric Ramussen. Manchester: Manchester University Press, 1993.

. Doctor Faustus. Edited by W.W. Greg. Oxford: Clarendon Press, 1950.

The Jew of Malta. Edited by N.W. Bawcutt. Manchester: Manchester University Press, 1978.

The massacre at paris with the death of the Duke of Guise. Manuscript. London : Printed by E[dward] A[llde], 1594. From Early English Books Online 
1475-1640/ 815:10. Accessed November 14, 2010. http://eebointeractions.chadwyck.com/work/99845508.

.The famous tragedy of the rich Ievv of Malta As it vvas playd before the King and Queene, in his Majesties theatre at White-hall, by her Majesties Servants at the Cock-pit. Manuscript. London: Printed by I[onh] B[eale], 1633. From Early English Books Online 1475-1640/852:06. Accessed November 14, 2010. http://eebointeractions.chadwyck.com/work/99845496.

. The tragicall history of D. Faustus As it hath bene acted by the right honorable the Earle of Nottingham his seruants. London: Printed by V. S[immes], 1604. From Early English Books Online 1475-1640/ 894:08. Accessed November 14, 2010. http://eebo-interactions.chadwyck.com/work/99855372

Munday, Anthony. "A Second and Third Blast of Retreat from Plays and Theatre," in Shakespeare's Theater: A Sourcebook. Edited by Tanya Pollard, 62-83. Oxford: Blackwell Publishing, 2004.

"Sir Walter Mildmay's Speech for Supply." Proceedings in the Parliaments of Elizabethan I, Vol. 1: 1558-1581. Edited by T.E. Hartley. Leicester: Leicester University Press, 1981.

\section{Secondary Sources:}

Aveling, J.C. Catholic Recusancy in the City of York 1588-1791. London: Catholic Record Society, 1970.

Ashington, John. Actors and Acting in Shakespeare's Time: The Art of Stage Playing. Cambridge: Cambridge University Press, 2010.

Badir, Patricia and Paul Yachnin, eds. Shakespeare and The Cultures of Performance. Cornwall: Ashgate, 2008.

Bevington, David M. Action is Eloquence: Shakespeare's Language of Gesture. Cambridge, Mass: Harvard University Press, 1984.

. "Staging the A and B texts of Doctor Faustus." In Marlowe's Empery: Expanding his Critical Contexts. Edited by Sara Munson Deats and Robert A. Logan, 43-60. Newark: University of Delaware Press, 2002.

. "The Performance History." In Dr. Faustus: A Critical Guide, ed. Sara Munson Deats, 41-72. New York: Continuum, 2010.

Beauregard, David. Catholic theology in Shakespeare's plays. Newark: University of Delaware Press, 2008. 
Bentley, Gerald E. Profession of Player in Shakespeare's time, 1590-1642. Princeton: Princeton University Press, 1984.

Bossy, John. The English Catholic Community 1570-1850. London: Darton, Longman \& Todd, 1975.

Bradbrook, M.C. Themes and Conventions of Elizabethan Tragedy. Cambridge:

Cambridge University Press, 1980.

Brandt, Bruce E. "The Critical Backstory." In Dr. Faustus: A Critical Guide. Edited by Sara Munson Deats, 17-41. New York: Continuum, 2010.

Braunmuller, A.R. "The Arts of the Dramatist." In The Cambridge Companion to English Renaissance Drama. Edited by A.R. Braunmuller and Michael Hattaway, 53-90. New York: Cambridge University Press, 2003.

Briggs, Julia. "Marlowe's Massacre at Paris: A Reconsideration." Review of English Studies 34 (1983): 257-278, www.jstor.org/stable/517240 (accessed January 14, 2011).

Bryant, James C. Tudor Drama and Religious Controversy. Macon: Mercer, 1984.

Cartelli, Thomas. Marlowe, Shakespeare and the Economy of Theatrical Experience. Philadelphia: University of Pennsylvania Press, 1991.

Chedgzoy, Kate. "For Virgin Buildings oft Brought forth:' Fantasies of Convent Sexuality." In Female Communities, 1600-1800: Literary Visions and Cultural Realities. Edited by Rebecca D'Monte and Nicole Pohl, 53-75. New York: St. Martin's Press, 2000.

Clare, Janet. 'Art made tongue-tied by authority:' Elizabethan and Jacobean Dramatic Censorship. New York: Manchester University Press, 1990.

Cole, Douglas. Christopher Marlowe and the renaissance of tragedy. Wesport: Praeger, 1995.

Connelly, Roland. The Women of Catholic Resistance in England, 1540-1680. Edinburgh: Pentland Press, 1997.

Cook, Anna Jennalie. "Recent studies in Tudor and Stuart Drama." Studies in English Literature 39 (1999): 383-435. Accessed November 14, 2010. www.jstor.org/stable/1556171.

The Privileged Playgoers of Shakespeare's London 1576-1642.

Princeton: Princeton University Press, 1981. 
Cornelius, R.M. Christopher Marlowe's Use of The Bible. New York: Peter Lang Publishing, 1984.

Corthell, Ronald and Francis E. Dolan, Christopher Highly, Arthur F. Marotti, eds. Catholic Culture in Early Modern England. Notre Dame: University of Notre Dame Press, 2007.

Coursen, H.R. Shakespearean Performance as Interpretation. Newark: University of Delaware Press, 1992.

Covington, Sarah. The Trial of Martyrdom. Notre Dame: University of Notre Dame Press, 2003.

Crawford, Patricia. Women and Religion in England, 1500-1720. London: Routledge, 1993.

Crewe, Jonathan V. "The Theatre of the Idols: Theatrical and Anti-Theatrical Discourse." In Staging the Renaissance: Reinterpretations of Elizabethan and Jacobean Drama. Edited by David Scott Kastan and Peter Stallybrass, 49-56. New York: Routledge, 1991.

Dabbs, Thomas. Reforming Marlowe: The Nineteenth-century Canonization of a Renaissance Dramatist. Lewisburg: Bucknell University Press, 1991.

Davidson, Clifford. "Doctor Faustus at Rome." Studies in English Literature, 1500-1900 9:2 (1969): 231-239.

Davidson, Nicholas. "Christopher Marlowe and Atheism." In Christopher Marlowe and English Renaissance Culture. Edited by Darryl Grantley \& Peter Roberts, 129147. Aldershot: Scholar Press, 1996.

Deats, Sara Munson and Robert A. Logan, Eds. Marlowe's Empery: Expanding his Critical Contexts. Newark: University of Delaware Press, 2002.

Deats, Sara Munson. "Dido, Queen of Carthage, and The Massacre at Paris." In The Cambridge Companion to Christopher Marlowe. Edited by Patrick Cheney, 193207. Cambridge: Cambridge University Press, 2004.

"Mark this show": Magic and Theater in Marlowe's Doctor Faustus." In Placing the Plays of Christopher Marlowe. Edited by Robert Logan and Sara Munson Deats, 13-25. Aldershot: Ashgate, 2008.

Dean, David. Law-Making and Society in Late Elizabethan England. Cambridge: Cambridge University Press, 1996. 
Dessen, Alan. Elizabethan Stage Conventions and Modern Interpreters. New York: Cambridge University Press, 1984.

Dickens, A.G. "The Elizabethans and St. Bartholomew." In The Massacre of St. Bartholomew: Reappraisals and Documents. Edited by Alfred Soman, 471-490. The Hague: Nijoff, 1974.

Diefendorf, Barbara. The Saint Bartholomew's Day Massacre. Boston: Bedford, 2009.

Dillon, Anne. The Construction of Martyrdom in the English Catholic Community, 15351603. Aldershot: Ashgate, 2002.

Dolan, Francis. Whores of Babylon: Catholicism, Gender and Seventeenth-century Print Culture. Ithaca: Cornell University Press, 1999.

Dolan, Francis E. "Why are Nuns Funny?" Huntington Library Quarterly 70 (2007): 509-534.

Downie, J.A. "Marlowe: Facts and Fictions." In Constructing Christopher Marlowe. Edited by J.T Pamell and J.A Downie, 13-29. Cambridge: Cambridge University Press, 2000.

Duffy, Eamon. The Stripping of the Altars: Traditional Religion in England 1400-1580. New Haven: Yale University Press, 1992.

Duffy, Eamon. Fires of faith: Catholic England under Mary Tudor. New Haven: Yale University Press, 2009.

Duxfield, Andrew. "Modern Problems of Editing: The Two Texts of Marlowe's Doctor Faustus." Literary Compass 2 (2005): [no pagination].

Foakes, R.A. "Playhouses and Players." In The Cambridge Companion to English Renaissance Drama. Edited by A.R. Braunmuller and Michael Hattaway, 1-52. New York: Cambridge University Press, 2003.

Fox, Alistair. The English Renaissance: Identity and Representation in Elizabethan England. Oxford: Blackwell, 1997.

Freeman, Thomas S. "Joan of Contention: The Myth of the Female Pope in Early Modern England." In Religious Politics in Post-Reformation England. Edited by Kenneth Fincham and Peter Lake, 60-79. Woodbridge: Boydell Press, 2006.

Gallagher, Catherine and Stephen Greenblatt. Practicing New Historicism. Chicago: University of Chicago Press, 2000. 
Greenblatt, Stephen. Renaissance Self-fashioning. Chicago: University of Chicago Press, 1980. . Shakespearean Negotiations: The Circulation of Social Energy in Renaissance England. Oxford: Clarendon Press, 1990.

Gregory, Brad. Salvation at Stake: Christian Martyrdom in Early Modern Europe. Cambridge: Harvard University Press, 1999.

Guerin, Wilfred L. et al., A handbook of Critical Approaches to Literature. New York: Oxford University Press, 2005.

Gurr, Andrew and Maiko Ichikawa. Staging in Shakespeare's Theatres. Oxford: Oxford University Press, 2000.

Gurr, Andrew. Playgoing in Shakespeare's London. Cambridge: Cambridge University Press, 2004. . The Shakespearean Stage. Cambridge: Cambridge University Press, 1992.

Haigh, Christopher. English Reformation. Oxford: Clarenden Press, 1993. University Press, 1975. . Reformation and Resistance in Tudor Lancashire. London: Cambridge ."Catholicism in early modern England: Bossy and beyond." The Historical Journal 45 (2002):481-494. Accessed November 4, 2010. http://www.jstor.org.proxy.library.carleton.ca/stable/3133654

"From monopoly to minority: Catholicism in early modern England." Transactions of the Royal Historical Society 31 (1981):129-147. Accessed November 4, 2010. http://www.jstor.org.proxy.library.carleton.ca /stable/3679049

Hamlin, William H. "Misbelief, False Profession, and The Jew of Malta." In Placing the Plays of Christopher Marlowe. Edited by Robert Logan and Sara Munson Deats, 125-135. Aldershot: Ashgate, 2008.

Hattaway, Michael. "Drama and Society." In Cambridge Companion to English Renaissance Drama. Edited by A.R Braunmuller and Michael Hattaway, 43-130. Cambridge: Cambridge University Press, 2003. 1982. . Elizabethan Popular Theatre: Plays in Performance. London: Routledge, 
Hawthom, Jeremy. Cunning Passages: New Historicism, Cultural Materialism, and Marxism in the Contemporary Literary Debate. New York: St. Martin's Press, 1996.

Healy, Thomas. "Doctor Faustus." In The Cambridge Companion to Christopher Marlowe. Edited by Patrick Cheney, 174-192. New York: Cambridge University Press, 2004.

Healy, Thomas. New Latitudes: Theory and English Renaissance Literature. London: Routledge, 1992.

Heinemann, Margot. "Political Drama." In The Cambridge Companion to English Renaissance Drama. Edited by A.R. Braunmuller and Michael Hattaway, 161205. New York: Cambridge University Press, 2003.

Helgerson, Richard. Forms of Nationhood. Chicago: University of Chicago Press, 1992.

Hill, Christopher. Anti-Christ in Seventeenth-Century. London: Oxford University Press, 1971.

Hillman, David. Review of The Culture of Playgoing in Shakespeare's England: A Collaborative Debate by Anthony B. Dawson and Paul Yachnin. Shakespeare Quarterly 54 (2003): 207-209.

Hoover, Dwight W. "The New Historicism." The History Teacher 25 (1992): 355-366. Accessed January 29, 2011, www.jstor.org/stable/494247.

Howard, Jean E. "Women as Spectators, Spectacles, and Paying Customers." In Staging the Renaissance: Reinterpretations of Elizabethan and Jacobean Drama. Edited by David Scott Kastan \& Peter Stallybrass, 68-74. New York: Routledge, 1991.

Hyland, Peter. An Introduction to Shakespeare: The Dramatist in his Context. New York: St. Martin's Press, 1996.

Johnson, Alexandra F. "Tudor Drama, Theatre and Society." In A Companion to Tudor Britain. Edited by Robert Tittler and Norman Jones, 430-447. Malden: Blackwell Publishing, 2004.

Kaes, Anton. "New Historicism: Writing Literary History in the Post-modern Era." Monatshefte 84 (1992): 148-158. Accessed January 30, 2011, www.jstor.org/stable/30161347

Kastan, David Scott. Shakespeare After Theory. New York: Routledge, 1999.

Kelly, James E. "Kinship and religious politics among Catholic families in England, 1570-1640." History 94 (2009): 328-343. 
Kneidal, Gregory. Rethinking the Turn to Religion in Early Modern English literature. Hampshire: Palgrave Macmillan, 2008.

Kocher, Paul Harold. Christopher Marlowe: A Study of his Thought, Learning and Character. New York: Russell, 1946.

Kuriyama, Constance Brown. "Marlowe, Shakespeare and the Theoretically Irrelevant Author." In Placing the Plays of Christopher Marlowe. Edited by Sara Munson Deats and Robert Logan, 185-192. Aldershot: Ashgate, 2008.

Lake, Peter and Michael Questier, eds. Anti-Christ's Lewd Hat: Protestants, Papists and Players in Post-Reformation England. Yale: Yale University Press, 2002.

"Anti-popery: the structure of a prejudice," in Conflict in Early Stuart England: Studies in Religion and Politics. Edited by Richard Cust and Ann Hughes, 72-106. London: Longman, 1989.

Levin, Harry. The Overreacher: A Study of Christopher Marlowe. Cambridge: Harvard University Press, 1952.

Levine, Laura. Men in Women's Clothing: Anti-theatricality and Effeminization, 15791642. New York: Cambridge University Press, 1994.

Logan, Robert. "The State of the Art: Current Critical Research." In Dr. Faustus: $A$ Critical Guide, Edited by Sara Munson Deats, 72-95. New York: Continuum, 2010.

Lunney, Ruth. "Marlowe's Edward II and the Early Playhouse Audience." In Placing the Plays of Christopher Marlowe. Edited by Robert Logan and Sara Munson Deats, 25-42. Aldershot: Ashgate, 2008.

Lupton, Julia Reinhard. "The Jew of Malta." In The Cambridge Companion to Christopher Marlowe. Edited by Patrick Cheney, 144-157. Cambridge: Cambridge University Press, 2004.

Marotti, Arthur F. Religious Ideology and Cultural Fantasy: Catholic and Anti-Catholic Discourses in Early Modern England. Notre Dame: University of Notre Dame Press, 2005. . Catholicism and Anti-Catholicism in Early Modern English Texts. New York: St. Martin's Press, 1999.

MacDonald, Russ. "Marlowe and Style." In The Cambridge Companion to Christopher Marlowe, Edited by Patrick Cheney, 55-69. Cambridge: Cambridge University Press, 2004. 
MacIntyre, Jean. Costumes and Scripts in Elizabethan Theatre. Edmonton: University of Alberta Press, 1992.

Maguire, Laurie E. "Marlovian Texts and Authorship." In The Cambridge Companion to Christopher Marlowe, Edited by Patrick Cheney, 41-54. New York: Cambridge University Press, 2004.

McAdam, Ian. The Irony of Identity: Self and Imagination in the Drama of Christopher Marlowe. Newark: University of Delaware Press, 1999.

McAlindon, Thomas. Shakespeare Minus 'Theory.' Aldershot: Ashgate, 2004.

McClain, Lisa. 'Lest we be damned': Practical Innovation and Lived Experience among Catholics in Protestant England. New York: Routledge, 2004.

"Without Church, Cathedral or Shrine: The Search for Religious Space among Catholics of England, 1559-1625." The Sixteenth Century Journal 33 (2002): 381-399.

McDonald, Russ, ed. Shakespeare: An Anthology of Criticism and Theory, 1945-2000. Malden: Blackwell, 2004.

Monta, Susan Brietz. Martyrdom and Literature in Early Modern England. Cambridge: Cambridge University Press, 2005.

Montrose, Louis. The Purpose of Playing: Shakespeare and the Cultural Politics of the Elizabethan Theatre. Chicago: The University of Chicago Press, 1996.

Mullaney, Steven. The Place of the Stage: Licence, Play and Power in Renaissance England. Chicago: University of Chicago Press, 1998.

Nicholls, Charles. The Reckoning: The Murder of Christopher Marlowe. London: Jonathan Cape, 1992.

Nuttal, Geoffrey F. "The English Martyrs, 1535-1680: A Statistical Review." Journal of Ecclesiastical History 22 (1971): 190-197.

O'Connell, Michael. The Idolatrous Eye: Iconoclasm and Theatre in Early Modern England. New York: Oxford University Press, 2000.

O'Day, Rosemary. The Debate on the English Reformation. New York: Methuen, 1986.

Onions, C.T. A Shakespeare Glossary, Oxford: Clarendon Press, 1986. 
Orgel, Stephen. "What is a text?" In Staging the Renaissance: Reinterpretations of Elizabethan and Jacobean Drama, Edited by David Scott Kastan and Peter Stallybrass, 83-87. New York: Routledge, 1991.

Parker, John. "Barabas and Charles I." In Placing the Plays of Christopher Marlowe, eds. Robert Logan and Sara Munson Deats, 167-185. Aldershot: Ashgate, 2008.

Pavis, Patrice. Analyzing Performance: Theatre, Dance and Film. Translated by David Williams. Ann Arbor: University of Michigan Press, 2003.

Pendergast, John S. Religion, Allegory and Literacy in Early Modern England 15601640. Aldershot: Ashgate, 2006.

Performing the Queen's Men. "Play Texts and Stage Directions." Accessed January 9, 2011.http://tapor.mcmaster.ca/ thequeensmen/performance_research/traffic/block sethome.htm

Pettegree, Andrew. "A.G Dickens and His Critics: A New Narrative of the English Reformation." Historical Research (2004): 39-58.

Pinciss, G. M. "Marlowe's Cambridge Years and the Writing of Doctor Faustus." Studies in English Literature 33 (1993): 249-264.

Price, Roger. A Concise History of France. Cambridge: Cambridge University Press, 2005.

Pritchard, Arnold. Catholic Loyalism in Elizabethan England. Chapel Hill: University of North Carolina Press, 1979.

Probes, Christine McCall. "Rhetorical Strategies for a 'locus terribilis:' Senses, Signs, Symbols, and Theological Allusion in Marlowe's The Massacre at Paris." In Placing the Plays of Christopher Marlowe. Edited by Robert Logan and Sara Munson Deats, 149-166. Aldershot: Ashgate, 2008.

Pollard, Tanya. "Introduction." In Shakespeare's Theater: A Sourcebook. Edited by Tanya Pollard, x-xiv. Oxford: Blackwell Publishing, 2004.

Porter, Carolyn. "History and literature: After the new historicism." New Literary History 21 (1990): 253-272. Accessed November 20, 2010. www.jstor.org/stable/469250.

Potter, David. "Marlowe's Massacre at Paris and the Reputation of Henry III." In Christopher Marlowe and English Renaissance Culture. Edited by Darryl Grantley and Peter Roberts, 70-95. Aldershot: Scolar Press, 1996.

Questier, Michael. Catholicism and Community in Early Modern England. Cambridge: Cambridge University Press, 2006. 
."Practical anti-papistry during the reign of Elizabeth I." The Journal of British Studies 36 (1997): 371-396. (Accessed September 28, 2010), http://www.jstor.org.proxy.library.carleton.ca/stable/175891

Riggs, David. "Marlowe's Life." In The Cambridge Companion to Christopher Marlowe. Edited by Patrick Cheney, 24-40. Cambridge: Cambridge University Press, 2004.

Rokem, Freddie. Performing History: Theatrical Representations of the Past in Contemporary Theatre. Iowa City: University of Iowa Press, 2000.

Rowse, A.L. Tudor Cornwall: Portrait of a Society. London: Macmillan, 1969.

Scarisbrick, J.J., The Reformation and the English People. New York: Blackwell, 1984.

Scott-Warren, Jason. Early modern English literature. Cambridge: Polity Press, 2005.

Shagan, Ethan, ed. Catholics and the 'Protestant Nation'. Manchester: Manchester University Press, 2005.

Shell, Alison. Catholicism, Controversy and the English Literary Imagination, 15581660. Cambridge: Cambridge University Press, 1999.

Simkin, Stevie. Marlowe: The Plays. Houndmills: Palgrave, 2001.

Smith, Emma. The Cambridge Introduction to Shakespeare. New York: Cambridge University Press, 2007.

Tennenhouse, Leanord. "Playing and Power." In Staging the Renaissance: Reinterpretations of Elizabethan and Jacobean Drama. Edited by David Scott Kastan and Peter Stallybrass, 27-39. New York: Routledge, 1991.

Thomas, Vivien and William Tydeman, eds. Christopher Marlowe: The Plays and Their Sources. London: Routledge, 1994.

Vidmar, John, English Catholic Historians and the English Reformation, 1585-1954. Brighton: Sussex Academy Press, 2004.

Veenstra, Jan R. "The New Historicism of Stephen Greenblatt: On poetics of Culture and the Interpretation of Shakespeare." History and Theory 34 (1995): 174-198. Accessed November 20, 2010, www.jstory.org/stable/2505620.

Veeser, H. Aram. The New Historicism. New York: Routledge, 1989.

Walsham, Alexandra. Church Papists. Woodbridge: The Boydell Press, 1999. 
.Domme Preachers: Post-reformation English Catholicism and the Culture of Print." Past \& Present 68 (2000): 72-123. Accessed September 28, 2010, http://www.jstor.org. proxy.library.carleton.ca/stable/651306.

. "Unclasping the Book: Post-reformation English Catholicism and the vernacular bible." The Journal of British Studies 42 (2003): 141-166. Accessed September 28, 2010. http://www.jstor.org.proxy.library.carleton.ca/stable/3594905. Press, 1999.

Watson, Robert N. "Tragedy." In The Cambridge Companion to English Renaissance Drama. Edited by A.R. Braunmuller \& Michael Hattaway, 301-351. New York: Cambridge University Press, 2003.

Watt, Tessa. Cheap Print and Popular Piety, 1550-1640. New York: Cambridge University Press, 1991.

Watt, S.J. From Border to Middle Shire: Northumberland 1586-1625. Leicester: Leicester University Press, 1975.

White, Paul Whitfield. Theatre and Reformation: Protestantism, Patronage and Playing in Tudor England. Cambridge: Cambridge University Press, 1993. . "Marlowe and the Politics of Religion." In The Cambridge Companion to Christopher Marlowe. Edited by Patrick Cheney, 70-89. Cambridge: Cambridge University Press, 2004.

Williamson, Elizabeth. The Materiality of Religion in Early Modern English Drama. Burlington. VT: Ashgate, 2009.

Wilson, Richard. “'Writ In Blood': Marlowe and the new historicists." In Constructing Christopher Marlowe. Edited by J.T Parnell and J.A Downie, 116-132. Cambridge: Cambridge University Press, 2000.

Wizeman, William. The Theology and Spirituality of Mary Tudor's Church. Burlington: Ashgate Publishing Company, 2006.

Worthen, William B. "Deeper Meanings and Theatrical Technique: The Rhetoric of Performance Criticism." In Shakespeare: An anthology of criticism and theory, 1945-2000. Edited by Russ McDonald, 762-776. Malden: Blackwell, 2004.

Zlater, Antoinina Bevan. Reformation Fictions: Polemical Protestant Dialogues in Elizabethan England. New York: Oxford University Press, 2011. 